\title{
ARTICLES
}

\section{MODELING FRIVOLOUS SUITS}

\author{
ROBERT G. BONE† \\ TABLE OF CONTENTS
}

INTRODUCTION

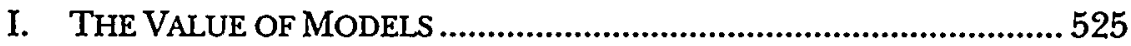

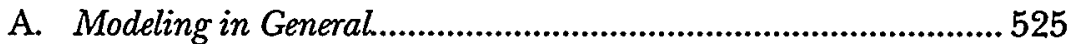

B. Modeling Frivolous Litigation.................................................... 527

II. DEFINING "FRIVOLOUS SUITS" ................................................529

III. POSITTVE EXPECTED VALUE MODELS ...........................................534

IV. NEGATTVE EXPECTED VALUE MODELS:

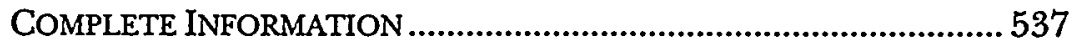

V. NEGATIVE EXPECTED VALUE MODELS:

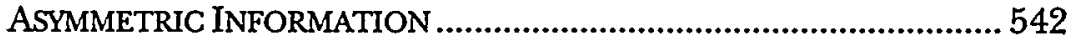

A. The Informed-Plaintiff Model................................................542

1. A Simple Narrative: John v. Mary ..................................543

2. The Formal Model and Its Predictions .........................547

B. The Informed-Defendant Model..................................................550

1. A Simple Narrative: Paul v. Susan.................................550

a. Scenario \#1-Investigation Costs $\$ 100$......................553

b. Scenario \#2-Investigation Costs $\$ 5000$.................... 554

c. Scenario \#3-Investigation Costs $\$ 2000$.................... 556

2. The Formal Model and Its Predictions ........................ 559

3. Defining a "Reasonable" Prefiling Investigation ............ 564

C. Reliability of the Asymmetric Information Models.........................566

1. Internal Assumptions .....................................................567

2. External Factors..........................................................571

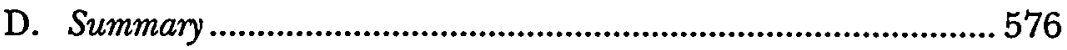

† Professor of Law, Boston University School of Law. I wish to thank all those who participated in faculty workshops on this paper held at Rutgers-Camden School of Law and Boston University School of Law. I am especially grateful for helpful comments from Joe Brodley, Ron Cass, Keith Hylton, Lauren Robel, Anne-Marie Slaughter, Allan Stein and Carl Tobias. My research assistants, Adena Abramowitz, Traci Vanek and Patricia Washienko also provided invaluable assistance. Finally, I would like to express my thanks for support from the George Michaels Faculty Research Fund. 


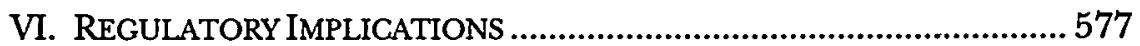

A. Is Any Public Regulation Desirable?........................................579

1. The Seriousness of the Problem....................................579

2. The Need for a General Norm .....................................580

B. Targeted Versus Uniform Enforcement ......................................583

C. The Selection of an Enforcement Device........................................586

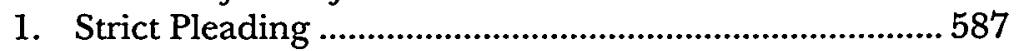

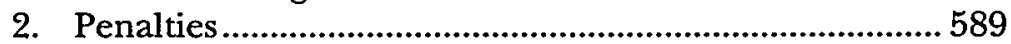

3. A More Promising Approach: Judicial Screening..........593

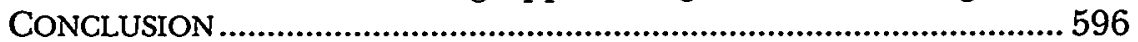

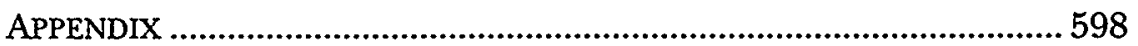

\section{INTRODUCTION}

We know remarkably little about frivolous litigation. Reliable empirical data is extremely limited, and casual anecdotal evidence highly unreliable. We have no clear explanation of why frivolous suits are filed or even common agreement on what constitutes a "frivolous suit."

Nevertheiess, there is widespread belief that frivolous litigation is out of control. ' Many people cite frivolous suits as the cause of the litigation system's most serious ills-huge case backlogs, long delays and high trial costs. ${ }^{2}$ Americans are simply too litigious, the critics

1 See Walter $\mathrm{K}$ Olson, The litigation Explosion: What Happened When AMERICA UNLEASHED THE LAWSUIT 247-70 (1991) (discussing examples of frivolous litigation); INSURANCE INFO. INST., ATTITUDES TOWARD THE LIABILITY AND LITIGATION SYSTEM 17 (1982) (Gallup survey reporting that $31 \%$ of the general public perceives lawsuits as justified "less than half of the time" and $41 \%$ perceives lawsuits as justified "about half of the time"); Valerie P. Hans \& William S. Lofquist, Jurors' Judgments of Business Liability in Tort Cases: Implications for the Litigation Explosion Debate, 26 L. \& SOC'Y REV. 85, 96 (1992) (noting that research revealed "a widespread impression among jurors that the civil litigation system is overburdened by claimants seeking awards in meritless cases"); What America Really Thinks About Lawyers, NAT'L L.J., Aug. 18,1986 , at S-1, S-3, S-8 (reporting the results of a poll on how Americans feel about lawyers and their role in the "litigation explosion" that has led to the so-called liability and medical malpractice crises); see also Scott S. Partridge et al., A Complaint Based on Rumors: Countering Frivolous Litigation, 31 LOY. L. REV. 221, 233-34 (1985) (recounting popular anecdotes of frivolous litigation).

2 See, e.g., PRESIDENT's COUNCIL ON COMPETITIVENESS, Agenda FOR CIVIL Justice REFORM IN AMERICA 1-3, 8-9 (1991) (describing the high costs of unrestrained litigation); NEW YORK STATE BAR ASS'N, REPORT OF THE SPECIAL COMMITTEE TO CONSIDER SANCTIONS FOR FRIVOLOUS LITIGATION IN NEW YORK STATE COURTS (Mar. 20, 1990), reprinted in 18 FORDHAM URB. L.J. 3 (1990) (discussing New York's legislative efforts to deal with frivolous litigation and proposing reforms); Warren E. Burger, The State of Justice, A.B.A. J., Apr. 1984, at 62, 65 (commenting on the growing abuse of discovery); 


\section{say, and all too fond of filing meritless suits. ${ }^{3}$}

Indeed, concern about frivolous litigation has inspired some of the most significant procedural developments of the past two decades. During the 1980s, for example, federal courts tightened pleading requirements in areas such as civil rights, antitrust and shareholder derivative litigation in an effort to screen out frivolous suits. ${ }^{4}$ In 1983, the Advisory Committee on Civil Rules overhauled Rule 11 of the Federal Rules of Civil Procedure to strengthen sanctions for frivolous filings. ${ }^{5}$ And in a trilogy of cases decided during the 1985 term, the Supreme Court broadened the availability of summary judgment in part to weed out frivolous cases before trial. ${ }^{6}$

Wesley A. Cann, Jr., Frivolous Lawusuits-The Lawyer's Duty to Say "No," 52 U. COLO. L. REV. 367, 367 (1981) ("[T]he 'sue the bastard' mentality has helped create the 'frivolous' lawsuit with all its undesirable baggage-undue harassment, both personal and monetary, clogging of the judicial machinery, and mistrust of the legal system in general and lawyers in particular."); Partridge et al., supra note 1, at 232-35 (describing the adverse impact of frivolous litigation); John W. Wade, On Frivolous Litigation: $A$ Study of Tort Liability and Procedural Sanctions, 14 HOFSTRA L. REV. 433, 436 \& n.8 (1986) (arguing that frivolous litigation has greatly added to court clogging and public exasperation).

${ }^{3}$ People often collapse what are in fact quite distinct complaints, one about excessive litigation and the other about abusive litigation. For a critique of the claim that America has become more litigious in recent decades, see Marc Galanter, Reading the Landscape of Disputes: What We Know and Don't Know (and Think We Know) About Our Allegedly Contentious and Litigious Society, 31 UCLA L. REV. 4 (1983). For a discussion of the problems in defining frivolous suits, see infra Part II.

See, e.g., Richard L. Marcus, The Revival of Fact Pleading Under the Federal Rules of Civil Procedure, 86 Colum. L. REv. 433, 447-51 (1986) (arguing that despite the Supreme Court's statements regarding notice pleading, in practice, federal courts insist on detailed factual allegations in antitrust, civil rights and securities fraud cases). In 1993, the Supreme Court stopped this trend by holding that the Federal Rules of Civil Procedure required a liberal pleading approach. See Leatherman v. Tarrant County Narcotics Intelligence \& Coordination Unit, 507 U.S. 163, 164 (1993) (rejecting the Fifth Circuit's heightened pleading standard for civil rights cases). Still, some federal courts continue to require specificity despite Leatherman. See Branch v. Tunnell, 14 F.3d 449, 455-57 (9th Cir. 1994) (applying heightened pleading requirement to a Bivens action against an individual government agent); Storer Cable Communications, Inc. v. City of Montgomery, 826 F. Supp. 1338, 1347 (M.D. Ala. 1993) (holding that even with liberal pleading requirements, the plaintiff must still plead sufficient facts so that each element of an alleged antitrust violation can be identified); Karen M. Blum, Heightened Pleading: Is There Life After Leatherman?, 44 CATH. U. L. REV. 59, 75-87 (1994) (surveying post-Leatherman case law on heightened pleading requirements).

5 See FED. R. CIV. P. 11 advisory committee's note (1983) (referring to the goals of discouraging dilatory or abusive tactics and lessening frivolous claims or defenses). The Advisory Committee amended Rule 11 again in 1993 to soften its impact, but deterrence of frivolous litigation remains its chief purpose. See FED. R. CIV. P. 11 advisory committee's note (1993).

${ }^{6}$ See Celotex Corp. v. Catrett, 477 U.S. 317, 322-25, 327 (1986); Anderson v. Lib- 
More recently, during the 1994 campaign, Republican candidates for Congress highlighted abusive litigation in their "Contract With America." After the election, the Republican Congress entertained several bills designed to deter frivolous suits. ${ }^{8}$ In December 1995, one of those bills, the Private Securities Litigation Reform Act of 1995, became law over Presidential veto. Later, in April 1996, the Prison Litigation Reform Act of $1995,{ }^{10}$ designed to deter frivolous prisoner suits, also became law. ${ }^{11}$

This combination of informational deficit and regulatory zeal is fraught with obvious danger. We cannot make sound policy on the basis of anecdote and conjecture. We need a much more reliable basis for predicting costs and benefits. And for this, we need a positive theory of frivolous litigation. To be useful, however, such a theory must answer an apparently simple, yet surprisingly difficult, question: Why would anyone ever file a frivolous suit? If a suit lacks merit and has very little chance of trial success, no rational person would spend thousands of dollars to try the case. To be sure, a plaintiff might sue if he thought he could obtain an early settlement. But this raises another, equally vexing question: Why would a defendant ever settle if he knows the plaintiff would never litigate; why not simply call the plaintiff's bluff instead?

This Article constructs a positive theory of frivolous litigation capable of answering these questions, and then examines the policy implications for regulating frivolous suits. ${ }^{12}$ Because reliable data is

erty Lobby, Inc., 477 U.S. 242, 255 (1986); Matsushita Elec. Indus. Co. v. Zenith Radio Corp., 475 U.S. 574, 585-88, 597 (1986).

CONTRACT WITH AMERICA: THE BOLD PLAN BY REP. NEWT GINGRICH, REP. DICK ARMEY, AND THE HOUSE REPUBLICANS TO CHANGE THE NATION 143-55 (Ed Gillespie \& Bob Schellhas eds., 1994) (arguing that frivolous lawsuits make a mockery of the American justice system and offering various "common sense legal reforms" to solve the problem).

See, e.g., Common Sense Legal Standards Reform Act, H.R. 956, 104th Cong. (1996) (implementing measures, including punitive damage caps, for controlling products liability cases); Attorney Accountability Act, H.R. 988, 104th Cong. (1995) (adopting two-way conditional fee shifting and stricter Rule 11 sanctions); Private Securities Litigation Reform Act, H.R. 1058, 104th Cong. (1995) (prescribing limits on private actions for securities fraud).

${ }^{9}$ Pub. L. No. 104-67, 109 Stat. 737.

${ }^{10}$ Pub. L. No. 104-134, $\S \S 801-10,110$ Stat. 1321, 1321-66 to 1321-77 (1996).

"Moreover, congressional enthusiasm for reform has inspired similar efforts at the state level. See, e.g., Doris S. Wong, Tort Reform Unveiled by Weld: Critics Contend Plan Unfair to Consumers, BOSTON GLOBE, June 29, 1995, at 27 (reporting on a Massachusetts bill similar to congressional tort reform legislation).

${ }^{12}$ I focus on frivolous suits and ignore other kinds of frivolous litigation activity, 
scarce and obstacles to empirical work severe, I focus on a body of work by law-and-economics scholars that uses game-theoretic models to study the frivolous suit problem. I translate this work for a nontechnical audience and show how its insights can be useful in shaping regulatory policy.

In addition, I present a new model that fills a gap in the literature. Most work to date focuses on so-called "strike suits"-cases in which a plaintiff files knowing her suit is frivolous. No one has yet developed a model that shows what happens when a plaintiff files suit ignorant of the merits because she has not investigated. ${ }^{13}$ This is a significant omission, since cases of this sort comprise much of what people consider frivolous. Indeed, the most important innovation of the 1983 version of Rule 11, carried forward in the 1993 revision, ${ }^{14}$ requires parties to conduct a reasonable prefiling inquiry. ${ }^{15} \mathrm{My}$ new model explains why plaintiffs might not investigate before filing even when investigation is feasible, and this explanation provides a framework for the later policy analysis.

At the most general level, this Article aims to bridge the wide gap between lawyer-economists who use game-theoretic techniques to model procedural rules, and mainstream proceduralists, lawyers and judges who make, apply and critique those rules. ${ }^{16}$ Game theory is ex-

such as defenses, motions and discovery requests. There is evidence that frivolous suits pose the most serious problem. See THOMAS E. WILIGING, THE RULE 11 SANCTIONING PROCESS 78 tbl.12 (1988) (reporting that over one-half of cases under 1983 Rule 11 involved the filing of an unjustified complaint); Lawrence C. Marshall et al., The Use and Impact of Rule 11, 86 Nw. U. L. REV. 943, 953 (1992) (finding, in a survey of Rule 11 activity among lawyers, that "the most common reason for actual sanctions, as well as for motions and show cause orders, is the filing of allegedly frivolous suits or claims").

${ }^{13}$ Professor Nalebuff has developed a model in which an uninformed plaintiff files suit and offers a settlement to an informed defendant. See Barry Nalebuff, Credible Pretrial Negotiation, 18 RAND J. ECON. 198, 198-209 (1987). Because it does not include investigation, however, Nalebuff's model cannot explain why plaintiffs choose to remain uninformed.

${ }^{14}$ See FED. R. CIV. P. 11(b) (1993).

13 See FED. R. Crv. P. 11 \& advisory committee's note (1983); see also Marshall et al., supra note 12, at $947-48$ (noting that the 1983 and 1993 versions of Rule 11 instructed judges to look into what an attorney should have known about the law and facts of a case after conducting a reasonable prefiling inquiry).

${ }^{16}$ Economists who do game-theoretic work in litigation tend to write for technical audiences ard publish mainly in specialized journals beyond the reach of most lawyers, judges and legal academics interested in procedural reform. By the same token, proceduralists tend to shun game-theoretic models partly because of their mathematical technicality, partly because of doubts about their utility, and partly because of a mistaken impression that they conceal a conservative political agenda or a morally 
tremely useful to procedural analysis because it is the best, and perhaps the only, systematic way to analyze strategic interaction essential to predicting litigation behavior. ${ }^{17}$ Fortunately, the basic insights of game theory do not require technical sophistication, and this Article avoids mathematical technicality by explaining the models with simple expository narratives that show how strategically motivated parties might think through their choices and decide what to do. The Appendix summarizes the mathematical results for interested readers.

The main body of this Article is divided into six parts. Part I briefly examines the importance of formal modeling to procedural analysis in general and to the regulation of frivolous suits in particular. Part II explores the difficulties in defining a "frivolous suit" and proposes a working definition for the remainder of the Article.

Part III reviews standard models of frivolous litigation that assume frivolous suits have positive expected value and argues that none is robust enough to predict a serious frivolous suit problem. Parts IV and $V$ then examine a more promising class of models: those that suppose frivolous suits have negative expected value. One type, which is discussed in Part IV, assumes complete information-both parties know whether a suit lacks merit. The other type, which is discussed in Part V, assumes asymmetric information-one party knows but the other does not.

As it turns out, complete information models provide only a weak explanation of frivolous suits. Frivolous litigation is most likely to occur under conditions of asymmetric information. Part $V$ examines two different asymmetric information models. It first describes current models that assume the plaintiff knows her suit is frivolous and the defendant does not, and then turns to my new model, which explains frivolous filings when the asymmetry runs in the opposite

questionable account of human behavior. For an accessible survey of the many applications of game theory to law, see generally DOUGLAS G. BAIRD ET AL., GAME THEORY AND THE LAW (1994).

${ }^{17}$ For a few examples of game-theoretic insights, see Avery Katz, The Effect of Frivolous Suits on the Settlement of Litigation, 10 INT'L REV. L. \& ECON. 3 (1990) (predicting that increasing filing costs will not deter frivolous suits); D. Rosenberg \& S. Shavell, $A$ Model in Which Suits Are Brought for Their Nuisance Value, 5 INT'L REV. L. \& ECON. 3 (1985) (predicting that plaintiffs might still file frivolous suits even when they know defendants are aware that the suits are frivolous); Steven Shavell, Sharing of Information Prior to Settlement or Litigation, 20 RAND J. ECON. 183 (1989) (predicting that defendants might voluntarily disclose incriminating information without the need for mandatory discovery). 
direction-defendant knows and plaintiff does not unless she investigates. In this new model, plaintiffs sometimes sue without investigating even when they have ample time, the cost is moderate, and they know that frivolous suits always lose at trial and never receive a positive settlement offer.

Both of the asymmetric information models discussed in Part V are capable of explaining a potentially large number of frivolous filings. However, these models point to a different sort of problem than commonly supposed. The most serious effect of frivolous litigation is not the cost of actually litigating frivolous suits, but instead the adverse impact on settlement of legitimate suits.

Part VI turns from prediction to policy prescription. I draw on the formal analysis to outline a general approach to regulating frivolous suits. In particular, I propose a way to determine whether suits are frivolous based on a failure to investigate. Moreover, I argue against uniform enforcement of a prohibition on frivolous suits and in favor of a more targeted approach that varies with the litigation context. Finally, I examine three enforcement alternatives and conclude that the more popular devices may not be as promising as generally believed and that a relatively neglected approach, judicial screening, deserves more attention than it has received.

\section{The VALUe OF MODELS}

\section{A. Modeling in General}

We rely on models all the time. By abstracting from the seemingly chaotic details of real life, models make it possible to perceive patterns otherwise hidden from view. ${ }^{18}$ Even when one does something as routine as changing lanes on a highway, one implicitly relies on an abstract model of human behavior to anticipate the reactions of other drivers. This model assumes, for instance, that other drivers care about avoiding accidents, and that they can and will observe one's behavior and respond rationally to it. ${ }^{19}$ As in this driver exam-

${ }^{18}$ On the value of modeling, see DAVD M. KREPS, GAME THEORY AND ECONOMIC MODELLING 5-7, 87-89 (1990) and ERIC RASMUSEN, GAMES AND INFORMATION: AN INTRODUCTION TO GAME THEORY $2-4$ ( $2 \mathrm{~d}$ ed. 1994).

19 The model also assumes that road conditions will remain relatively smooth and that the weather will not change abruptly. Of course, one can alter these assumptions if one observes something unusual, such as a weaving car or a bumpy road. Even so, the model does not always match reality; when the deviation is too large, a serious ac- 
ple, most models are not rigorously specified or technically precise like the formal models I discuss in this Article. Still, informal models are just like formal ones in the respect that makes modeling most valuable: they abstract from reality to render complex problems in a more tractable form.

Procedural analysis involves predicting the actions of parties in highly complex litigation settings. Not surprisingly then, proceduralists use models all the time, whether they are aware of it or not. Sometimes the use is explicit, as with the models discussed in this Article. More often, however, it is implicit, as it is for our hypothetical driver. For example, the seemingly straightforward prediction that increasing the number of judges will reduce case backlog relies on a simple model of the litigation process that assumes-incorrectly, as it turns out-that the number of possible lawsuits is fixed. ${ }^{20}$ Similarly, the assumption that relaxed summary judgment burdens will screen out weak cases without adversely affecting strong ones ${ }^{21}$ is based on a model of the litigation process that unrealistically abstracts from settlement. $^{22}$ And again, the relatively common assumption that a oneway offer-of-settlement rule like Rule 68 of the Federal Rules of Civil Procedure will encourage settlements by penalizing plaintiffs for rejecting reasonable offers ${ }^{23}$ implicitly relies on a model that ignores the interactional nature of settlement bargaining. ${ }^{24}$

Still, some people object to formal models on the ground that they abstract too much from context or make unrealistic assumptions about human rationality. ${ }^{25}$ These are important concerns, ${ }^{26}$ and a

cident can result.

${ }_{20}$ See George L. Priest, Private Litigants and the Court Congestion Problem, 69 B.U. L. REV. 527, 533-35 (1989) (noting that speedier disposition of cases will attract more suits into the system).

${ }^{21}$ See Celotex Corp. v. Catrett, 477 U.S. 317, 327 (1986) (stressing the value of summary judgment in weeding out meritless claims).

${ }_{22}$ See Samuel Issacharoff \& George Loewenstein, Second Thoughts About Summary Judgment, 100 YALE L.J. 73, 7475 (1990) (noting how a light summary judgment burden can adversely affect settlement by giving the moving party a chance to impose costs asymmetrically).

${ }_{23}$ See, e.g., Marek v. Chesny, 473 U.S. 1, 10-11 (1985) (arguing that Rule 68 encourages settlement without affecting incentives to bring meritorious suits).

${ }_{24}$ See Geoffrey P. Miller, An Economic Analysis of Rule 68, 15 J. LEGAL STUD. 93, 94 (1986) (showing that settlement frequency is not likely to increase much, but settlement amount is likely to drop).

${ }_{25}$ Formal models of the litigation process assume that individuals are rational in the special sense, associated with the theory of "rational choice," that they are able to maximize expected payoffs in the face of uncertain options, or more technically, that they maximize expected utility. See DAVID M. KREPS, A COURSE IN MICROECONOMIC 
good modeler tries to take account of them. ${ }^{27}$ But it is also important not to exaggerate the problems. For one thing, modeling assumptions may fit the competitive environment of litigation rather well, given that lawyers are trained to make strategic choices in the face of uncertainty. ${ }^{28}$ Moreover, when the fit is poor, the formal predictions can sometimes be adjusted to reflect the deviation. ${ }^{29}$ Furthermore, despite its limitations, this type of analysis is still the most rigorous and powerful method we have to predict behavior, ${ }^{30}$ and prediction is crucial to any policy analysis that counts consequences. Those who would reject formal modeling have the burden to identify a workable alternative that better fits what we know about the litigation environment. Thus far, no one has done so.

\section{B. Modeling Frivolous Litigation}

Modeling is particularly important for studying frivolous litigation because of the many obstacles to reliable empirical work in the field. ${ }^{31}$

THEORY 71-81 (1990) (describing the von Neumanin-Morgenstern theory of expected utility). See generally HOWARD RAIFFA, DECISION ANALYSIS: INTRODUCTORY LECTURES ON CHOICES UNDER UNCERTAINTY (1968) (providing a nontechnical account of the rational choice model).

${ }^{26}$ See, e.g., KREPS, supra note 25, at 112-20 (describing theoretical and empirical reasons to be cautious about rational choice analysis); Thomas S. Ulen, Rational Choice and the Economic Analysis of Larw, 19 L. \& SOC. INQUIRY 487, 490-515 (1994) (discussing anomalies in the theory of rational choice).

${ }_{27}$ See, e.g., Avery Katz, The Strategic Structure of Offer and Acceptance: Game Theory and the Law of Contract Formation, 89 MICH. L. REV. 215, 247-49 (1990) (also discussing special limitations of game-theoretic methods).

${ }^{28}$ Lawyers sometimes even use formal analysis explicitly. See Diane Goldner, Borrowing a Tool from Business School, AM. LAW., July-Aug. 1986, at 12-13.

${ }^{20}$ See, e.g., George Loewenstein et al., Self-Serving Assessments of Faimess and Pretrial Bargaining, 22 J. LEGAL STUD. 135, 140-53 (1993) (demonstrating that the economic analysis of settlement can be enhanced by considering the psychological factors influencing parties' behaviors).

${ }^{30}$ See Ulen, supra note 26 , at 521.

31 Most of the empirical work to date relies on surveys, which are especially sensitive to problems of respondent bias and framing. See JOHN SHAPARD ET AL., FEDERAL JUdicial CTR., REPORT OF A SURVEY CONCERNING RULE 11, FEDERAL RULes OF CIVIL PROCEDURE 3 tbls.1, 2 (1995) (survey of reactions to 1993 Rule 11 and its effect on groundless litigation); WillgiNG, supra note 12, at 3, 11 (survey of bench and bar reporting that 1983 Rule 11 reduced frivolous suits); Judges' Opinions on Procedural Issues: A Survey of State and Federal Trial Judges Who Spend at Least Half Their Time on General Civil Cases, 69 B.U. L. REv. 731, 735-36 tbls.1.1, 1.2 (1989) (Harris survey reporting that 21\% of federal judges and $14 \%$ of state judges believe frivolous litigation is a "major cause" of delays); Elizabeth C. Wiggins et al., Judicial Assessments of Rule 11: Its Effectiveness and Its Impact on Litigation in Federal Court, FJC DIRECTIONS, Nov. 1991, at 28, $28-29$ (survey of federal judges reporting that most "do not find groundless litigation to be a prob- 
One obstacle is the lack of a clear and generally accepted definition of a "frivolous suit." Another is the tricky problem of how to determine whether any given suit is frivolous. ${ }^{32}$ This problem is particularly acute because the most obvious source of information-judicial determinations of frivolousness-is not likely to represent the case population as a whole, and especially not cases that end in settlement. ${ }^{33}$ Finally, researchers cannot easily obtain settlement data because parties often keep settlements confidential, ${ }^{34}$ making it very difficult to test for what the models in this Article predict is one of the most serious effects of frivolous litigation: the adverse impact on settlement of legitimate suits. ${ }^{35}$

I am not suggesting that empirical work has nothing to offer. ${ }^{36}$ My point is that empiricism must be combined with formal analysis to obtain a clear enough picture of frivolous litigation to guide responsible regulation. Formal models can suggest testable hypotheses, and when these hypotheses are confirmed by empirical data, greater reli-

lem in counseled cases"); cf. Marshall et al., supra note 12, at 953 (survey of practicing lawyers reporting significant use of Rule 11).

${ }^{32}$ For example, perhaps the most thorough empirical study of medical malpractice litigation to date refused to draw any conclusions about frivolous litigation in part because of difficulties in determining which suits were frivolous. See HARVARD Medical Practice Study, Patients, Doctors, and LaWyers: Medical INJURY MALPRACTICE LITIGATION, AND PATIENT COMPENSATION IN NEW YORK 7-27 to 7-35 (1990) (also noting small sample size).

${ }^{33}$ Published opinions imposing sanctions are not representative of the population of frivolous suits, and computerized databases are liable to be incomplete. See STEPHEN B. BURBANK, AMERICAN JUDICATURE SOC'Y, RULE 11 IN TRANSITION: THE REPORT OF THE THIRD CIRCUIT TASK FORCE ON FEDERAL RULE OF CIVIL PROCEDURE 11, at xiii (1989) (noting limitations of data); Wiggins et al., supra note 31, at 7 (noting sharp differences in the rate of publication of Rule 11 opinions). Moreover, selection effects make it unlikely that adjudicated cases reliably represent the population of suits that settle. See, e.g., Keith N. Hylton, Compliance with the Law and the Trial Selection Process: A Theoretical Framework (1995) (unpublished manuscript, presented at the "Conference on the Economics of Litigation," Dec. 1995, sponsored by the John M. Olin Center for Law, Economics and Business, Harvard Law School, on file with the University of Pennsylvania Law Review) (discussing the importance of selection effects).

${ }^{34}$ The fact of settlement is often public information, but the amount usually is not. Even if the researcher promises anonymity by reporting data only in the aggregate, parties still have incentives not to cooperate, since all firms suffer if an industry obtains a reputation for easy settlement.

${ }_{35}^{35}$ See infra Part V.

${ }^{36}$ For a good discussion of the importance of empirical work in litigation, see generally Deborah R. Hensler, Researching Civil Justice: Problems and Pitfalls, L. \& CONTEMP. PROBS., Summer 1988, at 55. Controlled laboratory simulations might be helpful, but I am not aware of any such efforts. See, e.g., Elizabeth Hoffman \& Matthew L. Spitzer, Experimental Lazu and Economics: An Introduction, 85 COLUM. L. REV. 991 (1985) (reviewing the use of experimental methodology in law and economics). 
ance on the model and all of its predictions is justified. ${ }^{37}$

\section{DEFINING "FRIVOLOUS SUITS"}

Most commentators use the term "frivolous suit" without defining it, as if the meaning were obvious to all. But the concept is quite slippery. In the following discussion, I use examples to test several possible definitions of frivolousness in an effort to develop an attractive and relatively uncontroversial core notion for the rest of this Article.

One possible definition equates frivolousness with negative expected value suits; that is, suits in which the expected trial award is too small to cover plaintiff's litigation costs. I use the idea of "expected value" throughout this Article, so it is important to define it here. The expected value of an uncertain future outcome, such as the outcome of a trial, is defined as the value of that outcome if it happens, multiplied by the probability that it will happen. Thus, ignoring litigation costs for the moment, the expected value to the plaintiff of winning at trial is the value of the likely trial award if she wins, multiplied by the probability of winning. ${ }^{38}$ Similarly, the expected value to the plaintiff of losing at trial is the value of a loss (zero here), multiplied by the probability of losing. ${ }^{39}$ The expected value of trial in general, before subtracting for litigation costs, is the sum of the expected values of the two possible trial outcomes. ${ }^{40}$ Thus, when litigation costs exceed the expected value of trial-in other words, when the lawsuit has negative expected value ${ }^{41}$-a rational plaintiff will never actually try the case, and so will file only if she believes there is a good chance of obtaining a settlement. ${ }^{42}$

\$7 See generally ELINOR OSTROM ET AL., RULES, GAMES, AND COMMON-POOL RESOURCES (1994) (reviewing empirical research testing game-theoretic work on common-pool problems). For more on combining modeling and empirical research, see infra Part VI.A.1.

${ }_{38}$ For example, if the likely trial award is $\$ 50,000$ and the probability of winning is $80 \%$, then the expected value of winning (ignoring litigation costs) is: $80 \% \times \$ 50,000$ $=\$ 40,000$.

${ }^{39}$ Thus, if the probability of losing is $20 \%$, the expected value of a loss is: $20 \% \times \$ 0=\$ 0$.

${ }^{40}$ Carrying forward the example in footnotes 38 and 39 , the expected value of trial (ignoring litigation costs) is: $\$ 40,000+\$ 0=\$ 40,000$.

${ }^{41}$ To complete the example in the previous three footnotes, assume the plaintiff's litigation costs are $\$ 45,000$. Then the net expected value of trial is $\$ 40,000-\$ 45,000=$ $-\$ 5000$, and the lawsuit has negative expected value.

${ }^{42}$ Technically, expected value works only for risk-neutral plaintiffs, while most people are probably risk-averse. See RICHARD A. POSNER, ECONOMIC ANALYSIS OF LAW 
Frivolousness, however, is not the same thing as negative expected value. To see this, consider a products liability case in which plaintiff expects a trial award of $\$ 500,000$ if she wins and estimates her probability of winning at $60 \%$. Suppose that litigation costs are very high-estimated at $\$ 350,000$-because of the need to address complex scientific issues. Even though the suit has negative expected value due to the high litigation costs, ${ }^{43}$ the merits are too substantial to warrant the label frivolous. ${ }^{44}$

This example suggests a second possible definition: A lawsuit is frivolous whenever the probability of success is very small. This is an improvement, but it is still unsatisfactory. To see why, consider a variation on the products liability example. Suppose the case is extremely weak on the merits, so weak in fact that the plaintiff, who has access to all of the important evidence, believes that there is only a $5 \%$ chance that the defendant actually did the acts in question. Suppose further that juries in the particular jurisdiction are unusually prone to error and that their errors tend to be strongly biased in plaintiffs' favor. Confident in her trial strategy and expecting a favor-

12-13 (4th ed. 1992) (explaining risk preferences). Nevertheless, little of importance is lost by using the concept of expected value. Any lawsuit with negative expected value is also not worth trying for a risk-averse plaintiff, since an uncertain trial award is worth less to a risk-averse party than to a risk-neutral party. See id. at 557. Furthermore, in a contingency fee case, much of the litigation risk is borne by the lawyer, who, because of his ability to pool cases to minimize overall risk, is likely to have preferences more closely aligned with risk neutrality. See id. at 567; see also John C. Coffee, Jr., Understanding the Plaintiff's Attorney: The Implications of Economic Theory for Private Enforcement of Law Through Class and Derivative Actions, 86 COLUM. L. REV. 669, 705-06 (1986) (describing the effect of an attorney's ability to diversify risk, but also questioning the assumption of risk neutrality for small firms).

$(60 \% \times \$ 500,000)+(40 \% \times \$ 0)-\$ 350,000=-\$ 50,000$.

44 To condemn this suit as frivolous, one would have to believe that suits with positive expected value from a plaintiff's subjective point of view are the only suits that should consume the resources of a publicly subsidized court system. This is an extremely difficult position to defend on normative grounds. It is especially problematic for anyone who believes that litigation is about enforcing individual rights, but it is also problematic for someone who views litigation in efficiency terms. After all, a suit that has negative expected value to a plaintiff might have positive value to society once externalized public benefits are taken into account. For example, a civil rights or environmental case that seeks broad injunctive relief can help a widely-dispersed group or establish new law benefitting the public as a whole. See generally Steven Shavell, The Social Versus the Private Incentive to Bring Suit in a Costly Legal System, 11 J. LEGAL STUD. 333 (1982) (noting that lawsuits create external social benefits in terms of enhanced incentives to invest in precaution, while also creating external social costs such as litigation expenses for the defendant and the court system); Louis Kaplow, Private Versus Social Costs in Bringing Suit, 15 J. LEGAL STUD. 371 (1986) (elaborating on Shavell's arguments and answering his critics). 
able jury, the plaintiff estimates her probability of winning at $80 \%$, an estimate that makes the subjective expected value of her suit positive. I believe that most people would classify this suit as frivolous, notwithstanding the high probability of success, because of the extremely low likelihood that the defendant is in fact liable.

What matters, therefore, is not a plaintiff's subjective estimate of trial success, but instead a plaintiff's belief about whether a defendant is in fact liable. This suggests a third possible definition: A lawsuit is frivolous if a plaintiff files suit believing that there is only a very small likelihood that the defendant is liable. This definition comes close to capturing part of what we mean by frivolous, but it too needs further refinement.

Consider a civil rights test case in which the defendant is clearly not liable under established law, but the plaintiff advances a novel legal theory strongly at odds with settled precedent. One might call this suit "frivolous" if one believes that courts should be used to change the law only when precedent provides strong support for the change. On the other hand, one might treat the suit as legitimate if one believes that the growth of civil rights law depends on the willingness of lawyers to bring test cases that challenge established precedent. $^{45}$

As this example makes clear, we label a lawsuit "frivolous" not simply to say something about its merits, but to express a normative judgment that suit should not be brought. Because it ultimately rests on a view of the proper function of adjudication, this normative judgment can be controversial at times. This helps explain why it is so difficult to define frivolousness. People disagree about the conditions for legitimate suits, and at the deepest level, their disagreement implicates differing views about the value of adjudication.

Even so, I believe our third definition can be modified to capture a relatively uncontroversial sense of frivolousness: A lawsuit is frivolous if a plaintiff files suit knowing facts that decisively establish little or no chance of the defendant's objective liability on the basis of any of the legal theories plaintiff alleges. ${ }^{46}$ Here, the relevant knowledge concerns the defendant's objective liability, not the plaintiff's subjective

${ }^{45}$ See Eastway Constr. Corp. v. New York, 637 F. Supp. 558, $574-75$ (E.D.N.Y. 1986) (recognizing the importance of permitting novel legal arguments and not discouraging particular types of litigation when creating a standard for frivolousness).

${ }^{40}$ This is the classic case of a "bad faith" filing and is sanctionable in federal court under FED. R. CIV. P. 11 and 28 U.S.C. $\$ 1927$ (1994). 
evaluation of trial success. ${ }^{47}$ The italicized portion is meant to avoid the civil rights controversy by focusing attention on the substantive law that the plaintiff actually invokes. While there is bound to be disagreement over how "little" a chance is too little, there is also likely to be a threshold below which almost everyone would agree that a suit is frivolous.

This definition, however, is still not complete. It omits a second category that fits neatly into the idea of frivolousness. This second category, which is recognized by Rule 11 of the Federal Rules of Civil Procedure, ${ }^{48}$ includes lawsuits that the plaintiff files without conducting a reasonable prefiling investigation when such an investigation would have revealed facts establishing little or no chance that the defendant was actually liable on any of the legal theories alleged. In this second category, the plaintiff is faulted for an unreasonable failure to investigate, rather than, as in the first category, for a knowingly frivolous filing. There are bound to be disputes over what qualifies as "reasonable," of course, but disputes of this kind presume agreement on the general definition.

${ }^{47}$ This means that the facts must be such as to convince a person who knew everything about the case. For example, plaintiff might sue on a products liability theory, knowing for certain that he never used defendant's product. In circumstances where the facts are not so clear, however, frivolousness must be determined by reference to the quality of the plaintiff's prefiling investigation.

What if plaintiff, convinced that her suit lacks merit, files anyway in the hope of forcing a settlement, but later discovers facts that show a strong likelihood of liability? I believe most people would give plaintiff the benefit of her luck. Cf. Sussman v. Bank of Israel, 56 F.3d 450, 457-59 (2d Cir. 1995) (holding that no Rule 11 violation existed for filing with an improper purpose when suit was otherwise meritorious). The question of whether a plaintiff's suit is frivolous is similar to the question of whether a person is culpably negligent when her unreasonable conduct creates a risk but no tangible harm. The plaintiff's filing decision was unreasonable given her knowledge at the time of filing, but it ultimately caused no harm to the defendant, who was legitimately subject to suit all along. Cf. Christopher H. Schroeder, Corrective Justice and Liability for Increasing Risks, 37 UCLA L. REV. 439, $469-73$ (1990) (suggesting that corrective justice theories support tort liability whenever one's actions increase the risk of harm, regardless of whether harm actually materializes).

${ }^{48}$ See FED. R. CIV. P. 11(b)(3) (requiring an inquiry reasonable under the circumstances and a belief that factual allegations have evidentiary support or are likely to have evidentiary support).

${ }^{49}$ But there are certain to be easy cases at the extremes. See GeOrgene M. Valro, RUle 11 SANCTIONS: CASE LAW PERSPECTIVES AND PREVENTIVE MEASURES § 5.03[b] [2], at 5-21 (Supp. 1994) (noting that most courts sanction attorneys when they fail to inquire at all in to the factual and legal bases for a claim, defense or motion).

${ }^{50}$ See infra Parts V.B.3 (defining reasonableness), VI.A.2 (operationalizing the definition). 
Therefore, the definition of frivolous suit that I adopt for this Article includes two prongs: A suit is frivolous (1) when a plaintiff files knowing facts that establish complete (or virtually complete) absence of merit as an objective matter on the legal theories alleged, or (2) when a plaintiff files without conducting a reasonable investigation which, if conducted, would place the suit in prong (1). At the same time, however, it is important to remember that this definition states only sufficient, and not necessary, conditions for frivolousness. For instance, it does not include cases deemed "frivolous" because of unsound legal arguments rather than thin facts; ${ }^{51}$ nor does it include legally meritorious cases labeled "frivolous" because of a belief that plaintiff is too litigious." It does, however, permit us to address one of the most important complaints about the civil justice system-that there are too many factually groundless suits.

${ }^{31}$ See, e.g., Land v. Chicago Truck Drivers, 25 F.3d 509, 517-18 (7th Cir. 1994) (imposing Rule 11 sanctions on the ground that the party advancing a legal theory must reasonably investigate that theory's viability before forcing an opponent to defend against the claim); Chambers v. American Trans Air, Inc., 17 F.3d 998, 1006-07 (7th Cir. 1994) (imposing Rule 11 sanctions for the attorney's failure to research the appropriate law before asking for liquidated and exemplary damages under a statute which clearly did not allow the recovery of such damages). Nevertheless, the models discussed in this Article can be adapted to deal with cases involving unsound legal arguments, provided one first defines precisely when a claim is legally insufficient. See infra note 190 (discussing the definitional problem).

52 To illustrate, suppose that $A$ builds a fence that encroaches two inches over the property line of his neighbor $B$. $B$ has a meritorious suit in trespass against $A$ to obtain damages and perhaps even injunctive relief. See, e.g., Goulding v. Cook, 645 N.E.2d 54, 55-56 (Mass. App. Ct. 1995) (recognizing that a landowner is entitled at least to damages for an encroachment on his property); Tramonte v. Colarusso, 152 N.E. 90, 91 (Mass. App. Ct. 1926) (allowing the plaintiff to recover at least nominal damages, even though "the invasion of the plaintiff's rights were trifling"). Nevertheless, I believe that many people would consider it a sign of excessive litigiousness and a breach of neighborly norms for $B$ to sue, and some might even refer to $B$ 's suit as "frivolous" in view of the insignificance of the encroachment. Cf. ROBERT C. ELLICKSON, ORDER WITHOUT LAW: HOW NEIGHBORS SETTLE DISPUTES 52-64 (1991) (noting strong norms among Shasta County cattle herders against using courts to resolve disputes). This sentiment may partially account for the intense public reaction to cases reported to the press as "frivolous." One of the most notorious recent examples is the "McDonald's hot coffee case." See Liebeck v. McDonald's Restaurants, P.T.S., Inc., No. CV-93-02419, 1995 WL 360309 (D.N.M. Aug. 18, 1994) (reporting the jury's findings, including the compensatory damages award of $\$ 160,000$ and the punitive damages award of $\$ 2.7$ million); David G. Savage, GOP Targeting Huge Punitive Damage Awards, L.A. TIMES, Nov. 25, 1994, at Al (reporting on criticisms of suits like McDonald's). Disgust with the $M c$ Donald's litigation may have less to do with the legal merits and more to do with a pervasive feeling that it is simply unreasonable to sue over something as common as hot coffee. 


\section{Positive EXPECTEd VALUE MOdels}

All the formal models discussed in this Article are efforts to answer the central questions of frivolous litigation: Why would a rational plaintiff ever file a frivolous suit, and why would a defendant ever settle? One answer assumes that frivolous suits have positive expected value ("PEV"). I discuss these PEV models briefly in this Part before turning to a more plausible class of models, those that assume frivolous suits have negative expected value ("NEV"). My purpose here and elsewhere is to determine how serious a frivolous suit problem the various models predict and how strong a case each makes for regulation. $^{53}$

There are two ways for a frivolous suit to be PEV: (1) the plaintiff might expect substantial nonlegal benefits, or (2) the courts might make mistakes sufficiently often to create a high likelihood of trial success even in a meritless suit. ${ }^{54}$ However, neither explanation points clearly to a serious enough frivolous suit problem to warrant regulatory intervention.

The first explanation fits some, but not many, types of litigation. Occasionally plaintiffs file meritless suits just to impose litigation or reputation costs on opponents, hoping to secure some political or business advantage. ${ }^{55}$ Examples include suits to delay hostile takeovers, scuttle a competitor's business plans, frustrate a project or political cause, or embarrass a political opponent or personal enemy. ${ }^{56}$ Although there is evidence that strategic litigation of this sort is on

5s Therefore, I assume that the American rule on attorneys' fees is in place and that there is no regulation specially designed to deter frivolous suits (such as Rule 11 penalties).

${ }^{54}$ Of course, a meritless suit might also seem to have positive expected value when in fact it does not if the plaintiff is unaware of damaging evidence. This situation implicates the reasonableness of the plaintiff's prefiling investigation. See infra Part V.B.3.

${ }^{35}$ Suits brought by plaintiffs who like to litigate belong here as well. These suits should be rare, however, since few people are likely to have strong enough tastes for litigation to justify the high cost.

${ }^{36}$ See Ronald J. Gilson \& Robert H. Mnookin, Disputing Through Agents: Cooperation and Conflict Between Lauyers in Litigation, 94 CoLUM. L. REV. 509, 536-37 (1994) (discussing "strategic litigation," which seeks to secure advantages for the plaintiff rather than vindicate legal rights); Thomas A. Waldman, Comment, SLAPP Suits: Weaknesses in First Amendment Law and in the Courts' Response to Frivolous Litigation, 39 UCLA L. REV. 979, 985-86 (1992) (arguing that a desire to forestall political activism motivates business interests to initiate "strategic lawsuits against public participation," so called "SLAPPs"). 
the rise today, ${ }^{57}$ I am not aware of any hard data showing how common it is or how much of it is meritless. ${ }^{58}$ One thing, however, is clear: public concern about frivolous suits focuses not on these cases, but on those such as tort, securities and civil rights suits that are brought to obtain settlements rather than to harass.

The second explanation has a potentially broader reach. ${ }^{60}$ If trial error is high enough, the trial award large enough, and litigation costs small enough, expected trial recovery can exceed costs even for a completely meritless suit. ${ }^{61}$ The problem with this argument, however, is its premise: the probability of trial error is not likely to be substantial enough in frivolous suits. Indeed, even if error rates are relatively high in the ordinary case, they can still be very low in a frivolous suit-too low to make suit PEV. The reason is that a factfinder is much less likely to make a mistake when the evidence is strongly skewed in the defendant's favor, as in a meritless suit, than when the

${ }^{57}$ See Gilson \& Mnookin, supra note 56 , at 537.

${ }^{5}$ When such a suit has legal merit, my definition of frivolous does not apply despite the plaintiff's questionable motives. This is at least consistent with the view of those courts that refuse to impose Rule 11 sanctions when plaintiffs file otherwise legitimate claims for arguably improper purposes. See, e.g., Sussman v. Bank of Israel, 56 F.3d 450, 459 (2d Cir. 1995) ("A party should not be penalized for or deterred from seeking and obtaining warranted judicial relief merely because one of his multiple purposes in seeking that relief may have been improper."); Townsend v. Holman Consulting Corp., 929 F.2d 1358, 1362 (9th Cir. 1990) (recognizing that "it would be counterproductive to use Rule 11 to penalize the assertion of non-frivolous substantive claims, even when the motives for asserting those claims are not entirely pure"); $\mathrm{Na-}$ tional Ass'n of Gov't Employees v. National Fed'n of Fed. Employees, 844 F.2d 216, 222-23 (5th Cir. 1988) (refusing to impose sanctions despite evidence of malice and harassment because the complaint was nonetheless justified). But see Szabo Food Serv., Inc. v. Canteen Corp., 823 F.2d 1073, 1083 (7th Cir. 1987) (noting that Rule 11 targets a "colorable suit" brought "for the purpose of imposing expense on the defendant").

${ }^{39}$ See, e.g., OLSON, supra note 1 , at 25470 (giving examples of frivolous suits, most of which fall into this category). These cases are also the principal focus of recent congressional activity. See supra notes 7-11 and accompanying text.

For models that rely on this explanation of frivolous filings, see Lucian Arye Bebchuk \& Howard F. Chang, An Analysis of Fee Shifting Based on the Margin of Victory: On Frivolous Suits, Meritorious Suits, and the Role of Rule 11, 25 J. LEGAL STUD. 371, 376 (1996) (analyzing fee shifting as a way to deter frivolous plaintiffs who sue to exploit trial error) and A. Mitchell Polinsky \& Daniel Rubinfeld, Sanctioning Frivolous Suits: An Economic Analysis, 82 GEO. L.J. 397, 404-06 (1993) (analyzing the Rule 11 sanctioning process for frivolous suits with positive expected value because of trial error).

${ }^{61}$ Consider a suit in which plaintiff knows defendant is clearly not liable. If courts make mistakes, plaintiff $(\pi)$ will sue when:

(probability of error) $\times$ (trial award) $>$ ( $\pi$ 's litigation costs). 
evidence is more or less balanced between the parties. ${ }^{62}$

By our definition of frivolous, there must be evidence that strongly favors the defendant-so strongly that a rational plaintiff must be able to conclude with a high degree of confidence that the defendant is, in fact, not liable. For a plaintiff to assume at the same time that the risk of trial error is high, she must believe that any exonerating evidence will remain hidden or that an ordinary factfinder will mistake its significance. Neither belief is terribly plausible in a frivolous suit.

If a defendant is aware of exonerating evidence, as should often be the case after discovery, a factfinder is not likely to overlook its significance since the defendant will present it clearly. ${ }^{63}$ Of course, the defendant may never learn about the evidence. Defendant ignorance is most likely to occur in cases where the plaintiff has exclusive control over the evidence and is willing to lie despite the risk of criminal and civil penalties. ${ }^{64}$ However, if blatant lying were frequent-as it would have to be for PEV frivolous suits to pose a serious problemdefendants would have strong incentives to cross-examine vigorously and attack the plaintiff's credibility in every case. ${ }^{65}$ Although lying is bound to succeed sometimes, occasional success will not make such suits PEV. A rational party will focus on the average, not the excep-

62 In technical terms, the average error risk is actually the mean of a distribution of different risks across lawsuits of varying strength. As a result, the average risk can be quite high while the risk for frivolous suits located at the left tail of the distribution is very low.

${ }_{69}$ The plaintiff's lawyer will do everything in her power to cast doubt on the evidence, but she is not likely to succeed very often when the evidence is clearly exonerating. Indeed, I imagine that the chance of tricking a jury is substantial only in a relatively complex case. But the more complex the case, the higher the trial costs, and the higher the trial costs, the higher the error rate needed to justify suit for a fixed award. See supra note 61 .

${ }^{64}$ Consider a case where a plaintiff trips over her shoelaces and falls in a grocery aisle without any witnesses, and then falsely claims to have slipped on a puddle of water negligently left unattended. Here, the plaintiff's testimony is the only evidence on the critical issue of causation.

65 Lying might be more successful on issues as to which the defendant has the burdens of production and persuasion at trial. If plaintiffs have better access to the evidence, however, this fact would weigh in favor of assigning the burdens to them. See Ronald J. Allen, Presumptions, Inferences and Burden of Proof in Federal Civil Actions-An Anatomy of Unnecessary Ambiguity and a Proposal for Reform, 76 Nw. U. L. REV. 892, 896 (1982) (noting that the "burden of production in some classes of cases may be placed on one party if the means of proving the issue are normally within his or her knowledge"). 
tional, frivolous case. ${ }^{60}$

I do not mean that frivolous suits can never be PEV. My point is simply that the PEV segment of frivolous litigation is not likely to be serious enough by itself to warrant costly regulatory intervention-or so it seems in the absence of evidence to the contrary. But this is not all there is to frivolous litigation. Plaintiffs file frivolous suits when they are NEV, and it is in those cases that the most serious problems are likely to arise.

\section{NeGATIVE EXPECTED VALUE MODELS: COMPLETE INFORMATION}

There are several models of NEV litigation that explain frivolous filings in different ways. These models vary according to the assumptions they make about the parties' information. "Complete information" models assume that the plaintiff and defendant both know that the suit is frivolous. "Asymmetric information" models, by contrast, assume one party knows and the other does not. I briefly discuss complete information models in this section, and then, in Part V, I turn to the asymmetric information models.

In some types of litigation, information about liability is likely to be complete (or almost complete) from the outset. Consider a breach of contract dispute between a property owner and a contractor over whether a building has been constructed according to specifications. Suppose the contractor insists that he substantially performed, and the owner disagrees. Both parties should have all relevant information about liability; contract interpretation, after all, turns on objective manifestations of intent and each party knows the history of negotiations and the current condition of the building. As a result, both parties should know from the beginning whether the suit is frivolous.

In the simplest version of a complete information model, developed by Professors Rosenberg and Shavell, ${ }^{67}$ the plaintiff files suit because he expects an early settlement, and the defendant settles because settlement is cheaper than making a formal response. To illustrate, suppose it costs a plaintiff $\$ 500$ to file a frivolous suit that seeks $\$ 50,000$ in damages, and it costs defendant $\$ 1000$ to respond to

W A rational plaintiff also takes account of the risk of being penalized for perjury. This risk increases the cost of litigating, thereby reducing the expected value of suit, and can even turn a PEV suit into an NEV suit if detection is frequent enough.

${ }^{67}$ See Rosenberg \& Shavell, supra note 17, at 3. 
the complaint by formal answer or motion. Suppose further that the defendant must either respond or suffer a default judgment in the amount of $\$ 50,000$. Under these circumstances, defendant should be willing to pay up to $\$ 1000$ in settlement, even though she knows that the suit is frivolous and that the plaintiff will drop the suit if she makes a formal response. After all, settlement in an amount up to $\$ 1000$ is less than the cost of a formal response ( $\$ 1000)$ and certainly less than the cost of default $(\$ 50,000)$. Knowing this about the defendant, the frivolous plaintiff will file suit, since he expects a settlement $(\$ 1000)$ in excess of his filing cost $(\$ 500)$.

While this model might explain some frivolous filings, it cannot account for a serious frivolous suit problem. For one thing, unjustified wealth transfers ${ }^{68}$ in the form of settlement payments to frivolous plaintiffs should be individually quite small in magnitude, since settlements are capped at the relatively low cost of filing an answer (or a motion to dismiss). ${ }^{69}$ After all, the defendant knows all the material facts and need not worry about preparing for trial, so she should be able to get away with making simple denials. ${ }^{70}$ Furthermore, the

${ }^{68}$ By a "wealth transfer," I mean any payment from one party to another. Wealth transfers are "unjustified" when the payment is made to a party who is not entitled to it. For example, an "unjustified wealth transfer" occurs anytime a meritless suit settles for a positive amount. The phrase is meant to be general enough to encompass all possible normative reasons for objection, including adverse impacts on ex ante incentives and the moral injustice of the resulting redistribution.

${ }^{69}$ If a defendant files a motion to dismiss in federal court, she need not file an answer until the motion is denied. See FED. R. Crv. P. 12(a). Whether the defendant files a motion or an answer, the ball returns to the plaintiff, who must then invest an additional sum in order to advance the litigation. Moreover, defendants usually benefit from delay, see Coffee, supra note 42 , at 703 , and thus should be happy to wait until the plaintiff makes the next move. If the plaintiff does nothing, the court will dismiss the action for want of prosecution. See Link v. Wabash R.R., 370 U.S. 626, 629 (1962) ("The authority of a federal trial court to dismiss a plaintiff's action with prejudice because of his failure to prosecute cannot seriously be doubted.").

${ }^{70}$ In fact, if the cost of responding is less than the cost of filing, settlements would be too small to attract any frivolous suits. Furthermore, in actual litigation, both parties have bargaining power at the settlement stage, so any settlement should fall somewhere between zero (the amount the plaintiff accepts when the defendant has all the bargaining power) and the cost of an answer or motion (the amount the defendant accepts when the plaintiff has all the power, as the Rosenberg-Shavell model assumes). See Rosenberg \& Shavell, supra note 17, at 4-5. As a result, any settlement is likely to be less than the defendant's response cost, and therefore frivolous suits will be even less profitable than the Rosenberg-Shavell model supposes. For example, if the two parties in our hypothetical have equal bargaining power, the expected settlement should be roughly $\$ 500$ (one-half of the $\$ 1000$ response cost), not enough to make suit profitable when plaintiff must spend $\$ 500$ to file. 
model predicts very little in the way of wasted litigation costs, ${ }^{71}$ since all frivolous suits should settle shortly after filing.

More complex models might improve somewhat on these predictions, but they do not clearly point to a serious frivolous suit problem. ${ }^{73}$ Moreover, under complete information, there is a way for defendants to deal with frivolous suits on their own whenever they

7 Litigation costs are "wasted" whenever the presence of frivolous suits causes parties to invest more in litigation than they otherwise would.

${ }^{72}$ Rationally, all frivolous suits should settle before filing. See Rosenberg \& Shavell, supra note 17, at 11 n.5. Both parties know that the suit is frivolous and settlement inevitable, so both know that a prefiling settlement can save the cost of filing. Moreover, the usual reasons for settlement failure are not strongly implicated here, since transaction costs are low and there is no reason for plaintiff to worry about signaling weakness.

${ }^{79}$ For example, Professor Lucian Bebchuk has developed a model that shows how an NEV plaintiff might be able to force a defendant to litigate stage-by-stage all the way through trial. See Lucian Arye Bebchuk, A New Theory Concerning the Credibility and Success of Threats to Sue, 25 J. LEGAL STUD. 1 (1996). While this model has important implications for nonfrivolous NEV suits, its predictions for frivolous suits approximate those of the Rosenberg-Shavell model. For one thing, wasted litigation costs are not a problem in the Bebchuk model because settlements always take place shortly after filing. Moreover, settlement amounts should be small in frivolous suits, especially in view of the possibility of summary judgment and the availability of defensive measures that can increase plaintiff's costs. See, e.g., Emmons v. McLaughlin, 874 F.2d 351, 353 (6th Cir. 1989) (holding that appellant "failed to present 'specific facts' sufficient to defeat [a]ppellees' motion for summary judgment"); Contemporary Mission, Inc. v. United States Postal Serv., 648 F.2d 97, 107 (2d Cir. 1981) (holding that a party cannot defeat a motion for summary judgment by speculating "about what discovery might uncover"); 8 CHARLES A. WRIGHT ET AL., FEDERAL PRACTICE AND PROCEDURE $\$ \S 2036$ 37 (2d ed. 1994) (discussing bases for resisting discovery and grounds for obtaining protective orders). With a likelihood of summary judgment and a prospect of high costs at some litigation stage prior to trial, a frivolous plaintiff will have difficulty making a credible threat to litigate each stage (unless the stakes are unusually high), and without such a threat, settlement is likely to be close to the Rosenberg-Shavell amount. See Bebchuk, supra, at 14 (stressing the importance of credible threats).

There is a possible exception to this analysis. Bebchuk shows that if there is a stage where the plaintiff can force the defendant to invest without having to invest himself-what Bebchuk calls a "cost-free stage" - then the plaintiff can extract a settlement in an amount less than or equal to the difference between the defendant's and the plaintiff's anticipated litigation costs aggregated up to the cost-free stage. See Bebchuk, supra, at 20-22. For settlements to be substantial, however, costs must be highly asymmetric, and the parties must anticipate a cost-free stage late enough in the litigation for the cost differential to be large (yet early enough to precede a summary judgment). If litigation resembles a tennis match, with each return of the ball a separate stage, there would be many cost-free stages. But if litigation mostly involves concurrent moves from stage to stage, as I believe it does, then cost-free stages should be rare after the close of pleadings. To take one example, discovery requests are normally concurrent: parties propound requests on one another at roughly the same time. 
expect repeated filings. ${ }^{74}$ By litigating instead of settling the first few frivolous suits, a repeat-player defendant can build a reputation for fighting. ${ }^{75}$ Once established, this reputation will signal other frivolous plaintiffs not to expect a settlement, and so they will not sue. Because the gain from avoiding future settlements is likely to exceed the loss from litigating a few frivolous suits, ${ }^{76}$ defendants should find it optimal to employ a fighting strategy in many cases. 7

A fighting strategy can succeed, however, only when there is an effective mechanism for distributing reputational information. Distribution to corporate plaintiffs is not a problem because, as repeat players, they have the incentive and wherewithal to become informed.

${ }^{74}$ See Rosenberg \& Shavell, supra note 17 , at $10 \mathrm{n.3}$ (recognizing this possibility); Kent D. Syverud, The Duty to Settle, 76 VA. L..REV. 1113, 1160 \& n.118 (1990) (noting that insurance companies sometimes have incentives to litigate rather than settle in order to establish a tough reputation).

${ }^{75}$ It is possible that reputation effects might work on both sides of a lawsuit, but I believe this is rare. After all, a plaintiff's attorney would have to be willing to cultivate an unsavory and highly public reputation for litigating frivolous suits. By contrast, a defendant's reputation for fighting is perfectly consistent with high standards of professional conduct.

${ }^{76}$ This point is difficult to demonstrate rigorously without technical gametheoretic tools, see RASMUSEN, supra note 18, at 121-31, but it should be intuitively clear. In order for future settlements to have a significant impact on defendant's current incentives, the total amount of all future settlements must be very large. But in that case a defendant should be willing to invest in fighting a lot of frivolous suits if by doing so he could avoid paying large settlement amounts in future suits. A simple numerical example might help. Suppose a defendant expects to pay $\$ 50,000$ to settle a frivolous suit and $\$ 20,000$ to litigate. Suppose that the defendant also discounts the future by $90 \%$ (in other words, one dollar paid out one year hence costs defendant only 90 cents today). Assuming a continuous stream of frivolous filings, one each year, it can be shown that the present value of all future settlements is $\$ 500,000$. Even ignoring the discount factor, the defendant should be willing to litigate 24 frivolous suits at $\$ 20,000$ per suit to establish a reputation of fighting suits if it means that the rest of the frivolous filings would be deterred (since $24 \times \$ 20,000=\$ 480,000$, which is less than $\$ 500,000$ ).

${ }^{77}$ Without getting too deeply into the technicalities of game theory, it is worth mentioning that a fighting strategy might require an indefinite string of potential frivolous suits. This condition is not absolutely essential in true reputation models, but it is necessary to game-theoretic models that depend not on reputation but on a party's ability to punish deviations from a desired equilibrium. See RASMUSEN, supra note 18, at 121-31, 154-56. Fortunately, we need not worry about this technicality, since there is an indefinite string of frivolous suits whenever the defendant is a corporation with an indefinite life. As a matter of fact, the suits need not all be of the same type, since a reputation for fighting frivolous suits in general should reap benefits in any frivolous suit. Nor need the suits be infinitely numerous; it is enough that the parties to any frivolous suit assign a positive probability to the filing of yet another. See id. at $125-26$. 
Distribution to individual, one-shot plaintiffs, however, could be more difficult, except for the fact that the plaintiff's lawyer is well positioned to act as an informational conduit. Lawyers usually have access to reputational information through professional publications and personal contacts, and they have a strong incentive to screen frivolous suits, at least in contingency fee cases. ${ }^{78}$ Indeed, reputational information is part of a lawyer's general litigating capital, which is capable of generating returns in legitimate suits as well. As a result, lawyers have an incentive to become informed even when doing so is costly. ${ }^{79}$

Thus, complete information models do not provide a convincing explanation for why frivolous suits are problematic, at least not an explanation that justifies costly regulatory intervention. According to these models, frivolous suits all settle early, producing little in the way of wasted litigation costs, and settlements are likely to be quite small unless, for some reason, the stakes are unusually high. Moreover, defendants in some (perhaps many) cases should be able to deter frivolous suits on their own by using a fighting strategy. ${ }^{80}$

${ }^{78}$ After all, a lawyer at risk for fees is not likely to take a suit with little chance of success (unless for some reason the client tries to conceal the weakness and succeeds). See Kevin M. Clermont \& John D. Currivan, Improving on the Contingent Fee, 63 CORNELL L. REV. 529, 571-72 (1978) (arguing that a contingent fee does not necessarily encourage, and may well discourage, frivolous suits). It is significant, therefore, that many plaintiffs hire lawyers on contingency. See id. at $531 \mathrm{n} .2$ (noting that most personal injury cases are on contingency); David M. Trubek et al., The Costs of Ordinary Litigation, 31 UCLA L. REV. 72, 111-12 (1983) (reporting that 71\% of plaintiffs in a statistical sample hired lawyers on contingency). Attorneys paid on a fee-for-services basis might be more willing to file frivolous suits just to earn the fees, see Clermont \& Currivan, supra, at 572 , but this incentive should be reduced somewhat by the lawyer's interest in maintaining a good reputation.

${ }^{70}$ Agency problems might frustrate a fighting strategy if corporate officers and inhouse counsel prefer for some reason to settle frivolous suits even when fighting is better for the company as a whole. See generally POSNER, supra note 42, at 391-92 (discussing agency problems in the firm). I am not aware of any empirical data on this problem, but even if the problem were significant, there are sound reasons to rely on private solutions rather than public regulation. Companies have incentives to monitor their agents and are generally in a superior position to identify the source of the problem and correct it.

${ }^{80}$ These conclusions assume that litigation is very costly. When it is not, the risk of frivolous suits can be quite high. For example, if frivolous litigation by prisoners is a problem today, it is largely because prisoners incur little, if any, cost when they file pro se. See, e.g., Young v. Corbin, 889 F. Supp. 582, 586 (N.D.N.Y. 1995) (noting that the pro se plaintiff had filed 12 lawsuits, many of which were dismissed as frivolous). See generally Ana Puga, House GOP Aims to Halt 'Frivolous' Prison Litigation, BOSTON GLOBE, Feb. 5, 1995, at 2 (reporting on the congressional attempts to curb frivolous suits). A prisoner who knows that a suit is frivolous might sue just to play the odds, strike back at the state, pass the time, or even get a day outside the prison walls. Of course, state 


\section{NEGATIVE EXPECTED VALUE MODELS: ASYMMETRIC INFORMATION}

For a more plausible account, we must relax the assumption of complete information. ${ }^{81}$ One way to do this is to suppose that the plaintiff knows his suit is frivolous, but that the defendant does not. I call this the "informed-plaintiff model." A second way is to suppose that the defendant knows, but the plaintiff does not unless he investigates. I call this the "informed-defendant model." The following discussion describes each of these two asymmetric information models in turn, first illustrating the model's intuition with a simple narrative, and then briefly describing its formal structure and predictions. The discussion closes with a critical examination of the reliability of both models and an overall summary of their most important predictions.

\section{A. The Informed-Plaintiff Model}

The informed-plaintiff model fits a number of different litigation settings-for example, a negligence suit in which liability turns on contributory negligence and in which the defendant cannot observe the plaintiff's conduct, or a products liability case in which the plaintiff knows he did not use the defendant's product. ${ }^{82}$ These models have received a fair amount of attention in the law and economics literature. ${ }^{83}$ The following analysis is based on a model developed by Professor Avery Katz. ${ }^{84}$

defendants should often be able to get early summary judgment, or possibly even dismissal, when the plaintiff is proceeding in forma pauperis under 28 U.S.C. $\$ 1915$, especially with the qualified immunity defense, see Harlow v. Fitzgerald, 457 U.S. 800, $813-$ 19 (1982) (detailing the elements of a qualified immunity defense), and heightened pleading standards, see Blum, supra note 4 , at 59, 59-61 (discussing the use of a heightened pleading standard to "weed out frivolous claims"). But litigation costs might still be a serious problem in the aggregate, since a fighting strategy is useless against lowcost plaintiffs.

${ }_{81}$ Option theory might provide an alternative way to explain frivolous filings. See Bradford Cornell, The Incentive to Sue: An Option-Pricing Approach, $19 \mathrm{~J}$. LEGAL STUD. 173,187 (1990) (summarizing option theory). However, it is too early to assess the promise of option theory, especially as proponents have yet to consider the effects of strategic interaction. Id. at 174.

See, e.g., Jones v. International Riding Helmets, Ltd., 49 F.3d 692, 695 (11th Cir. 1995) (affirming the imposition of Rule 11 sanctions in a products liability case in which the plaintiff's attorney knew that the helmet plaintiff used was manufactured before the defendant company existed).

${ }^{83}$ See Lucian Arye Bebchuk, Suing Solely to Extract a Settlement Offer, 17 J. LEGAL STUD. 437 (1988); Katz, supra note 17.

${ }^{84}$ See Katz, supra note 17. 


\section{A Simple Narrative: John v. Mary}

To see intuitively what might happen when plaintiffs are informed, consider the following simple hypothetical. One day while shopping at a neighborhood grocery store owned by Mary, John tripped over his shoelaces, fracturing his elbow and sustaining some permanent injury. No one observed John's fall, and it occurred to him that he might claim that he slipped on-a nearby puddle of water and collect damages from Mary.

Suppose John is not willing to lie under oath, so trial is out of the question. Assume that both Mary and John consult attorneys who have considerable experience with personal injury cases, especially slip-and-fall suits, and that John's attorney is not averse to filing frivolous suits if a profit can be made. Both attorneys rely on their experience to estimate trial success, the likely jury verdict, and expected litigation costs for the average legitimate slip-and-fall case. Assume that the attorneys have similar experience and so make the same estimates, which are as follows: (1) legitimate plaintiffs prove lack of reasonable care, on average, $80 \%$ of the time at trial; (2) the average jury verdict awards $\$ 50,000$ for injuries like John's; and (3) the average case costs $\$ 1000$ to file and $\$ 10,000$ for each side to litigate through trial.

What will the parties do? For ease of exposition, I shall refer to the decisionmakers as "John" and "Mary" even though I mean to include their attorneys as well. John asks himself whether he should sue, knowing that his case is frivolous and has no chance of success at trial. Mary asks herself whether to offer a settlement and in what amount. However, unlike John, Mary does not know for sure whether the suit is frivolous. The parties reflect on their options as follows: ${ }^{85}$

John reflects: I certainly don't want to sue if Mary will just refuse to settle. After all, it will cost me $\$ 1000$ to file, and I get nothing unless Mary makes a settlement offer. But there is hope because Mary doesn't know whether my suit is frivolous. Of course, if she believes that the vast majority of suits are frivolous, then she might not be willing to settle at all. But if instead she believes that most suits are legitimate, then she might be willing to make a high offer in order to avoid

${ }^{85}$ I am deeply indebted to my colleague, Joe Brodley, for his invaluable assistance with this narrative as well as those in infra Part V.B.1. 
the risk of spending $\$ 10,000$ for trial.

Mary reflects: I have no idea whether John's suit is frivolous. If his suit has merit, I should certainly make an attractive settlement offer-on these facts, an offer in the amount of $\$ 30,000^{86}$-because settlement avoids my $\$ 10,000$ cost of going to trial. ${ }^{87}$ If John's suit is frivolous, however, I should refuse to settle. Of course, I could offer an amount somewhere between zero and $\$ 30,000$, but that would be pointless. Anything less than $\$ 30,000$ is not attractive to legitimate plaintiffs (who expect to do better than that at trial), so only frivolous plaintiffs would accept. But frivolous plaintiffs drop if I simply refuse to settle. So I should either offer $\$ 30,000$ or refuse to settle.

If I offer $\$ 30,000$ all the time, all potential frivolous plaintiffs will sue. I could refuse to settle and try to deter frivolous suits, but that is also costly. To succeed, I must refuse to settle most, if not all, cases, and that means paying $\$ 10,000$ for trial every time a suit turns out to be legitimate.

What to do? Well, I know from experience how likely it is that a fall, such as the one John alleges, is due to the fault of a grocery store owner, so I can estimate the relative proportion of potential frivolous and legitimate suits similar to John's. If the proportion of potential frivolous suits is fairly small, then it would be better for me to offer $\$ 30,000$ all the time and settle with everyone. To be sure, this strategy will attract all the frivolous plaintiffs, but there aren't that many, so I will end up buying off a frivolous plaintiff only once in a long while. But since there are lots of legitimate suits, offering a settlement that would be accepted by a legitimate plaintiff will save a great deal on trial costs. On balance, I gain much more by paying off a few frivolous plaintiffs and saving trial costs in

${ }^{86}$ In this hypothetical, John, a rational actor with a legitimate suit, calculates an expected value of $\$ 30,000$ from going to trial: $80 \%$ (chance of success) $\times \$ 50,000$ (award) $-\$ 10,000$ (cost) $=\$ 30,000$. See supra notes $38-42$ and accompanying text (defining expected value). Therefore, John will settle for $\$ 30,000$ (or more), but will reject any offer for less.

${ }^{87}$ In fact, Mary expects to lose an additional $\$ 20,000$ by going to trial instead of settling a legitimate suit-although this is not important to the narrative. If Mary goes to trial, she spends $\$ 10,000$ and faces an $80 \%$ chance of paying a $\$ 50,000$ award. Therefore, her expected loss is $\$ 10,000$ (cost) $+80 \%$ (chance of loss) $\times \$ 50,000$ (liability) $=\$ 50,000$. This is $\$ 20,000$ more than the $\$ 30,000$ settlement. 
many legitimate suits.

On the other hand, if the proportion of potential frivolous suits is large, it wouldn't be a good idea for me to settle with all plaintiffs. Doing so would attract too many frivolous suits. So I am better off in this situation by refusing to settle at least some of the time to deter frivolous filings. Of course, I could refuse to settle all the time, but that is costly when a suit turns out to be legitimate. ${ }^{88}$ Perhaps there is a happy medium here-I could refuse to settle some of the time to deter many of the frivolous plaintiffs, but not so much of the time that I end up paying a lot for trials.

$$
* * * *
$$

This narrative captures the essential intuition: ${ }^{89}$ Plaintiffs with frivolous suits try to take advantage of a defendant's ignorance by filing in the hope that the defendant will believe that the suit is legitimate and make the same offer she would make to a legitimate plaintiff. Defendants know this about frivolous plaintiffs and so are inclined to discourage frivolous filings by refusing to settle. The problem is that refusing to settle can be costly for the defendant if the suit turns out to be legitimate. In the end, what the parties actually do depends on their beliefs about the proportion of potential frivolous suits, since the costs and benefits of alternative strategies depend on those beliefs.

John has the same information as Mary and is a rational maximizer like Mary, so John can perfectly anticipate what Mary will do, and vice versa. Thus, John predicts that Mary always offers $\$ 30,000$ when the proportion of potential frivolous suits is relatively small. So John and all plaintiffs like John sue, just as Mary predicted they would.

In game theory, this result is known as an "equilibrium." The

${ }^{88}$ More precisely and somewhat more technically, if defendants like Mary never settle, then only legitimate plaintiffs will sue. In that case, defendants do better by switching to $\$ 30,000$ offers in all cases. If this occurs, however, all frivolous plaintiffs would sue, and defendants would do better switching again. In other words, refusing to settle all the time is not a stable strategy because it induces too strong a response from frivolous plaintiffs.

${ }^{89}$ The reader familiar with game theory will notice that the final paragraph of the narrative glosses over some of the complexity of mixed strategies in order to convey the intuition. See infra note 93 (defining mixed strategies). A mixed strategy is difficult to present intuitively in the context of a single game; it is much easier to understand as a statistical prediction of behavior over a large number of identical games. See infra note 94 (describing the statistical interpretation).

${ }^{90}$ RASMUSEN, supra note 18, at 14-28. Technically, this is called a "Perfect Bayesian 
idea of an equilibrium follows from the special complexity of strategic analysis. Strategic thinking involves a process of moving back and forth between the parties-asking first how one party $(A)$ might act, then checking how the other $(B)$ would respond, and then checking again that $A$ would still act in the specified way if he anticipated $B$ 's response. John in our narrative decides what strategy to employ by anticipating Mary's response, but Mary's response depends on what John decides to do. In an equilibrium, each party acts in precisely the way the other party anticipates, so neither has an incentive to deviate and both do the best they can by following their prescribed strategy.

For example, given a small enough proportion of potential frivolous suits," Mary does the best she can by always offering $\$ 30,000$ when she believes frivolous plaintiffs like John always file, and John does the best he can by filing when he believes that defendants like Mary always offer $\$ 30,000$. Thus, an equilibrium has a self-reinforcing quality. When the parties follow their equilibrium strategies, their beliefs are confirmed by their experience, so they have no reason to switch to a different strategy. If all parties in similar cases act as John and Mary do, then Mary will come to believe that frivolous plaintiffs like John always file since that is what they actually do-and so too for John's belief about defendants like Mary.

The simple narrative also reveals a second equilibrium, which holds when the proportion of potential frivolous suits is relatively large. ${ }^{92}$ In these cases, plaintiffs like John predict that defendants like Mary will refuse to settle much of the time-so frequently in fact that plaintiffs file only some of the time. ${ }^{y 3}$ As this description suggests, the best way to interpret this second equilibrium is to focus not on John and Mary, but on all potential frivolous plaintiffs like John and all defendants like Mary. Viewed in this way, the predictions furnish statistical information: they tell us how often frivolous plaintiffs in general sue

\footnotetext{
Equilibrium." Id. at 145-52.

${ }^{91}$ It can be shown using technical reasoning that this equilibrium holds whenever the proportion of potential frivolous suits is less than $40 \%$. See Appendix, IV.A.

92 It can be shown that this second equilibrium holds whenever the proportion of potential frivolous suits exceeds $40 \%$. See Appendix, IV.A.

9s In game theory, John and Mary are said to adopt "mixed strategies." See RASMUSEN, supra note 18, at 67-83. The name comes from the fact that the parties "mix" between their possible strategies. See id. at 68 . In our hypothetical, defendants like Mary mix by offering $\$ 30,000$ some of the time and nothing the rest of the time, and plaintiffs like John mix by suing some of the time and not suing the rest of the time.
} 
and how frequently frivolous and legitimate suits end in settlement. ${ }^{94}$

\section{The Formal Model and Its Predictions}

The abstract version of the informed-plaintiff model tracks our simple narrative. There are only two types of suit, frivolous and legitimate, and the plaintiff knows which type she has while the defendant does not. The model assumes that frivolous suits always lose at trial, and that legitimate suits all have the same chance of success on average. Moreover, the model also assumes that defendants and plaintiffs can estimate from experience the fraction of potential frivolous and legitimate suits; that is, the fraction of all persons who could file a frivolous suit and the fraction who could file a legitimate suit. ${ }^{95}$ In the simple hypothetical, for example, we assumed John and Mary (with their attorneys) had enough experience with slip-and-fall cases to be able to estimate the likelihood that a slip-and-fall accident such as the one John alleged was due to grocer negligence. ${ }^{96}$

${ }^{94}$ See id., at 70-71. For example, suppose that the proportion of potential frivolous suits is $\mathbf{5 0 \%}$. With a technical analysis, one can show that frivolous plaintiffs sue about $67 \%$ of the time and receive settlements $($ of $\$ 30,000)$ about $3 \%$ of the time, and that legitimate suits settle about $3 \%$ of the time and go to trial about $97 \%$ of the time. See Appendix, IV.A. The statistical interpretation avoids a source of awkwardness in applying mixed strategies to a single game; namely, that they seem to require players to flip coins or run random number generators. See John Harsanyi, Games with Randomly Disturbed Payoffs: A Nezw Rationale for Mixed Strategy Equilibrium Points, 2 INT'L J. GAME THEORY 1 (1973) (showing how mixed strategies can make sense in a single game when there is uncertainty about payoffs). Yet, it is important to understand that this interpretation does not require plaintiffs (or defendants) to cooperate or coordinate in any way. The idea is not that all frivolous plaintiffs get together and decide how often to file. Quite the contrary. Each plaintiff (and each defendant) acts separately to maximize his or her own private return. Because the environment is highly interactive, however, the optimal choice for any one person depends on what everyone else does. For example, if frivolous plaintiffs were ever to file with a frequency greater than the equilibrium rate of $67 \%$, some defendants would eventually observe the change and realize that they would do better by refusing to settle all the time. Gradually, the proportion of settlements would fall below the equilibrium rate of $3 \%$, and some frivolous plaintiffs, observing the decline, would realize that they do better by never filing. As a result, the filing rate would gradually fall, eventually returning to the equilibrium rate of $67 \%$. The same dynamic works in the opposite direction: deviations by defendants from the equilibrium rate of offers will be dampened by plaintiffs' responses and forced back toward the equilibrium in the long run. See Katz, supra note 17, at 12 (noting that his equilibria are stable under just such a dynamic adjustment process). Therefore, like the invisible hand of the market, the interactive nature of the litigation environment makes the equilibrium a good statistical approximation of average behavior over the long run.

${ }_{95}$ This is a standard modeling assumption. See RASMUSEN, supra note 18 , at $48-56$.

${ }^{96}$ It is worth mentioning a somewhat technical point here. Theoretically at least, 
The sequence of events in the formal model, which tracks those in the John and Mary hypothetical, can be diagrammed on the following timeline:

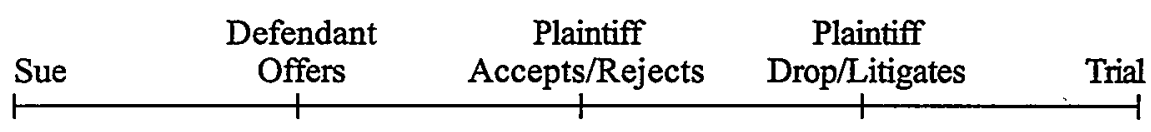

First, a potential plaintiff with a frivolous suit decides whether or not to file. (The model assumes that legitimate plaintiffs always file.) If a potential plaintiff files, the defendant next must decide whether to offer a settlement and in what amount. If the defendant offers a settlement, the plaintiff decides whether to accept. If no offer is made or if the plaintiff rejects, then the plaintiff decides whether to drop or go to trial.

For simplicity, the model assumes that there is only one chance to settle and that the parties cannot bargain over the settlement amount. Thus, the offer is take-it-or-leave-it, and the case goes to trial if the plaintiff rejects and does not drop. The model also assumes, again for the sake of simplicity, that the defendant's task of choosing and communicating an offer and the plaintiff's task of responding are costless.

The model predicts two different equilibria, paralleling those in the John and Mary hypothetical. In the first, the proportion of potential frivolous suits is low enough that defendants find it worthwhile to offer all plaintiffs the amount that a legitimate plaintiff would accept (i.e., the expected trial award from a legitimate suit net of litigation costs), and accordingly, all frivolous plaintiffs file. ${ }^{97}$ Because all suits settle in this equilibrium, little in the way of litigation costs is wasted. However, there is a potentially serious problem of unjustified wealth transfers. The problem is much more serious than in the complete

anyone could file a frivolous suit, even someone totally unconnected to the transaction or event. Obviously, this cannot define the universe of potential plaintiffs, for then the fraction of potential frivolous plaintiffs would always be close to $100 \%$. The key to limiting the universe is to remember that party expectations control choice of strategy. Clearly, no reasonable person would ever expect all the world to sue. Indeed, parties are likely to limit the universe of potential plaintiffs to those persons having some reasonable connection to the transaction or event and otherwise fitting the general profile of the case.

${ }^{97}$ See Katz, supra note 17, at 10-12 (referring to this equilibrium as the "restricted entry equilibrium"). For a mathematically precise specification, see Appendix, II.A. 
information model because settlements are much larger. ${ }^{98}$ Moreover, the problem gets worse as the expected trial award in a legitimate suit $^{\text {yg }}$ increases. This is because an unjustified wealth transfer occurs each time a frivolous plaintiff obtains the settlement intended for a legitimate suit, and the amount of such a settlement increases with the expected trial award.

In the second equilibrium, the proportion of potential frivolous suits is large enough that defendants are not willing to settle with all plaintiffs. Instead, defendants, like Mary, make the offer that a legitimate plaintiff would accept some, but not all, of the time, and frivolous plaintiffs, like John, sue some, but not all, of the time. ${ }^{100}$ The most serious problem in this second equilibrium turns out to be wasted litigation costs, not unjustified wealth transfers. This is because defendants refuse to settle most of the time, so few frivolous suits are rewarded while many legitimate suits go to trial. ${ }^{101}$ Moreover, it is also possible to show, with some technical analysis, that the problem gets worse as the expected trial award in a legitimate suit increases. ${ }^{102}$

These predictions suggest that some form of regulation might be desirable to deter frivolous filings in those litigation settings where a plaintiff is likely to have critical private information. Moreover, although each equilibrium is associated with a different kind of problem-unjustified wealth transfers in one, and wasted litigation costs in

${ }^{98}$ See supra notes 68-73 and accompanying text (arguing that complete information settlements will be small on average).

${ }^{99}$ The "expected trial award" is the probability of success times the anticipated award without deduction for costs. For example, in the John and Mary hypothetical, the expected trial award is $\$ 40,000$ (i.e., $80 \% \times \$ 50,000$ ).

${ }^{100}$ See Katz, supra note 17 , at 12-13 (referring to this equilibrium as the "competitive equilibrium"). For a mathematically precise specification, see Appendix, II.B.

${ }^{101}$ See supra note 94 (noting that when the proportion of potential frivolous suits is $50 \%$, only $3 \%$ of frivolous plaintiffs receive settlements in equilibrium, but $97 \%$ of legitimate suits go to trial). For a mathematically precise specification, see Appendix, II.B.

${ }^{102}$ To illustrate, consider what happens in the John and Mary hypothetical, assuming the fraction of potential frivolous suits is $50 \%$, when the expected trial award in a legitimate suit is raised from $\$ 40,000(80 \% \times \$ 50,000)$ to $\$ 80,000(80 \% \times \$ 100,000)$. When the trial award is $\$ 40,000$, it can be shown that parties spend on average a total of $\$ 10,000$ per suit. See Katz, supra note 17 , at 16 . When the trial award is $\$ 80,000$, however, parties are likely to spend more on the litigation because the stakes are higher. See POSNER, supra note 42, at 525, 532-33. If expenditures increase proportionately with the expected award, for example, total litigation costs will equal $\$ 20,000$ per suit when the expected award is $\$ 80,000$. 
the other-both problems become more severe as the average expected trial award in legitimate suits increases. This suggests that litigation settings with high trial awards should have a priority claim on scarce regulatory resources.

\section{B. The Informed-Defendant Model}

Sometimes it is the defendant rather than the plaintiff who knows that a suit is meritless. In this situation, if the plaintiff does not investigate before filing, when he should, and files a meritless suit, the resulting litigation is frivolous within the second prong of my definition. Examples include medical malpractice suits in which the patient has no direct knowledge of what the doctor did; antitrust and civil rights suits that depend on the defendant's intent, motivation or similar state of mind; and securities fraud class actions that are only thinly investigated in the rush to be the first to file. ${ }^{103}$

The informed-defendant model analyzes this situation. This model is a bit more complicated than the informed-plaintiff model because of the investigation option. However, the intuition is readily conveyed by a hypothetical and simple narrative based on a medical malpractice case.

\section{A Simple Narrative: Paul v. Susan}

Susan, a surgeon at a major hospital, operated on Paul. A year after the operation, Paul suffers from occasional, mild dizzy spells. Hospital doctors cannot identify the cause but insist that it has nothing to do with the operation. Paul, who was anesthetized, has no idea what actually happened during the operation.

Paul consults an attorney who specializes in medical malpractice cases. Susan, of course, has access to hospital legal counsel, who are also very experienced with malpractice cases. As in the John and Mary hypothetical, assume here that the average meritorious case fac-

${ }^{103}$ See, e.g., Lorentzen v. Anderson Pest Control, 64 F.3d 327, 329 (7th Cir. 1995) (products liability); Oliveri v. Thompson, 803 F.2d 1265, 1279 (2d Cir. 1986) (civil rights); Blancato v. Saint Mary Hosp., No. CIV.A.91-4114, 1993 WL 273687 (E.D. Pa. July 21, 1993) (medical malpractice); Janet Cooper Alexander, Do the Merits Matter? A Study of Settlements in Securities Class Actions, 43 STAN. L. REv. 497, 513-14, 577 (1991) (securities class actions). Indeed, Congress recently enacted the Private Securities Litigation Reform Act mainly in response to perceptions of a serious frivolous suit problem in the securities field. See Private Securities Litigation Reform Act of 1995, Pub. L. No. 104-67, 109 Stat. 737 (codified in scattered sections of 15 U.S.C.). 
tually similar to Paul's has an $80 \%$ chance of success at trial and receives a jury award of $\$ 50,000$; that a meritless case never wins at trial, and that all lawsuits, meritorious and meritless alike, cost $\$ 1000$ to file and $\$ 10,000$ per side to litigate through trial. Assume further that the $\$ 10,000$ cost is split evenly between discovery and trial, so that $\$ 5,000$ is spent at each stage. Assume also that discovery always reveals whether suit is meritless and that Paul and Susan estimate that $50 \%$ of all potential suits ${ }^{104}$ are meritless (that is, $50 \%$ of the time symptoms like Paul's are not caused by surgical error).

Imagine how Paul and Susan (together with their attorneys) might reflect on their options. I use the labels "meritorious" and "meritless" rather than "legitimate" and "frivolous," throughout the following discussion in order not to beg the question of when prefiling investigation is reasonable. ${ }^{105}$

Paul reflects: I would certainly like to know whether my case is meritorious. I know from experience that many of these kinds of cases have real merit. I could investigate, but that would cost me a lot of time and money. That's a pity because Susan already knows the facts. Of course, she insists there is no problem, but I can't trust her because she would say the same thing even if there was. How can I bring her knowledge to light in a reliable way? Suppose I don't investigate, but simply file suit. If I have a good case, it will be in Susan's interest to make me a good settlement offer. Thus, Susan's offer could tell me whether I have a good case. So I think I'll just wait to see what Susan does.

Susan reflects (assuming Paul's suit is meritless): I know Paul's suit is meritless, and I want him to know as well. I have tried to tell him numerous times, but of course he doesn't believe me. I could just refuse to settle, ${ }^{106}$ and maybe that would persuade him and he would drop. To do that in a credible way,

${ }^{104}$ See supra notes 95-96 and accompanying text (discussing this assumption).

${ }^{105}$ A meritless suit is always frivolous in the informed-plaintiff model, since plaintiff knows the suit lacks merit. But here a meritless suit is frivolous only if plaintiff should have investigated, and we do not yet know when that duty should attach.

${ }^{106}$ Of course, Susan could make a very low "nuisance suit" offer in a meritless case, as the complete information models predict. See supra notes 67-69 and accompanying text. I simplify, however, and assume defendants refuse to settle meritless cases. Allowing for a nuisance settlement does not change the basic results as long as the settlement is not too large. 
however, I have to refuse to settle all meritless cases. But then I will be informing meritorious plaintiffs that their suits have value, and they will hold out for large settlements. Indeed, if I know that plaintiffs don't investigate and rely on a refusal to settle as a sign that a suit lacks merit, I should always refuse to settle, because that would trick meritorious plaintiffs into believing that their suit lacks merit too. But the problem is that plaintiffs would eventually learn what I was doing and investigate, thereby undermining my strategy and forcing me to spend for discovery and trial.

$* * * *$

This simple narrative captures the intuition: Plaintiffs like Paul want to identify the kind of suit they have, and they want to do so in the least expensive way. They have three alternatives: they can find out themselves by investigating before filing; they can file and hope that defendants like Mary tell them by making different offers in meritorious and meritless suits; or they can file and go through discovery. Each option is costly, and plaintiffs compare the costs when determining their optimal strategy.

Defendants have opposing incentives. Defendants want plaintiffs to know the truth when their suit is meritless, but not when their suit is meritorious. Thus, defendants in meritorious cases try to deceive plaintiffs by pooling, that is, by making the same offer they would make if the suit was meritless. The problem is that plaintiffs eventually learn that they are being tricked, and they respond by relying less on the defendant's offer and more on investigation or discovery (whichever is cheaper). Defendants, in turn, worry more about paying for discovery and trial in meritorious cases and so they pool less frequently and make an attractive offer more frequently.

In game theory, this is known as a "signaling game" because a defendant's settlement offer can "signal" a plaintiff as to the kind of suit he has. ${ }^{107}$ The signaling game between Paul and Susan has three possible equilibria, depending on the cost of investigation. I illustrate these different equilibria with the following three simple scenarios. In each, Paul asks himself whether to investigate before filing, whether to file, and how to respond to a settlement offer if one is made-all without knowing whether his case has merit. Susan asks herself whether to offer a settlement and in what amount. Unlike

${ }^{107}$ See generally RASMUSEN, supra note 18, at 249-68 (discussing signaling games). 
Paul, however, she knows whether the suit is meritorious, but cannot observe directly whether Paul has investigated.

\section{a. Scenario \#1-Investigation Costs $\$ 100$}

Suppose that Paul can rule out the possibility that his suit is meritless by consulting a specialist at a cost of $\$ 100$, and suppose that Paul and Susan both know this fact. Assume, for instance, that the specialist can tell by examining Paul and his health history whether negligent surgery could possibly have caused his dizziness. The parties reflect as follows:

Paul reflects: By spending relatively little (\$100), I can determine whether my case has merit and save the $\$ 1000$ filing cost if it turns out to be meritless. What are my other options? I could just file and hope that I learn from Susan's offer. But then I would waste the $\$ 1000$ filing cost if the suit turns out to be meritless. I know that $50 \%$ of all cases like mine are meritless, so I can expect to incur this $\$ 1000$ cost $50 \%$ of the time, for a real (expected) cost to me of $\$ 500$. Because investigation costs only $\$ 100$, I clearly do better by investigating. My other option, discovery, is even more expensive, so I better consult the specialist.

Susan reflects: It's very cheap for Paul to investigate. In fact, it's so cheap that I know he will do so even if he expects me to signal him perfectly by offering $\$ 30,000$ in a meritorious case and refusing to settle a meritless case. Therefore, I can assume Paul is informed. It follows that I should refuse to settle when the suit is meritless, because then an informed Paul will drop his suit. And I should offer $\$ 30,000$ when suit is meritorious, because then Paul will accept, saving me the $\$ 10,000$ cost of discovery and trial.

$* * * *$

The Equilibrium Prediction. Therefore, we have the following general prediction: If $50 \%$ of all potential suits are meritless and the cost of investigating is $\$ 100$, then all plaintiffs will investigate before filing and file only meritorious suits, and all meritorious suits will settle for $\$ 30,000$. $^{108}$ This result is not at all surprising given the very low cost of

${ }^{108}$ In other words, defendants like Susan do the best they can by offering $\$ 30,000$ in meritorious cases and nothing in meritless cases when they expect plaintiffs like Paul 
investigation. Indeed, we know that the equilibrium holds whenever the investigation cost is less than $\$ 500$ on these facts (and more generally, whenever the investigation cost is less than the expected cost of filing a meritless suit).

\section{b. Scenario \#2-Investigation Costs $\$ 5000$}

Suppose now that it is very difficult for Paul to tell whether negligent surgery could possibly have caused his dizziness, so difficult in fact that Paul would have to spend $\$ 5000$ to investigate. At the extreme, perhaps Paul may have to bribe hospital personnel to divulge confidential records or tell him what they saw or heard during the surgery. On this new assumption, the parties reflect as follows:

Paul reflects: Investigation is pretty expensive here, though it would save me the cost of filing and possibly also litigating a meritless suit through discovery. What if I just file instead? The worst that could happen is that I would litigate all the way through discovery and then find out that the suit is meritless. This wastes $\$ 6000$ in filing and discovery costs, but only if my suit turns out to be meritless, which happens $50 \%$ of the time. As a result, the real (expected) cost to me is $\$ 3000$ (50\% of $\$ 6000$ ), and this is less than the $\$ 5000$ I must spend to investigate. So I am better off filing without investigating and seeing what Susan does.

Susan reflects (assuming Paul's case is meritorious): Investigation is so costly that Paul will never investigate, so I'm dealing with an uninformed plaintiff. I could therefore refuse to settle. That would be a good idea if it tricks Paul into believing the suit is meritless and he drops. But it would be a bad idea if Paul decides to find out what kind of suit he has by litigating. In that case, I would have to pay $\$ 10,000$ for discovery and trial, an extra expense that I could have avoided by settling. Of course, I could just offer $\$ 30,000$. But that would be a pity if the uninformed Paul would have dropped if I had refused to settle. My third alternative is to offer an amount between zero and $\$ 30,000$. But that makes no sense at all. Paul

always to investigate, and plaintiffs like Paul do the best they can by always investigating when they expect defendants like Susan to make the two different moves (offer $\$ 30,000$ or refuse to settle) depending on the merits of the case. 
expects defendants in meritless suits to refuse to settle, ${ }^{109}$ so he will read an offer greater than zero as a sign that the suit is meritorious and will reject it if the offer is less than $\$ 30,000$ (what he expects to get by going to trial).

What to do? If I refuse to settle, I risk paying for trial unnecessarily, but if I offer $\$ 30,000$, I miss an opportunity to trick an uninformed plaintiff. I wish I knew what Paul would do. If I could be sure that he would drop, I should refuse to settle. But if Paul expects defendants like me to do this in all meritorious cases, he will litigate further to find out what kind of suit he has, and I will end up paying for trial. ${ }^{110}$ If I could be sure Paul would litigate, then I should offer $\$ 30,000$. But if Paul expects this, then he would interpret a refusal to settle as a sign that the suit is meritless and drop. But then I would do better by refusing to settle.

Therefore, neither of my two alternatives is clearly optimal given my uncertainty about Paul. Perhaps there is a happy medium. I could offer $\$ 30,000$ sometimes and refuse to settle the rest of the time. This strategy would save a little on discovery and trial and also allow me to benefit somewhat from plaintiff's ignorance. And if plaintiffs like Paul expect this strategy, they are likely to respond to a refusal to settle by litigating sometimes and dropping sometimes. By dropping sometimes, plaintiffs like Paul save some of the wasted costs of conducting discovery in a meritless suit, and by litigating sometimes, they reap some of the benefits when the suit turns out to be meritorious.

$$
* * * *
$$

The Equilibrium Prediction. Therefore, we have the following general prediction: If $50 \%$ of all potential suits are meritless and the cost of investigating is $\$ 5000$, plaintiffs will never investigate; all plaintiffs will sue; defendants will offer $\$ 30,000$ some of the time and refuse to settle the rest of the time when the suit is meritorious, and will always refuse to settle when suit is meritless; and plaintiffs will drop their suits some of the time and litigate the rest of the time whenever de-

${ }^{109}$ For the intuition supporting this belief, see infra note 122.

${ }^{110}$ On our factual assumptions, plaintiffs like Paul always litigate when defendants pool completely. The reason is that plaintiffs learn nothing from the offer and calculate a positive expected value of litigating (having already sunk the filing cost) equal to $0.5 \times \$ 30,000-0.5 \times \$ 5000=\$ 12,500$. 
fendant refuses to settle. ${ }^{\mathrm{II}}$ As a result, all meritless suits will be filed, some meritless suits will proceed through discovery, some meritorious suits will settle for $\$ 30,000$, some meritorious suits will be dropped, and the remainder of the meritorious suits will go to trial. ${ }^{112}$ This equilibrium holds whenever investigation costs exceed $\$ 3000$ (or more generally, exceed the expected cost of filing and discovery in a meritless suit). ${ }^{\text {"s }}$

\section{c. Scenario \#3-Investigation Costs $\$ 2000$}

Finally, consider what happens when the cost of an investigation is moderate. Assume, for instance, that Paul can find out whether his suit is meritless by spending $\$ 2000$.

Paul reflects: I could investigate. But if I do that and Susan expects it, then I know that she will offer $\$ 30,000$ if my suit is meritorious and refuse to settle if my suit is meritless [like Scenario \#1]. Therefore, I will learn from her offer what kind of suit I have. In that case, I do better by filing without investigating. With $50 \%$ potential meritless suits, filing costs me

${ }^{11}$ This equilibrium involves mixed strategies and the reader versed in game theory will notice that the final paragraph of the narrative glosses over the technical difficulties in order to convey the intuition. For more on mixed strategies, see supra notes 93-94 and accompanying text (explaining how mixed strategies make sense in the absence of cooperation or coordination).

${ }^{112}$ In fact, as we saw was true for the informed-plaintiff model, see supra note 94 , it is possible to predict the equilibrium rates at which defendants offer $\$ 30,000$ and plaintiffs drop. Again the technical details are beyond the scope of this Article, but it can be shown that defendants like Susan will make the $\$ 30,000$ offer about $83 \%$ of the time in meritorious suits, and plaintiffs like Paul will drop $40 \%$ of the time in response to a refusal to settle. See Appendix, III.D.2 (giving the general formulae), IV.B.2 (calculating the results for this hypothetical). As a result, $83 \%$ of all meritorious suits settle for $\$ 30,000$, about $7 \%$ are dropped, and about $10 \%$ are litigated through trial. Moreover, all meritless suits are filed and $60 \%$ go through discovery.

${ }^{113}$ In game theory, this is known as a "partial pooling equilibrium" because defendants in meritorious suits sometimes "pool" with defendants in meritless suits by also refusing to settle. (In contrast, the equilibrium in Scenario \#1 is known as a "separating equilibrium.") See RASMUSEN, supra note 18, at 148-50. This partial pooling equilibrium has a self-reinforcing quality. For example, using the rates in note 112 , supra, if defendants were to pool more often than $17 \%$ of the time, some plaintiffs would eventually observe the deviation and realize that it was better to litigate than drop. Gradually, the litigation rate would rise above $60 \%$, and some defendants, observing this increase, would realize that it was better to separate than pool. As a result, the pooling rate would gradually fall, eventually returning to the equilibrium rate of $17 \%$. 
$\$ 500$ in expected loss [from Scenario \#1], and that's a lot less than $\$ 2000$ for an investigation. So, if Susan expects me to investigate, I do better by not investigating. But she knows what I know and can figure that out, so I won't be able to trick her.

I could just file without investigating. But if Susan expects this, she will try to trick me by refusing to settle a meritorious case, and I will have to litigate sometimes in order to learn my suit type at the discovery stage [just as I did in Scenario \#2]. But it never makes sense to use discovery to learn suit type; investigating is less expensive. I know [from Scenario \#2] that discovery costs $\$ 3000$ in expected loss, more than the $\$ 2000$ for investigating. So, if Susan expects me to file without investigating, I do better investigating. Again, however, Susan can figure that out, so I cannot trick her this way either.

What to do? Neither of my two alternatives is optimal. Simply put, always investigating wastes an opportunity to learn from Susan's offer, and always just filing (without investigating) wastes money on discovery if the suit turns out to be meritless. Perhaps there is a happy medium for plaintiffs like $\mathrm{me}^{114}$ - we could investigate only sometimes and drop in response to a refusal to settle whenever we don't investigate. This way, we learn something from the settlement offer and avoid the cost of using discovery to find out the suit type.

Susan reflects (assuming Paul's suit is meritorious): I believe plaintiffs like Paul investigate sometimes, but I don't know whether Paul has investigated in this case. I could just refuse to settle. That might trick Paul if he has not investigated, but it will cost me $\$ 10,000$ for trial if he has investigated. I could offer $\$ 30,000$ instead. That would be a good idea if Paul has investigated, since I save trial costs that way. But it would be a pity to offer $\$ 30,000$ if Paul has not investigated. Therefore, neither alternative is optimal. I could offer something between zero and $\$ 30,000$, but that makes no sense. Paul knows

${ }^{114}$ If Paul is a one-shot litigant, it may seem odd to express his decision in terms of a random choice between two options. This reflects the problem with describing mixed strategies in a single game. See supra note 89 . The switch from the singular "I" to the plural "we" is meant to express the result in terms of a statistical prediction over the entire class of plaintiffs, which is exactly the way Susan would look at it. See supra notes 93-94 and accompanying text (discussing mixed strategies and showing how to interpret them in a noncooperative game). 
that defendants like me always refuse to settle meritless suits, so he will interpret an offer greater than zero as a sign that his suit is meritorious and reject my offer.

What to do? Perhaps there is a happy medium here. I could offer $\$ 30,000$ sometimes in meritorious cases and refuse to settle the rest of the time. When I refuse to settle, plaintiffs like Paul will drop if they have not investigated, so I get some of the benefit of pooling. Moreover, when I offer $\$ 30,000$, I get some of the benefit of avoiding a trial against an informed plaintiff.

$$
* * * *
$$

The Equilibrium Prediction. Therefore, we have the following general prediction: If $50 \%$ of all potential suits are meritless and investigation costs $\$ 2000$, there is a partial pooling equilibrium in which plaintiffs investigate sometimes but not always; plaintiffs sue when they investigate and the suit turns out to be meritorious, and also sue when they do not investigate; defendants in meritorious suits offer $\$ 30,000$ some of the time and refuse to settle the rest of the time; defendants in meritless suits always refuse to settle; and uninformed plaintiffs always drop when defendants refuse to settle. This equilibrium holds on these facts whenever the investigation cost is between $\$ 500$ and $\$ 3000$ (or more generally, when the investigation cost is between the expected cost of filing a meritless suit and the expected cost of filing and conducting discovery in a meritless suit). In this equilibrium, some but not all meritless suits are filed. Moreover, some meritorious suits settle for $\$ 30,000$, some are dropped, and the rest go to trial (but no meritless suits ever go through discovery). ${ }^{115}$

${ }^{115}$ It is possible to predict the equilibrium rates of investigation and $\$ 30,000$ offers. The analysis is technically complex, but it shows that plaintiffs like Paul investigate $60 \%$ of the time and defendants like Susan make the $\$ 30,000$ offer in $90 \%$ of the meritorious cases. See Appendix, III.D.3. (giving the general formulae), IV.B.3 (calculating the results for this hypothetical). Changing the facts produces even more serious results. For example, suppose that the average meritorious case has a $60 \%$ chance of success; juries award $\$ 200,000$ on average; filing costs $\$ 1000$; discovery costs $\$ 19,000$ for plaintiffs and $\$ 20,000$ for defendants; trial costs $\$ 20,000$ for both parties, and $60 \%$ of all potential suits are meritless. On these new facts, and assuming that a prefiling investigation costs $\$ 11,000$, it can be shown that plaintiffs will investigate about $50 \%$ of the time and defendants will make an attractive settlement offer (here in the amount of $\$ 81,000$ ) about $68 \%$ of the time. See Appendix, IV.B.4.a. The result is that roughly $50 \%$ of all meritless suits are filed; $16 \%$ of all meritorious suits go to trial, and $16 \%$ of all meritorious suits are dropped (because plaintiffs are uninformed). Thus, roughly one-third of all meritorious suits end in a problematic outcome-either they go to trial or they are dropped-entirely due to the presence of 


\section{The Formal Model and Its.Predictions}

The formal model tracks the structure of the Paul and Susan hypothetical. Many of its assumptions are the same as those in the informed-plaintiff model. For example, there are only two types of suit (meritorious and meritless); meritless suits always lose at trial; all meritorious suits have the same probability of success; plaintiffs and defendants know the background proportion of potential meritless suits; settlement negotiations are costless; there is only one opportunity to settle; and all settlement offers are made on a take-it-or-leave-it basis. " However, the information structure is reversed: the defendant always knows whether the suit is meritless, but the plaintiff only knows if he investigates.

The sequence of events can be diagrammed on the following timeline:

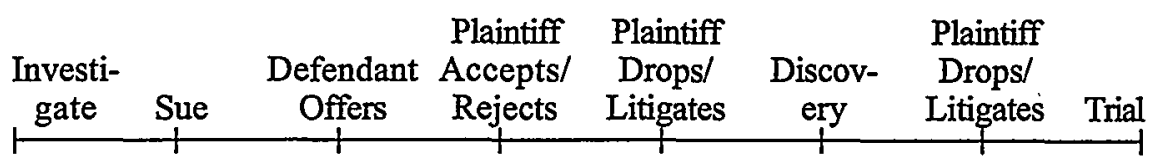

In the first stage, plaintiffs like Paul decide whether or not to investigate. Investigation is costly, but it also reveals information about whether a suit is meritless. For simplicity, the model assumes that investigation perfectly reveals the type of case and saves nothing on costs later in the litigation.

Whether or not he investigates, plaintiff must next decide whether to sue. I assume that plaintiffs sue when they know their suit is meritorious (otherwise no suits would ever be filed), and also when they are uncertain because they have not investigated. ${ }^{117}$ If the plaintiff sues, the defendant next decides whether to make a settlement offer and for what amount, knowing the kind of case but not knowing

meritless suits.

"In addition, the plaintiff and the defendant are both assumed to be riskneutral, as in the informed-plaintiff model. They both have access to the same information and thus agree on the probability of success, likely trial award, cost of filing, and cost of discovery and trial for each side.

${ }^{117}$ This assumption in effect eliminates the less interesting equilibria set out in Appendix, III.A. Simply stated, if plaintiffs never sue when they are uninformed, then either they investigate and file only meritorious suits, or if an investigation costs too much, they never sue. 
whether plaintiff knows. ${ }^{118}$ If the defendant makes an offer, the plaintiff must decide whether to accept or reject. If the plaintiff accepts, the parties settle for that amount. If the plaintiff rejects or if the defendant refuses to settle, the plaintiff has a chance to drop the suit. If the plaintiff does not drop, he takes the case through discovery. During discovery, the plaintiff learns whether his suit is meritless if he does not know already, and he gets another chance to drop after discovery. If plaintiff does not drop at this point, the case is tried.

Although this model is somewhat more complicated than the informed-plaintiff model, the Paul and Susan narrative illustrates the basic intuition and strategic dynamics. The fundamental result is that rational plaintiffs sometimes file meritless suits without investigating, even when they know that investigation at moderate cost perfectly reveals the suit type and that meritless suits have absolutely no chance of winning at trial or eliciting a positive settlement offer from the defendant. Equally important, the model shows why plaintiffs do not investigate: they rely on obtaining information from defendant's settlement offer.

More precisely, the informed-defendant model has three possible equilibria that depend on the cost of investigation when all other parameters are fixed:

The Investigation Equilibrium. In the equilibrium that corresponds to Scenario \#1, investigation costs are very low-less than the expected cost of filing a meritless suit. Under these circumstances, plaintiffs always investigate and file only meritorious suits. Anticipating this, defendants always make an offer that meritorious plaintiffs accept. As a result, no meritless suits are filed and all meritorious suits settle, so there are no wasted litigation costs, except the cost of investigating, and no unjustified wealth transfers. I shall refer to this equilibrium as the "investigation equilibrium."

The Filing Equilibrium. In the equilibrium corresponding to Scenario \#2, investigation costs are very high-greater than the expected total filing and discovery cost in a meritless suit. ${ }^{119}$ This might hold,

${ }^{118}$ Thus, the model in fact has two-sided asymmetric information: the plaintiff does not know whether his suit is meritless without doing an investigation, and the defendant does not know whether plaintiff has investigated.

${ }_{19}$ Technically, it is also necessary to assume that defendant's discovery cost is not too large, or equivalently, that the fraction of potential meritless suits is not too high. When defendant's discovery cost exceeds a certain threshold $(\$ 12,500$ in the Paul and Susan hypothetical, assuming $50 \%$ potential meritless suits), defendants in meritless suits will make an offer that an uninformed plaintiff accepts. It turns out that defen- 
for example, in a civil rights suit that turns on conspiracy or state of mind evidence that is difficult to obtain without formal discovery, ${ }^{120}$ or in a medical malpractice case like the Paul and Susan hypothetical. ${ }^{121}$ Under these circumstances, it is less expensive for plaintiffs to learn suit type by discovery, so they always sue without investigating. Anticipating this, defendants never settle meritless suits, ${ }^{122}$ and exploit plaintiffs' ignorance by sometimes refusing to settle meritorious suits. Expecting this, plaintiffs sometimes litigate through discovery to learn suit type, and defendants, concerned about the risk of paying for discovery and trial in meritorious suits, sometimes make an offer attractive to a meritorious plaintiff. ${ }^{123}$

I call this the "filing equilibrium" because plaintiffs always file and never investigate. The presence of potential meritless suits has two

dants always offer this amount whether the suit is meritorious or meritless; plaintiffs always accept, and all suits settle. The main problem is the large number of unjustified wealth transfers. For the precise characterization of this pure pooling equilibrium, see Appendix, III.C.2.

1:0 See, e.g., Oliveri v. Thompson, 803 F.2d 1265, 1279 (2d Cir. 1986) (stating that it would be unlikely for the plaintiff in a civil rights case to possess enough information to support his allegations before formal discovery); Weiss v. Coca-Cola Bottling Co., No. 91 C 1475, 1994 WL 327381, at 10 (N.D. Ill. July 6, 1994) (mem.) (stating that discovery was warranted to determine the merits of the discriminatory discharge claim). See generally Carl Tobias, Rule 11 and Civil Rights Litigation, 37 BUFF. L. REV. 485, 493-95, 497-98 (1989) (discussing the conflict between Rule 11's prefiling investigation requirement and the fact that information may not be available to a civil rights plaintiff until discovery).

${ }_{121}$ See, e.g., Henry S. Farber \& Michelle J. White, Medical Malpractice: An Empirical Examination of the Litigation Process, 22 RAND J. ECON. 199, 215-16 (1991) (discussing the asymmetric information problem in medical malpractice suits).

${ }^{122}$ This can be seen intuitively in the following way. Raising the settlement offer has two opposite effects. On the one hand, it makes settlement more costly. On the other, it increases the rate of acceptance, reducing the number of times defendant has to pay for discovery. Pooling dilutes the second effect, however, so the first dominates. Therefore, the defendant does best by refusing to settle when the suit is meritless. For a rigorous proof, see Robert G. Bone, An Investigation Model of Frivolous Suits (1995) (unpublished manuscript on file with the University of Pennsylvania Law Revietv).

There is another, somewhat more technical, way to understand these strategic dynamics. Recall that plaintiffs have three options to learn suit type: investigating, signaling and relying on discovery. Here investigating is more expensive than discovery, so plaintiffs eliminate that option at the outset. Plaintiffs could just rely on discovery all the time, in which case they would always litigate in response to a refusal to settle. This option, however, ignores the fact that signaling also provides information. As plaintiffs increase their use of discovery to learn suit type, defendants pool less often, so the pool includes fewer defendants in meritorious suits. Thus, a refusal to settle sends a stronger signal of meritless litigation, and the stronger the signal, the less worthwhile it is for plaintiffs to rely on discovery. Therefore, a plaintiff's optimal strategy strikes a balance between discovery and signaling to minimize learning costs. 
adverse effects in this equilibrium. First, it creates wealth transfers from plaintiffs to defendants by occasionally inducing plaintiffs with meritorious suits to drop in response to a refusal to settle. Second, it induces trials in meritorious suits that otherwise would have settled, and it also forces filing, and sometimes even discovery, in meritless suits. $^{124}$

These effects create two types of efficiency loss compared to the situation when all plaintiffs investigate: they distort incentives and increase total litigation costs. These results are difficult to demonstrate intuitively, so I shall summarize them here and provide examples in the footnotes. (The technical reader can confirm the analysis by using the formulae in the Appendix. ${ }^{125}$ )

The adverse impact on incentives follows from the fact that defendants end up paying more on balance because of higher litigation costs, even though they save somewhat because of favorable wealth transfers. ${ }^{26}$ The prospect of a larger loss can cause defendants to invest more in precaution than they would if all plaintiffs investigated, and the additional investment can produce a suboptimal allocation of resources relative to an investigation equilibrium.

Furthermore, total litigation costs are greater in the filing equilibrium, provided that the cost of an investigation is not too high. This is because the wasted cost of unnecessary trials as well as filing and discovery in meritless suits exceeds the additional investigation cost incurred when plaintiffs always investigate. ${ }^{127}$

${ }^{124}$ This prediction is confirmed by one empirical study of medical malpractice litigation that found that a substantial number of plaintiffs went through discovery, learned their suit was meritless, and then dropped. See Farber \& White, supra note 121, at 215-16 (hypothesizing that hospitals have information about liability that can be credibly disclosed to plaintiff only through discovery). Furthermore, the lack of investigation in the filing equilibrium might also help explain the results of another empirical study that found an abnormally high frequency of refusals to settle by defendants in medical malpractice suits. See Samuel R. Gross \& Kent D. Syverud, Getting to No: A Study of Settlement Negotiations and the Selection of Cases for Trial, 90 MicH. L. REv. 319, 360-64 (1991) (explaining the phenomenon by the nature of insurance arrangements).

${ }^{125}$ See Appendix, III.D.2.

${ }^{126}$ For example, in the Paul and Susan hypothetical, Susan's expected loss is $\$ 16,500$ per suit when no plaintiffs investigate and only $\$ 15,000$ when all plaintiffs investigate. See Appendix, III.D.1.b, D.2.b. (giving formulae for expected loss).

${ }^{127}$ For example, consider the Paul and Susan hypothetical, but assume that investigation costs $\$ 4000$. On these facts, total litigation costs are $\$ 5000$ per suit, on average, when no plaintiffs investigate and $\$ 4500$ per suit when all plaintiffs investigate. To illustrate the necessity of the proviso that the cost of an investigation not be too high, consider the results when investigation cost is $\$ 5000$, as in the original hypo- 
Efficiency is not the only concern. Fairness is also relevant because wealth transfers can violate fairness norms. In the filing equilibrium, when plaintiffs with meritorious suits drop, the resulting transfer of wealth systematically deprives plaintiffs of their entitlements. Plaintiffs can avoid the loss by investigating, but the cost is too high to make an investigation rational. ${ }^{128}$

The Mixed Equilibrium. In the equilibrium corresponding to Scenario \#3, investigation costs are moderate-greater than the expected cost of filing a meritless suit, but less than the expected cost of taking the suit through discovery. Many of the informed-defendant cases fit this profile. In these cases, plaintiffs investigate sometimes, but not always. Anticipating this, defendants always refuse to settle meritless suits. Worried about paying trial costs when plaintiffs investigate, however, defendants frequently make attractive settlement offers in meritorious suits. At the same time, since plaintiffs do not always investigate, defendants know that they can gain from pooling, so they refuse to settle meritorious suits some of the time. Furthermore, because investigation costs are moderate, plaintiffs always do better investigating when the alternative is to take a meritless case through discovery, so they always drop when they have not investigated and the defendant refuses to settle. ${ }^{124}$ I shall refer to this situation as "the mixed equilibrium" because plaintiffs mix between investigating and simply filing.

The presence of meritless suits produces the same two effects as in the filing equilibrium, although they are less serious because plaintiffs sometimes investigate. Meritless suits create unjustified wealth transfers from plaintiffs to defendants whenever meritorious suits are dropped and waste litigation costs by generating unnecessary trials in meritorious suits and filing costs in meritless suits.

thetical. Then total litigation costs are lower when no plaintiff investigates: they drop from $\$ 5500$ per suit to $\$ 5000$ per suit.

${ }_{128}$ A complete fairness analysis must engage a tricky moral question: Is it ever morally acceptable to impose a loss that would otherwise be unfair just because the victim failed to take advantage of a feasible, though irrational, way of avoiding it?

${ }_{129}$ An argument similar to the one in note 123, supra, can be developed. Here, investigation is less expensive than discovery, so plaintiffs eliminate the discovery option at the outset. Moreover, as plaintiffs investigate more frequently, defendants pool less frequently, and the signaling value of a refusal to settle increases accordingly, making investigation less worthwhile. The optimal strategy strikes a balance between investigation and signaling to minimize plaintiffs' learning costs. 


\section{Defining a "Reasonable" Prefiling Investigation}

The analysis so far has bracketed the normative question of when a failure to investigate is unreasonable and thus the filing of a lawsuit "frivolous." We now have the necessary background to address this question.

It is useful to divide the analysis into two stages, separating issues of duty from issues of enforcement. In the first stage, discussed in this section, I derive the ideal conditions for imposing a duty to investigate on the first-best assumption that compliance is perfect and costless. In the second stage, discussed in Part VI, I relax the strong compliance assumption to determine the best way to enforce the duty given the costs of alternative enforcement schemes.

First, note that requiring investigation all the time is equivalent to forcing the parties into an investigation equilibrium. Assuming perfect compliance, defendants will expect plaintiffs to be informed, and therefore will make attractive offers in all meritorious suits and refuse to settle meritless suits should any be filed. Anticipating this, plaintiffs will file only meritorious suits, and all such suits will settle.

Second, observe that the equilibrium analysis of the previous section narrows the inquiry in a useful way. It focuses attention on the filing and mixed equilibria, since plaintiffs already investigate in the investigation equilibrium. More importantly, it frames a sensible approach to the inquiry. To evaluate the desirability of an investigation requirement, we should examine the way the critical variables-total litigation costs, plaintiff's expected recovery and defendant's expected loss-change when the investigation requirement forces the parties to shift from a filing or mixed equilibrium to an investigation equilibrium.

Equations derived from the formal equilibrium analysis permit calculation of total litigation costs, expected recovery and expected loss in each of the three different equilibria, all within the confines of the formal model. ${ }^{130}$ The results make a strong case for requiring investigation in the mixed equilibrium. The shift from a mixed equilibrium to an investigation equilibrium leaves private litigation costs (including investigation costs) unchanged, but reduces public costs by reducing the number of discovery and trial events. Moreover, the shift does not change plaintiff's expected recovery or defendant's ex-

${ }^{130}$ See Appendix, III.D (giving mathematical formulae for litigation costs [LC], the plaintiff's expected recovery [EV], and the defendant's expected loss [EL]). 
pected loss, when both are measured prior to any injury or suit.

These results clearly support an investigation requirement on efficiency grounds, since investigation reduces total costs without changing expectations and thus incentives. But what about rights-based or fairness theories? Such theories are distinctive for their individualized focus and therefore are not likely to be concerned with probabilistic expectations measured from a distant ex ante point of view. ${ }^{131}$ Yet, even on this more individualized metric, an investigation duty is justified in the mixed equilibrium. According to the model, defendants never pay more than their substantive obligation in meritorious suits and never pay anything in meritless suits-just as it should be. Furthermore, plaintiffs in meritorious suits do better on average in the investigation equilibrium, and their expected recovery comes closer to their substantive entitlement. ${ }^{132}$

The analysis of the filing equilibrium-in which investigation cost is so high that plaintiffs never investigate-is more ambiguous. One thing is clear: it is never desirable to require investigation when the cost of investigating is so high that a rational plaintiff would not sue if he had to investigate beforehand. But what about requiring investigation short of this limit? The shift to an investigation equilibrium over this range is desirable for its effect on defendants because it eliminates a plaintiff's opportunity to impose strategic costs. It is also possible to show, with the formal analysis, that the shift will have a beneficial effect on total litigation costs, at least when investigation is not too expensive.

The impact on plaintiffs, however, is more ambiguous. The cost of an investigation is high enough in the filing equilibrium that re-

${ }^{131}$ For example, corrective justice theories focus on correcting wrongs to individuals and remedying invasions of an individual's rights. See Kenneth W. Simons, Corrective Justice and Liability for Risk-Creation: A Comment, 38 UCLA L. REV. 113, 125-26 (1990).

${ }^{132}$ Technically, this result holds true only if the cost of an investigation exceeds the cost of filing, which is likely in a mixed equilibrium. The argument is not that all plaintiffs are better off in an investigation equilibrium. If that were true, the ex ante expected value of suit would increase-but it does not. Instead, the argument is that plaintiffs with meritorious suits do better in expected value terms by investigating all the time. In a mixed equilibrium, plaintiffs who do not investigate get a free ridethey benefit from attractive settlement offers made possible by the fact that other plaintiffs take the trouble to investigate. Thus, although the argument is about average effects, it is still consistent with a fairness approach that focuses on individuals. See, e.g., Larry Alexander \& Emily Sherwin, The Deceptive Nature of Rules, 142 U. PA. L. REV. 1191, 1215-16 (1994) (discussing how tradeoffs fit into fairness and rights-based theories). 
quiring it all the time reduces the plaintiff's expected recovery. Whether this is good or bad depends on one's view of what constitutes ideal recovery. On efficiency grounds, the reduction in expected recovery is not likely to be so large that the costs associated with distorted incentives, if any, would overwhelm the combination of litigation cost savings and possible improvement in defendants' incentives. On fairness grounds, however, the ultimate judgment is uncertain. It depends on who should bear the cost of investigating. If it is fair (or at least not unfair) to impose that cost on plaintiffs, then an investigation duty would be justified.

The important point is that the model unequivocally supports a duty to investigate in the mixed equilibrium, where investigation costs are moderate and a failure to investigate clearly unreasonable. Therefore, $I$ focus on this equilibrium in the remaining discussion. ${ }^{133}$ While it is difficult to demonstrate intuitively, ${ }^{194}$ it turns out that efficiency concerns become more serious in this equilibrium as the average expected trial award in a meritorious suit gets smaller. ${ }^{195}$ These results suggest that scarce regulatory resources perhaps should be focused first on those litigation settings with a relatively low average expected trial award in meritorious suits.

\section{Reliability of the Asymmetric Information Models}

Before relying on the predictions of the two asymmetric informa-

${ }^{193}$ At the same time, I recognize that it might also be desirable to address some cases in the filing equilibrium.

${ }^{134}$ The technical reader can verify the results by consulting the Appendix. See Appendix, III.D.3.

${ }^{135}$ The reason is that plaintiffs expect to make more from investigating as the expected trial award increases (since knowing a suit is meritorious then pays a higher return). As a result, plaintiffs investigate more often, and the higher rate of investigation reduces the efficiency loss. To illustrate, consider what happens in the Paul and Susan hypothetical when the expected trial award increases from $\$ 40,000$ to $\$ 90,000$. See Appendix, IV.B.4.b (calculating the results for $\$ 90,000$ ). At $\$ 40,000$, plaintiffs investigate $60 \%$ of the time, and at $\$ 90,000$, they investigate $80 \%$ of the time. Although this increases total investigation costs, it also reduces the number of meritless filings and the number of times a meritorious plaintiff goes to trial. It turns out that total private litigation costs do not change (the opposing effects just cancel), but public litigation costs decline (since the public cost of processing filings and conducting trials is less when there are fewer frivolous filings and fewer trials). Therefore, total private and public litigation costs are lower when the expected trial award is higher. The impact on fairness concerns is more ambiguous, however. The frequency of unjustified wealth transfers decreases from $4 \%$ to roughly $0.8 \%$, but the amount of each transfer increases from $\$ 30,000$ to $\$ 80,000$. 
tion models, it is important to test their reliability. I do this in two parts: first, I examine the internal assumptions of the two models, and then I consider whether there are variables external to the models that might affect their predictions.

\section{Internal Assumptions}

The first thing to note is the assumption common to both models that critical private information cannot be easily communicated to the other side. This assumption is crucial to the informational asymmetry, and it is probably realistic for most situations. In the informedplaintiff model, for example, frivolous as well as legitimate plaintiffs will insist that their suits are legitimate, so defendants will have to discount the value of any information they receive. ${ }^{136}$ Similarly, in the informed-defendant model, defendants have an incentive to claim that the case is meritless whether or not it actually is, so information will be discounted there as well. ${ }^{137}$

The models also implicitly assume that defendants will have difficulty obtaining summary judgment (or dismissal) prior to discovery. This assumption is plausible in the informed-plaintiff model, since defendants do not know before discovery whether a suit is frivolous and so do not know whether summary judgment is warranted. In the informed-defendant model, on the other hand, the defendant knows that the suit is meritless and thus has an incentive to seek summary judgment at the earliest possible moment. Still, the assumption is realistic here too because plaintiffs are often able to put off summary judgment by filing affidavits attesting to the need for discovery. ${ }^{138}$

${ }^{136}$ See Bebchuk, supra note 83, at 442 n.8 (arguing that plaintiffs cannot convince defendants that their suits are meritorious without incurring high costs because the defendant will automatically discount the plaintiff's claims). Moreover, legitimate plaintiffs might fear the loss of a tactical advantage by voluntarily disclosing information early in the case. See id. (arguing that a plaintiff's attempt to lend credence to her claim during settlement negotiations can jeopardize later success should a trial take place). For a general discussion of incentives to disclose information voluntarily, see Shavell, supra note 17.

${ }^{137}$ Furthermore, the assumption that parties are risk-neutral is fairly realistic when the defendant is a large corporation, the plaintiff retains a lawyer on contingency, and the stakes represent a small or moderate fraction of defendant's wealth. See supra note 42 (discussing risk preferences and the effect of contingent fees). In any event, frivolous litigation is likely to be more severe when parties are risk averse because of the greater tendency of risk-averse parties to settle. See POSNER, supra note 42 , at 557 (discussing the effect of variations in risk tolerance on the likelihood of settlement).

${ }^{198}$ See FED. R. CIV. P. 56(f) (permitting courts to grant continuances allowing for 
The models do make a number of unrealistic assumptions, but more realism is not likely to alter their most important qualitative predictions. For instance, it is not essential to assume homogeneous trial success in meritorious suits or perfect accuracy in meritless suits. ${ }^{139}$ When these assumptions are relaxed in the informed-plaintiff model, the basic results remain the same. ${ }^{140}$ Although I am less certain of the effect in the informed-defendant model (because I have not solved the more complex case), the intuition behind the basic results is powerful enough to warrant confidence. ${ }^{141}$

further discovery instead of awarding summary judgment); WSB-TV v. Lee, 842 F.2d 1266, 1269 (11th Cir. 1988) (hinting that courts should rarely grant summary judgment before adequate discovery); John F. Lapham, Summary Judgment Before the Completion of Discovery: A Proposed Revision of Federal Rule of Civil Procedure 56(f), 24 U. MICH. J.L. REFORM 253, 254-55 (1990) (arguing that the tendency of courts to allow additional discovery whenever it might be useful has prevented early dismissal of frivolous suits). Indeed, courts are especially reluctant to grant summary judgment when no discovery has yet taken place and the defendant might have sole possession of relevant evidence. See id. at 273-74 \& n.102. The latter condition is obviously easy to satisfy in the informed-defendant cases, since the defendants are the ones with the private information.

${ }^{139}$ More complex models typically assume a continuum of plaintiff types indexed by probability of trial success. See Bebchuk, supra note 83, at $442-43$ (employing a model that assumes plaintiff has private information about the expected trial award and allows that award to vary continuously); Katz, supra note 17, at 20-25 (analyzing a model in which probability of success varies continuously). These models can take account of trial error by assigning frivolous suits a strictly positive probability of trial success.

${ }^{1+0}$ Frivolous suits are filed, a significant fraction of those suits receive positive settlements, and a large number of legitimate suits go to trial rather than settle due to the presence of frivolous suits. See, e.g., Katz, supra note 17, at 20-25 (demonstrating that these results hold when the probability of success varies continuously). In Katz's continuous type model, however, increasing the stakes does not always exacerbate the frivolous suit problem; instead, the direction of the effect depends on how types are distributed. See id. at 22-25. This distinction, however, may not be all that significant. Parties make choices within the limits of bounded rationality, see supra notes 25-26 and accompanying text, and so they might have trouble figuring out what to do with a continuum of suits. A natural response would be to reduce the continuum to a few discrete categories, such as "strong cases," "moderate cases," "weak cases" and "frivolous cases." See generally Katz, supra note 27, at 248 (making the same general point).

${ }^{141}$ Put simply, the intuition is this: If defendants have information about suit type which they might disclose during settlement negotiations, plaintiffs will rely on those negotiations, at least sometimes, to learn the information. Thus, plaintiffs will not always investigate-unless an investigation is very inexpensive. After all, if plaintiffs did always investigate, they would forfeit the chance of learning more cheaply from defendants, and that would be irrational. Similarly, rational defendants, who anticipate that some plaintiffs will be uninformed, will obviously pool some of the time on the chance that the plaintiff in the particular case is ignorant and can be tricked. The important thing to note is that none of this reasoning depends on strong assumptions about trial success or trial error. 
Nor is it necessary to the informed-defendant model that none of the investigation costs be recoupable later in the litigation. The basic results remain the same, even when investigation saves on discovery, as long as the savings are not too large. ${ }^{142}$ Moreover, it is possible to construct a model in which investigation reduces but does not eliminate uncertainty, without changing the basic results. ${ }^{143}$

Furthermore, relaxing the assumption of zero transaction costs at the settlement stage simply changes the payoffs without any major effect. The assumption that settlement takes place only once, and then always before discovery, is potentially more troubling, but it turns out not to be all that restrictive. For one thing, in view of the high cost of discovery, parties have much to gain by settling early, and the available empirical evidence suggests that many suits conclude without much discovery actually taking place. ${ }^{144}$ Moreover, when our simple models are modified to allow for a second settlement stage after the completion of discovery, the basic qualitative predictions do not change markedly. ${ }^{145}$ Although this second opportunity relieves some

${ }^{142}$ This is a perfectly reasonable proviso. Whether or not plaintiffs investigate, they still must prepare discovery requests and respond to those promulgated by the defendant, and they still must sift through all the documents and other information defendants provide. If investigation saves anything at the discovery stage, it is likely to save mostly on follow-up discovery.

${ }^{143}$ The effect, however, is not as clear for a more complex model that allows continuous investment. One can construct such a model by assuming that investigation produces a signal with more information value the more plaintiffs invest, and that plaintiffs rely on the signal to update their prior beliefs using Bayes's Rule. Cf. Richard Craswell, Precontractual Investigation as an Optimal Precaution Problem, $17 \mathrm{~J}$. LEGAL STUD. 401, 428-31 (1988) (using this approach to construct a non-gametheoretic model of contract investigation). Nevertheless, I tend to think that a discrete model is more realistic than a continuous one given the limits of bounded rationality. See supra note 140 (suggesting that it would be natural for parties to reduce a continuum of suits to a few discrete categories).

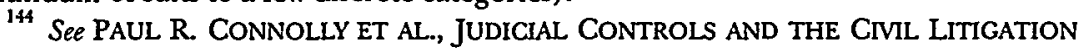
PROCESS: DISCOVERY 36-46 (1978) (noting that few cases involve much discovery activity, but not clearly indicating how much of this is due to early settlement); Linda Mullenix, Discovery in Disarray: The Pervasive Myth of Pervasive Discovery Abuse and the Consequences for Unfounded Rulemaking, 46 STAN. L. REV. 1393, 1432-42 (1994) (reviewing empirical studies that show little discovery in civil cases whether in state or federal court); Early Endings, WALI ST. J., Feb. 11, 1994, at B5 (chart) (reporting a high rate of settlement before completion of pretrial discovery). Moreover, contingency fee arrangements create strong incentives for the plaintiff's attorney to settle early. See Clermont \&. Currivan, supra note 78, at 536 (noting that the economic interests of a lawyer and her client are only partially aligned, and that contingency fee lawyers have a direct economic incentive to "obtain a respectable settlement with relatively slight effort").

${ }^{1+5}$ It is also possible to allow for settlement at more than two stages. See generally 
of the pressure on the defendant, settling early still avoids the potentially high cost of discovery, which generates enough pressure to produce similar equilibrium results. ${ }^{146}$

Furthermore, it is not necessary to have the defendant make the settlement offer. Switching to the plaintiff has different effects in the two different models, and although the analysis is a bit complicated, it can be shown that similar qualitative results obtain. ${ }^{147}$

The take-it-or-leave-it nature of the offer may be the most problematic assumption of all. It makes the model highly tractable, but it abstracts from the give-and-take of settlement negotiations. Bargaining behavior is complex, so complex in fact that the modeling literature is not yet sophisticated enough to capture all the nuances. ${ }^{148}$

Kathryn E. Spier, The Dynamics of Pretrial Negotiation, 59 REV. ECON. STUD. 93 (1992) (showing that multistage bargaining produces a deadline effect when the defendant has private information and the plaintiff makes all the offers).

${ }_{46}$ If defendants always learn whether a suit is meritorious at the discovery stage, the parties have complete information, so all meritorious suits settle at that point. As a result, a new game can be constructed for each of our models, which is identical to the original game except that it terminates immediately after discovery. Since the new game has the same structure as the original game-with discovery rather than trial at the terminal stage- the equilibrium structure is the same, except for somewhat different rates of filing, settlement and litigation. For example, in the informed-plaintiff model, the same two equilibria exist, but the first equilibrium holds less often and offers are made less frequently in the second equilibrium, with the result that discovery costs are wasted in more legitimate suits.

${ }^{147}$ In the informed-plaintiff model, for example, the game becomes a signaling game, since plaintiff communicates information about suit type by his choice of settlement offer. See RASMUSEN, supra note 18, at 249-68 (explaining the phenomenon of signaling). The solution involves many of the same elements that we saw at work in the informed-defendant model (which is also a signaling game). See supra Part V.B. Legitimate plaintiffs make a high demand and frivolous plaintiffs try to pool. Anticipating this strategy, defendants sometimes reject the high demand in order to force separation. As a result, some legitimate suits go to trial, some frivolous plaintiffs sue, and some frivolous suits yield high settlements.

The effect is not as easily discernible in the informed-defendant model. Although defendants can no longer signal by choosing an offer, they can still signal by choosing how to respond to plaintiffs' offers. Accordingly, defendants in meritorious suits still try to pool with defendants in meritless suits, and plaintiffs litigate sometimes when defendants reject (or investigate if that is cheaper) in order to force separation. The result is a similar tripartite equilibrium structure. See Nalebuff, supra note 13, at 205 (showing that uninformed plaintiffs in a model with continuous case strength will make low offers in order to maintain a credible litigation threat).

${ }^{148}$ See, e.g., KREPS, supra note 18, at 91-97, 106-07, 123-28 (exploring the limits of game theory for modeling bargaining behavior). See generally RASMUSEN, supra note 18 , at 275-90 (describing game theory models of bargaining). Indeed, bargaining need not even follow the usual offer/counteroffer format. Parties have access to a wide range of more complex mechanisms, such as settlement escrows, that can enhance bargaining efficiency. See, e.g., Robert H. Gertner \& Geoffrey P. Miller, Settle- 
Even so, there is much to learn from a model that relies on a simple take-it-or-leave-it assumption. For one thing, it is a great improvement over the usual ad hoc approach that ignores strategic behavior. Furthermore, since the basic qualitative predictions of the take-it-orleave-it model depend on informational asymmetry, they may well survive in models that allow for more complex bargaining dynamics. $^{149}$

There are other simplifying features as well. The models focus on two-party lawsuits while litigation can involve more complex party structures. Furthermore, the models ignore the effects of liabilitysharing rules, such as joint and several liability (with or without rights of contribution).$^{150}$ A model, though, must simplify to be useful. And the basic logic of the models discussed here is powerful-a party with private information will seek to exploit the informational asymmetry; his opponent will try to deny him the advantage, and neither party will succeed completely. Thus, frivolous suits will be filed and legitimate suits tried. More complex models will no doubt refine and amplify these predictions, but the results derived here provide a useful foundation for understanding the basic dynamics of frivolous litigation and for guiding regulation.

\section{External Factors}

It remains to be seen whether there are factors external or exog-

ment Escrows, 24 J. LEGAL STUD. 87 (1995) (analyzing a bargaining model which includes a settlement escrow mechanism that facilitates settlement and reduces costs). At the same time, it is worth noting that there is no way to achieve perfect efficiency for all potential trades when information is asymmetric. See Roger B. Myerson \& Mark A. Satterthwaite, Efficient Mechanisms for Bilateral Trading, $29 \mathrm{~J}$. ECON. THEORY 265 (1983) (concluding that it is generally impossible to have an efficient bilateral trading mechanism where information is asymmetric).

${ }^{149}$ Actually, the take-it-or-leave-it assumption might not be as unrealistic as it seems. If likelihood of settlement is high during the pretrial stage, then the parties might experience a take-it-or-leave-it quality to an offer made on the eve of trial. While this is not the same thing as a take-it-or-leave-it offer before discovery, the prospect of a hard offer at a later point can put pressure on earlier offers. See Andrew F. Daughety \& Jennifer F. Reinganum, Settlement Negotiations with Two-Sided Asymmetric Information: Model Duality, Information Distribution, and Efficiency, 14 INT'L REV. L. \& ECON. 283, 287 (1994) (justifying two-stage litigation bargaining models by the pressure of trial and high bargaining costs).

${ }^{150}$ These rules can affect settlements in significant ways. See, e.g., Lewis A. Kornhauser \& Richard L. Revesz, Multidefendant Settlements Under Joint and Several Liability: The Problem of Insolvency, 23 J. LEGal STUD. 517 (1994) (examining the problems that arise in cases involving multiple defendants, one or more of whom is potentially insolvent). 
enous to the models that might affect their predictions. In particular, it is important to examine ways that the parties might deter frivolous suits on their own. We saw that a fighting strategy could act as a deterrent in complete information models. ${ }^{151}$ But this happy result is not possible when information is asymmetric. ${ }^{152}$ For example, plaintiffs still file meritless suits in the informed-defendant model even though defendants fight by always refusing to settle. ${ }^{153}$ Moreover, when defendants do not know which suits are frivolous, as in the informed-plaintiff model, they must fight legitimate suits as well, so fighting is too costly. ${ }^{154}$

Nevertheless, there are two ways for parties to reduce the frivolous suit problem in an asymmetric information model: by relying on reputation, or by using a bond. First, consider the reputation option. ${ }^{155}$ When a plaintiff chooses a lawyer or law firm ${ }^{156}$ with a known reputation for always investigating and filing only meritorious suits, defendants can rely on that reputation to cure any informational asymmetry that blocks early settlement. ${ }^{157}$ Furthermore, lawyers

${ }^{151}$ See supra notes 7479 and accompanying text.

${ }^{152}$ Moreover, unlike the case with complete information, it is not even theoretically possible for prefiling settlement to eliminate all wasted litigation costs when information is asymmetric. Cf. supra note 72 (noting that all frivolous suits should settle before filing where complete information exists). Indeed, this is one advantage of an asymmetric information model: it explains the actual filing of frivolous suits.

${ }^{133}$ In practice, a defendant might also report plaintiff's attorney to disciplinary authorities or retaliate by filing a malicious prosecution action. See Wade, supra note 2, at 437-50 (discussing the tort of malicious civil prosecution). The malicious civil prosecution tort, however, requires that plaintiffs prove malice, which is extremely difficult to do. See id. at $438,444-45$ (concluding that restrictions in some states "render the cause of action essentially unavailable").

${ }^{154}$ In fact, defendants in the informed-plaintiff model already fight to the optimal extent. See supra notes 100-02 and accompanying text. They do not fight more because the cost is too high.

${ }^{153}$ For an extremely useful discussion of reputation mechanisms in litigation, see Gilson \& Mnookin, supra note 56, at 522-34.

${ }^{156}$ I refer to firms as well as lawyers because a reputation market might work better for law firms. See id. at $529 \mathrm{n.55}, 531 \mathrm{n} .60$ (discussing the difficulty of a reputation market developing for individual lawyers and the greater likelihood of one developing for law firms). While an individual lawyer looks forward to a finite litigating life, a firm views litigation as an indefinitely repeated game in which it can gain in the long run by establishing a reputation for filing only legitimate suits. See supra note 77 (discussing the role of indefinite repetition).

${ }^{157}$ For example, in the informed-plaintiff model, a legitimate plaintiff reliably signals an uninformed defendant that suit is legitimate by selecting a law firm with a reputation for filing only (or mostly) legitimate suits. In the informed-defendant model, the plaintiff signals the defendant that she has investigated by selecting a law firm that always (or almost always) investigates. 
should be able to charge plaintiffs a premium for furnishing an early settlement, a premium high enough to induce the lawyer to develop and maintain the necessary reputation. ${ }^{138}$

A reputation mechanism is viable, however, only when conditions are favorable to the formation of a reputation market. ${ }^{159}$ For one thing, defendants must be able to detect frivolous filings. Detection is possible in both the informed-plaintiff and the informed-defendant models, but only some of the time. ${ }^{160}$ Moreover, reading a firm's reputation from its litigation track record is likely to be imprecise, especially if reputation is a matter of degree. ${ }^{161}$ As a result, defendants may find it optimal to excuse the occasional lapse. The upshot is that some filings will be frivolous even under the best of circumstances. ${ }^{162}$

An effective reputation market also requires clients who know the reputations of different law firms and can shop around. Large corporate clients are likely to fit this profile, but individuals are not. The desire to attract corporate business might be enough inducement for some firms to compete over reputation, but not firms, such as the plaintiff's tort bar, that specialize in representing individuals. ${ }^{163}$

Plaintiffs can also reduce the informational asymmetry by using a

${ }^{159}$ Strictly speaking, plaintiffs in our two models are indifferent between settling and going to trial, but this is just an artifact of the take-it-or-leave-it bargaining assumption. In real litigation, the plaintiff will be strictly better off settling early rather than going to trial, so she should be willing to pay an attorney a premium for the greater assurance of settlement. See generally POSNER, supra note 42, at 554-60 (describing the general theory of settlement).

${ }^{559}$ See Gilson \& Mnookin, supra note 56, at 546-50 (analyzing factors such as the size of the legal community, complexity of the legal market, and geographical variance in "legal culture," which influence the likelihood that a reputation market will develop). Moreover, an attorney will invest in reputation only to the point where the marginal benefit equals the marginal cost. In the informed-defendant model, this condition can sometimes undermine incentives to acquire reputation in a mixed equilibrium.

${ }^{160}$ For example, defendants know a suit is frivolous in the informed-plaintiff model only when they refuse to settle, since in that case, frivolous plaintiffs always drop and legitimate plaintiffs always litigate.

${ }_{161}$ See Gilson \& Mnookin, supra note 56, at 539-40, 548-49.

162 This result is likely to be reinforced by the possibility of mistakes and occasional attorney defection from a firm's litigation policy. Of course, lapses might be very rare if defendants lost all faith in a firm's reputation upon observing a single lapse. However, defendants are not likely to do this because they still benefit from making high offers to a firm that lapses only occasionally.

${ }^{163}$ This might help to explain the concern about frivolous personal injury tort suits. See generally Michael Selz \& Jeffrey A. Tannenbaum, Scared of Lazusuits, Small Businesses Applaud Reform, WALL ST. J., Mar. 13, 1995, at B1 (highlighting business concerns about frivolous tort suits). 
bonding strategy. ${ }^{164}$ The bonding alternative is a way for a truthful party to impose costs on a party who falsely claims that a suit is legitimate (as in the informed-plaintiff model), or that an investigation has been conducted (as in the informed-defendant model). To demonstrate bonding, I will focus on the informed-plaintiff model and use the John and Mary hypothetical. ${ }^{165}$ Assume that John's suit is legitimate, that the $\$ 10,000$ total litigation costs are split evenly between discovery $(\$ 5000)$ and trial $(\$ 5000)$, and that discovery reveals suit type perfectly. Furthermore, assume that courts are perfectly accurate at the pretrial stage.

Eager to persuade Mary that his suit is legitimate, John says something like the following:

I am a legitimate plaintiff. I know that you don't believe me because I would say the same thing if I were frivolous. But let me prove it to you. I will commit to paying you $\$ 20,000$ in any of the following three circumstances: (1) if I drop my suit voluntarily except as part of a settlement; (2) if my suit is ever dismissed involuntarily; or (3) if summary judgment is ever granted in your favor. You and I both know that if I am legitimate, I will never actually have to pay the $\$ 20,000$ bond. A legitimate plaintiff is better off going to trial than dropping, and since the court is perfectly accurate at the pretrial stage, you will never obtain an involuntary dismissal or summary judgment. On the other hand, if I am frivolous, I will have to pay the $\$ 20,000$ bond if you refuse to settle, because in that case I would drop rather than litigate further. After all, it costs a frivolous plaintiff $\$ 26,000$ to go through discovery, ${ }^{166}$ but only $\$ 21,000$ to drop. ${ }^{167}$ You must admit then that it is much more likely for a legitimate plaintiff to enter into this deal than a frivolous one. It follows that a $\$ 20,000$ bond will screen out a lot of frivolous suits, and so it makes sense for you to offer the settlement more frequently, being more con-

${ }^{164}$ On bonding mechanisms generally, see Oliver E. Williamson, Credible Commitments: Using Hostages to Support Exchange, 73 AM. ECON. REV. 519 (1983) (discussing mechanisms to ensure commitment).

${ }_{165}$ See supra Part V.A.1.

${ }_{166} \$ 1000$ (filing cost) $+\$ 5000$ (discovery cost) $+\$ 20,000$ (bond) $=\$ 26,000$.

$167 \$ 1000$ (filing cost) $+\$ 20,000$ (bond) $=\$ 21,000$. 
fident that your opponent is legitimate..$^{16 s}$

$* * * *$

John's logic is impeccable, and Mary, being rational, must agree. In this simple situation, the bond, a conditional payment of $\$ 20,000$, creates no additional risk for John because he has a legitimate suit, but it creates considerable risk for any frivolous plaintiff who tries to mimic. This will not deter all frivolous plaintiffs in equilibrium, but it will deter a significant number and thus make defendants more willing to settle. ${ }^{169}$ As the amount of the bond rises, a greater number of frivolous plaintiffs are deterred from filing and defendants become even more willing to settle. Legitimate plaintiffs benefit from the enhanced prospect of settlement, and this benefit gives them an incentive to employ the bonding strategy.

The basic mechanism is similar in the informed-defendant model, except that the bond penalizes uninformed plaintiffs who falsely claim to have investigated. In both models, bonding acts as a private analogue to Rule 11, a way for private parties to create a sanctioning system by contract. ${ }^{170}$ There are limits to the utility of this device, however. The bond is costless only on the unrealistic assumption that courts never make mistakes. If instead courts occasionally grant summary judgment in legitimate suits, then truthful plaintiffs, like John, expect to pay the bond sometimes, and this reduces the value of suit. ${ }^{171}$ As the amount of the bond increases, the marginal cost in terms of reduced value rises, while the marginal deterrence benefit

109 This last step in the argument generalizes from John and Mary. In effect, John is saying to Mary: "If you always accept the $\$ 20,000$ bond, then proportionately more legitimate plaintiffs will offer it than will frivolous plaintiffs, so you will be able to use the bond as a signal (albeit an imperfect one) that suit is legitimate."

${ }^{169}$ Suppose the fraction of potential frivolous suits is $50 \%$. It can be shown that a $\$ 20,000$ bond reduces the frequency of frivolous filings from $2 / 3$ to $2 / 5$, or by about $27 \%$, and increases the frequency with which defendant makes the high offer from $1 / 30$ to $21 / 50$, or by about $39 \%$. For formulae that can be used to calculate these results, see Katz, supra note 17, at 19-20 (analyzing the effect of a deposit in the informed-plaintiff model, which is equivalent to a bond when courts are perfectly accurate).

${ }^{170}$ Mathematically, the effect is precisely the same as a Rule 11 sanction that is perfectly enforced.

${ }^{171}$ For example, suppose courts in our John and Mary hypothetical erroneously grant summary judgment in legitimate suits $10 \%$ of the time and suppose they always do so immediately after discovery. If John does not give a bond, the expected value of his legitimate suit after filing is: $0.9 \times(0.8 \times \$ 50,000-\$ 10,000)-0.1 \times \$ 5000=\$ 26,500$. On the other hand, if John gives a bond in the amount of $\$ 20,000$, he anticipates actually paying it $10 \%$ of the time, so the expected value of his suit after filing is: $0.9 \times(0.8 \times \$ 50,000-\$ 10,000)-0.1 \times(\$ 5000+\$ 20,000)=\$ 24,500$. 
declines. At some point, marginal cost just equals marginal benefit, and plaintiffs will not bond for any greater amount. Thus, judicial error caps the optimal size of the bond and so limits the effectiveness of a bonding strategy. ${ }^{172}$

\section{Summary}

Before proceeding with the regulatory analysis, it is useful to list the most salient conclusions of the two asymmetric information models:

- Frivolous suits are most likely to occur in litigation settings with asymmetric information, where one party has critical private information about liability that he cannot easily communicate in a credible way (and especially when summary judgment is difficult to obtain before discovery).

- Although a meritless suit is always frivolous in the informedplaintiff model, it is most clearly frivolous in the informed-defendant model when the conditions for a mixed equilibrium are satisfied; that is, when investigation costs are moderate.

- Frivolous litigation is problematic because it generates wasted litigation costs and unjustified wealth transfers.

- A reputation market can reduce these problems, but it is likely to be least effective in those practice settings that feature a specialized plaintiff's bar representing mostly individual rather than corporate clients.

- Bonding can also be useful, but it is likely to be least effective and least desirable from a social point of view when the risk of judicial error at the pretrial stage is relatively high-especially the risk of mistaken grants of summary judgment in meritorious suits.

The two models also produce different, and sometimes inconsistent, predictions:

- Most significantly for our purposes, the two models make opposite predictions about how frivolous suit problems vary with expected trial award in a meritorious suit. In the informed-plaintiff model, the problems are likely to be most severe in those litigation settings where

${ }^{172}$ The risk of an erroneous denial of summary judgment also reduces the utility of a bonding strategy by reducing the chance that a lying plaintiff would actually have to pay the bond. Truthful plaintiffs can offset this effect to some extent by agreeing to pay the bond even if they lose at trial. But with trial error, such a strategy is likely to reduce the value of suit considerably-so much so, in fact, that plaintiffs will rarely be willing to employ it. 
the expected trial award is relatively high on average. ${ }^{173}$ By contrast, in the informed-defendant model (focusing on the mixed equilibrium), the problems are likely to be most severe where the expected trial award is relatively low. ${ }^{17}$

- Furthermore, the most salient policy concern-litigation costs, unjustified wealth transfers, or both-can differ between the two models for a fixed fraction of potential meritless suits. For example, in the informed-plaintiff model, a relatively small fraction produces an equilibrium in which the only serious concern is unjustified wealth transfers (since all frivolous suits settle early), but in the informeddefendant model, a small fraction can support an equilibrium in which both litigation costs and unjustified wealth transfers are serious concerns. ${ }^{175}$

\section{REGULATORY IMPLICATIONS}

We now turn to the question of what this positive account of frivolous litigation tells us about regulation. The goal of any regulatory scheme, whether it involves strict pleading, penalties or judicial screening, is, loosely stated, to minimize the problems of frivolous litigation without creating too many new problems along the way. ${ }^{176}$ It is important to see what this goal does not involve. It does not seek to eliminate all frivolous suits whatever the cost, nor does it seek to avoid all adverse effects on meritorious suits. The goal, instead, is to strike a sensible balance between the benefit of reducing frivolous suits and the regulatory costs.

One needs a normative standard to strike this balance. It is tempting to conclude that the use of formal models entails a commitment to efficiency. But this is mistaken. Formal analysis, as posi-

${ }^{173}$ See supra note 102 and accompanying text.

${ }^{174}$ See supra note 135 and accompanying text. These predictions depend somewhat more strongly than the others on the modeling assumptions, but they still warrant enough confidence to justify cautious reliance.

${ }^{173}$ The nature of the unjustified wealth transfer also differs. In the informedplaintiff model, wealth transfers reward meritless plaintiffs and never benefit defendants, whereas in the informed-defendant model, wealth transfers reward defendants in meritorious suits and never benefit plaintiffs. Furthermore, it is worth noting that while potential meritless suits always create problems in the informed-plaintiff model, no matter how large a fraction they represent, they create no problems at all in the informed-defendant model when their fraction is very large (since then suit is NEV unless plaintiff investigates). Compare Appendix, II with Appendix, III.A.

176 I state the goal in this way in order to allow for all possible normative theories, not just efficiency. 
tive theory, is not necessarily tied to normative law and economics. Indeed, formal modeling can be useful for any normative theory that counts consequences, including rights-based theories that make a person's rights depend to some extent on the consequences that flow from their exercise, ${ }^{177}$ and fairness theories that measure fairness by reference to distributive effects. ${ }^{178}$ In the following discussion, I focus on the familiar efficiency-based theory that views adjudication as an instrument for applying the substantive law accurately to create efficient incentives ex ante. ${ }^{179} \mathrm{But}$, I also refer at times to implications for a rights-based theory that views adjudication in terms of enforcing individual rights.

A word of caution at the outset: Given the limitations of gametheoretic models, ${ }^{180}$ one must be careful when making policy recommendations. Yet, so long as one refrains from overly broad claims, the insights derived from modeling can be extremely useful to regulation. This is especially true of litigation reform today, which is in great need of a more sophisticated approach to predicting strategic effects. Indeed, the effort will be worthwhile if it identifies questions and concerns that deserve more careful attention from policymakers. ${ }^{181}$

177 For example, if one believed that each party had a right to the outcome that would result if all parties were fully informed, then one would have to recognize a violation of that right each time a meritorious plaintiff dropped (as happens in the informed-defendant model). See, e.g., RoNald DwOrkIN, Principle, Policy, Procedure, in A MATTER OF PRINCIPLE 72 (1985) (describing a more complex rights-based theory that still counts consequences).

${ }^{178}$ See, e.g., Robert G. Bone, Statistical Adjudication: Rights, Justice, and Utility in a World of Process Scarcity, 46 VAND. L. REV. 561, 617-50 (1993) (reviewing the standard arguments used to defend aggregation against process-oriented objections and then examining the distributional problem in the sampling context).

${ }^{179}$ See, e.g., POSNER, supra note 42, at 549 (describing the economic goal of the procedural system as minimizing costs); Robert D. Cooter \& Daniel L. Rubinfeld, Economic Analysis of Legal Disputes and Their Resolution, 27 J. ECON. LITERATURE 1067, 108687 (1989) (summarizing the economic approach to procedural analysis).

${ }^{180}$ See, e.g., KREPS, supra note 18, at 91-132 (discussing problems with gametheoretic methods).

${ }^{181}$ It might seem that some of the points I discuss in this Part could have been derived without the formal models. This is true for some, but it is not true for many of the most important insights. The problem is that once the intuition is understood, it often seems as if the point could have been derived straightforwardly through the same intuitive logic used to explain it. As it turns out, however, we often need the rigor of a formal analysis to bring the intuition to light and to understand its implications and limits fully. In this way, game theory has a tendency to eat its own tail: game-theoretic tools are extremely useful to understand the nature of complicated problems, but once intuitive understanding is achieved, those tools are often no 


\section{A. Is Any Public Regulation Desirable?}

\section{The Seriousness of the Problem}

The results of our formal analysis neither rule out nor clearly confirm a serious frivolous suit problem. However, they do indicate that if problems exist, they are likely to arise in situations quite different from those emphasized in the more sensational popular accounts. Those accounts tend to focus on cases of complete information, in which the plaintiff's attorney manages to extort a nuisance settlement from a defendant who knows the suit is meritless and is outraged by the filing. By contrast, the formal models emphasize the effect of asymmetric information. ${ }^{182}$ Yet, it is still difficult to assess the severity of the frivolous suit problem even in asymmetric information cases, because of the availability of self-help measures such as reputation markets and bonding strategies. ${ }^{18 s}$

Given this uncertainty, we cannot rule out the desirability of regulation altogether, but neither can we be confident that extensive regulation is warranted. We need much more empirical information, and the formal analysis can help in at least two ways.

First, although it is difficult to use rigorous empirical methods because of the problems with measuring frivolous suits directly, it is still possible to obtain some information from reports of widely-shared experience in practice communities. This kind of information is not altogether reliable, but it is not totally worthless either. To the extent that the information confirms predictions generated formally from the models, it provides support for those predictions and for the predictive power of the models more generally.

Second, to the extent one has confidence in a model's predictions, those predictions can set an agenda for useful empirical work. For example, the models in this Article identify systematic relationships between the most problematic effects of frivolous litigation and variables that are easier to measure: typical information structure, opportunities for credible transmission of private information about the merits, judicial attitudes toward summary judgment before and after discovery, the use of bonding strategies, and the structure of at-

longer needed-and it may seem as if they were never needed at all. For a similar observation, see $i d$ at 88 (noting that game theory does best at clarifying latent intuitions and pushing those intuitions into more complex situations).

${ }^{162}$ See supra Part V.

${ }^{183}$ See supra notes $155-72$ and accompanying text. 
torney markets (especially conditions for acquisition of reputation). Casual empiricism, for instance, suggests rough sortings of lawyers according to their reputation for reasonable litigation conduct, at least in some practice settings. ${ }^{184}$ More rigorous empirical studies might identify factors that facilitate this kind of sorting process, such as the size of legal practice communities, the frequency of interaction among lawyers, and the nature of the clientele. ${ }^{185}$ With these data in hand, one can use the models to identify areas of potential concern without the need to count frivolous suits directly. Indeed, it might even be possible to discover ways to facilitate private solutions such as reputation markets. ${ }^{186}$

\section{The Need for a General Norm}

Whether or not enforcement is a good idea, one type of regulation is absolutely necessary: promulgation of a general rule, such as Rule 11 (and 28 U.S.C. $\S 1927$ ), that defines the domain of permissible litigation. It may seem odd to propose a rule without also guaranteeing an official means of enforcement, but enforcement is not always necessary to a rule's efficacy. ${ }^{187}$ People sometimes obey rules in the absence of sanctions simply because they believe following rules is the right thing to do, or because they agree with the principle that the particular rule expresses. Moreover, rules can be enforced informally through reputation. Indeed, a rule prohibiting frivolous suits might encourage the formation of reputation markets with beneficial deterrence effects. ${ }^{188}$

To achieve these objectives, however, such a rule must express its

${ }^{184}$ See, e.g., Gilson \& Mnookin, supra note 56 , at 541-46 (describing a sorting between cooperative and hard-ball litigators in family law practice).

${ }^{185}$ See id. at 546-50 (suggesting some of these factors); see also Marshall et al., supra note 12, at 975-81 (listing factors affecting Rule 11 activity).

${ }^{180}$ See, e.g., Gilson \& Mnookin, supra note 56, at 550-64 (making a similar suggestion in the context of analyzing incentives to overinvest in litigation).

${ }^{187}$ Furthermore, foundational rules like this one have a constitutive function that gives them value whether or not people actually comply. Procedural rules in effect constitute a system of civil adjudication, much as the rules of baseball constitute the game. On the difference between constitutive and regulative rules, see John Rawls, Two Concepts of Rules, 64 PHIL. REv. 3, 18-29 (1955).

${ }^{188}$ For example, a relatively clear and public definition of frivolousness could make it easier to evaluate a lawyer's reputation. See supra note 162 (noting the problem of noisy signals that make identifying lawyer cooperation very difficult). Furthermore, it might also serve as a focal point to attract parties to a reputation equilibrium. See RASMUSEN, supra note 18, at 28-29 (explaining focal points). 
prescriptive choices as clearly as possible. The current version of Rule 11 falls short of this ideal; it provides litigants, lawyers and judges with little guidance about how to determine whether a suit is frivolous. ${ }^{189}$ To illustrate, consider the critical question of when a lawyer's prefiling investigation should be deemed inadequate. ${ }^{100}$ Rule 11 states the standard in vague language: plaintiffs and their attorneys have a duty to conduct "an inquiry reasonable under the circumstances." $191 \mathrm{Sec}$ tion (b) (3) expands on this basic requirement somewhat by allowing factual allegations without evidentiary support when they are "specifically so identified" and "are likely to have evidentiary support after a reasonable opportunity for further investigation or discovery." ${ }^{192}$ Yet this section is also qualified by the general requirement of a "reasonable inquiry." Courts have created factors to be considered on a case-by-case basis, but these factors are general and conclusory and their application is highly fact-dependent. ${ }^{194}$

${ }^{189}$ When 1983 Rule 11 was in effect, one frequently read or heard complaints of vagueness, inconsistency and unpredictability. See, e.g., William W. Schwarzer, Rule 11 Revisited, 101 HARV. L. REV. 1013, 1015-17 (1988) (citing inconsistent applications of 1983 Rule 11 as evidence of its unpredictability); Note, Plausible Pleadings: Developing Standards for Rule 11 Sanctions, 100 HARV. L. REV. 630, 639-42 (1987) (discussing the "uncertainty over when a legal argument is sufficiently plausible" to avoid Rule 11 sanctions). This problem still exists with the 1993 version.

${ }^{190}$ The current version of Rule 11 also provides little guidance for determining when a weak legal argument lacks merit. See FED. R. CrV. P. 1l(b)(2) \& advisory committee's note. One way to furnish more guidance would be to use modifiers, such as "strong," "reasonable" or "rational," to indicate the kind of support in established precedent a novel legal argument must have. Moreover, different modifiers could be used for different kinds of cases, perhaps allowing weaker support in civil rights suits to reflect the special importance of creative argument in the constitutional field. See supra note 45 and accompanying text (discussing a civil rights example).

${ }^{191}$ FED. R. CIV. P. 11 (b); see also FED. R. CrV. P. 11 (1983) (requiring "reasonable inquiry").

${ }_{192}$ FED. R. CIV. P. 11 (b) (3).

${ }^{199}$ See FED. R. CIV. P. 11 advisory committee's note (1993) (cautioning that (b) (3) "does not relieve litigants from the obligation to conduct an appropriate investigation into the facts that is reasonable under the circumstances").

${ }^{194}$ One court listed the factors as follows:

[W] hether the signer of the documents had sufficient time for investigation; the extent to which the attorney had to rely on his or her client for the factual foundation underlying the pleading, motion, or other paper; whether the case was accepted from another attorney; the complexity of the facts and the attorney's ability to do a sufficient pre-filing investigation; and whether discovery would have been beneficial to the development of the underlying facts.

Brown v. Federation of State Med. Bds., 830 F.2d 1429, 1435 (7th Cir. 1987), quoted in Kraemer v. Grant County, 892 F.2d 686, 689 (7th Cir. 1990). Some of these factors 
Although reasonableness must turn to some extent on the facts of each case, the formal analysis points the way to a more helpful formulation of the general standard. According to the informed-defendant model, a prefiling investigation is most strongly justified in the mixed equilibrium where plaintiffs investigate sometimes but not always. ${ }^{195}$ This suggests a way to express the reasonableness standard in Rule 11: A prefiling investigation is reasonable if it is the kind of investigation a rational plaintiff would undertake when her only other alternative for learning whether her suit has merit is to conduct discovery.

This formulation, in effect, forces the plaintiff's attorney to ignore the possibility of obtaining information about suit type from the defendant's settlement offer. The reason for eliminating this option is that it is responsible for the strategic interaction that generates high social costs in the mixed equilibrium. ${ }^{196}$ Moreover, the formulation defines a perspective from which reasonableness can be assessed-the perspective of the rational plaintiff who knows that if she does not investigate she must make all significant litigation decisions before discovery without knowing whether she has a frivolous suit. This is important. The reference to rationality identifies a motivation for choice-individual utility maximization-and the focus on the rational plaintiff rather than the rational attorney brackets agency problems.

The standard instructs a judge or lawyer to compare the cost of investigation with the average cost of obtaining the same information by filing and litigating to the discovery stage, discounted by the likelihood of a meritless suit. This is the same calculation that a rational plaintiff would perform when comparing prefiling investigation to discovery as alternative means for learning the suit type. Moreover, it follows from the importance of predictability and cost-minimization that the calculation should be done for general categories of cases on the basis of average values, rather than for each individual suit. ${ }^{197}$

track those mentioned in the advisory committee note to 1983 Rule 11 . See FED. R. CIV. P. 11 advisory committee's note (1983) (noting that courts should consider "such factors as how much time for investigation was available to the signer; whether he had to rely on a client for information as to the facts ...; whether the pleading ... was based on a plausible view of the law; or whether he depended on forwarding counsel or another member of the bar").

${ }^{195}$ See supra Part V.B.3.

${ }_{196}^{196}$ See supra note 129 and accompanying text.

197 See generally Louis Kaplow, Rules Versus Standards: An Economic Analysis, 42 DUKE L.J. 557, 568-96 (1992) (discussing how predictability and cost-minimization affect the choice between rules and standards). Moreover, by using my suggested formulation, 


\section{B. Targeted Versus Uniform Enforcement}

I now turn to the issue of enforcement. The critical questions here are whether the general norm prohibiting frivolous suits should be enforced at all, and if it should, in what litigation contexts and by what sort of device. The answers to these questions depend on the balance of benefits and costs for different enforcement schemes. One might adopt no enforcement at all, a uniform enforcement scheme, or a targeted scheme that varies with case type. The choice among these alternatives requires a much more detailed analysis than is possible in this Article. Nevertheless, the formal models shed light on the choice between the second and the third options: uniform versus targeted enforcement. A uniform approach works best when the nature of the problem is relatively homogeneous across different litigation settings. ${ }^{198}$ When the problem varies substantially from setting to setting, however, it can be more difficult to design a single, uniform scheme that works well everywhere. An effective approach in one setting might generate high error and administrative costs in another. Under these circumstances, targeted enforcement tuned to the differences can sometimes improve on the cost-benefit balance.

The formal analysis strongly suggests that frivolous litigation is a highly variable phenomenon. The nature and seriousness of the problems depend on a number of factors that vary from case to case: information structure, the fraction of potential frivolous suits, the average strength and stakes of meritorious suits, the existence of

courts could even develop rules establishing investigation requirements for different kinds of suits. For example, if a large enough fraction of medical malpractice suits were meritless, it might make sense to adopt a general rule that all plaintiffs must obtain, before filing, an expert opinion from an independent specialist that negligence could have caused their injury. C . Wagner v. Allied Chem. Corp., 623 F. Supp. 1407, 1411-12 (D. Md. 1985) (denying Rule 11 sanctions where the attorney for a products liability plaintiff consulted an expert and interviewed his clients before filing). The average cost of getting the opinion would probably be less than the expected cost of filing and discovery in a meritless suit, assuming the fraction of meritless suits was large. Furthermore, any such rule could be made presumptive if it was important to take account of extenuating circumstances. Per se rules are probably superior to presumptive rules, however, since exceptions undermine predictability and invite litigation.

198 See, e.g., Isaac Ehrlich \& Richard A. Posner, An Economic Analysis of Legal Rulemaking, 3 J. LEGAL STUD. 257, 270, 273 (1974) (noting the relevance of homogeneity to over- and under-inclusion and the optimal degree of specificity); Kaplow, supra note 197, at 586-96 (discussing the costs and benefits of greater complexity in rule formulation). The work on rule specificity has tended to focus on the question of the appropriate liability norm rather than the best mode of enforcement. However, many of the same considerations apply to both questions. 
reputation markets, and the availability of bonding strategies. If this variance is substantial enough, a targeted approach might be superior to uniform enforcement.

For example, contract disputes are more likely than many other kinds of litigation to manifest complete (or almost complete) information about liability, especially when the contractual relationship involves periodic opportunities to monitor performance. ${ }^{199}$ This means that frivolous suit problems in the contract setting are not likely to be as serious as in other litigation contexts. Moreover, such problems are likely to be even less significant for long-term contract relationships, because relation-specific investments give parties incentives to act reasonably in order to maintain the relationship. ${ }^{200}$ These predictions are consistent with the results of one empirical study that found less Rule 11 activity in contract cases than in any other case types surveyed. ${ }^{201}$ If further empirical research were to confirm these predictions and if it turned out that enforcement was very costly, then it might be best to leave the norm unenforced in this context.

On the other hand, the formal models predict potentially serious problems in litigation settings with asymmetric information, such as products liability, medical malpractice and securities fraud. Moreover, models also help to set enforcement priorities within these categories by identifying the particular kinds of cases likely to have the worst problems. ${ }^{20}$

Even so, the choice between a uniform and a targeted approach must take account of the costs of targeted enforcement, including the cost of designing and promulgating the overall scheme and the cost of enforcing it in particular cases. ${ }^{203}$ As to the first type of cost, one

${ }^{199}$ See, supra, the discussion in the beginning paragraphs of Part IV, which uses a contract case as an example of complete information.

${ }^{200}$ Further, since the parties depend on one another's continuing goodwill, each can penalize the other for a frivolous filing by withholding cooperation in the future. See generally ROBERT COOTER \& THOMAS ULEN, LAW AND ECONOMICS 243-47 (1988) (reviewing the special features of long-term contracts).

Sol See Marshall et al., supra note 12, at 966-67, 969 (examining cases under 1983 Rule 11).

202 For example, we saw that problems are likely to be most severe in those informed-plaintiff cases where the expected trial award in meritorious suits is relatively high, and in those informed-defendant cases where the expected trial award in meritorious suits is relatively low. See supra notes 102,135 and accompanying text.

${ }^{203}$ See, e.g., Ehrlich \& Posner, supra note 198, at 267-71 (summarizing costs and benefits of greater precision in rule formulation); Kaplow, supra note 197, at 568-86 (discussing the costs and benefits of ex post judicial determinations versus ex ante rule formulation). 
must compare the promulgation costs of a targeted approach with those of a uniform approach. In this regard, it is significant that rulemakers committed to designing an optimal system will have to collect much of the same empirical information whichever approach they choose. After all, even under a uniform approach, optimal selection of an enforcement device-such as strict pleading, penalties, screening and the like-will have to take account of the nature and source of frivolous suit problems. To be sure, promulgation costs will probably be somewhat higher under a targeted approach, but so too will the benefits.

The second type of cost is incurred at the enforcement stage. One potentially significant component is the cost of classifying actual cases into the distinct categories of the targeted scheme. For example, a targeted rule that imposed sanctions in products liability cases only when reputation markets were "ineffective" would surely invite a lot of litigation over the effectiveness of reputation in particular contexts, as well as strategic maneuvering to take maximum advantage of the rule's vagueness. If the resulting administrative costs were high enough, they could overwhelm the benefits of the rule. Thus, a targeted approach should define its case categories as clearly as possible, and when clarity is not possible, a uniform approach (or at least a targeted approach that ignored the particular distinction) might be preferable.

It is also important to bear in mind that any evaluation of enforcement costs and benefits depends on the reasons for condemning frivolous suits. For example, unjustified wealth transfers are the main concern in the informed-plaintiff model when the proportion of potential frivolous suits is relatively low. ${ }^{204}$ Whether this is a sufficient reason to regulate, however, depends on the normative standard for evaluating frivolous suits. If the standard is efficiency, wealth transfers are troubling only to the extent that they distort incentives and then only if the benefit of correcting for the distortion justifies the enforcement cost. Given the many random factors that can affect case outcome as well as the potentially high cost of enforcement, the average wealth transfer would have to be very large indeed to warrant regulatory intervention.

On the other hand, if the standard is some version of a rights-

${ }^{204}$ See supra notes 97-98 and accompanying text (explaining that, under these circumstances, defendants will offer all plaintiffs the settlement amount that a legitimate plaintiff would accept). 
based theory, even relatively small transfers might be cause for concern, since any unjustified transfer deprives some party of her full substantive entitlement. ${ }^{205}$ Although considerations of cost necessarily impose practical limits, those limits coexist uneasily with the idea of rights. ${ }^{206}$ As a result, a rights theorist will normally demand more by way of cost to justify regulatory inaction. ${ }^{207}$

If some kind of targeted enforcement is optimal, as the foregoing analysis suggests, then congressional efforts such as the Attorney Accountability Act, ${ }^{208}$ designed to reinstate the across-the-board sanctions of 1983 Rule 11, are misguided. Instead, Congress should study the strategic dynamics of frivolous litigation in different settings and assess the desirability of targeted enforcement measures. An example of a targeted approach is the Private Securities Litigation Reform Act of $1995,{ }^{209}$ which adopts a special enforcement scheme for frivolous securities class actions.

\section{The Selection of an Enforcement Device}

The formal analysis also helps with the selection of an appropriate enforcement device. Although it is not possible to give a complete analysis here, I will briefly describe what the models teach about the desirability of two popular devices ${ }^{211}$-strict pleading and penalties-

${ }^{205}$ Some corrective justice theories belong in this category. See, e.g., Bone, supra note 178, at 605-15 (discussing the implications of corrective justice theory).

${ }^{206}$ This is because a rights-based theory gives claims based on individual rights priority over claims based on maximizing overall utility or furthering aggregative social goals. See, e.g., RONALD DWORKIN, TAKING RIGHTS SERIOUSLY 90-100 (1977) (distinguishing rights from collective goals); THOMAS NAGEL, MORTAL QUESTIONS 11216, 131-33 (1979) (comparing the moral logic of rights and utilitarianism). In theory at least, a rights bearer can demand that her individual right be satisfied even if the cost of doing so substantially reduces aggregate welfare.

${ }_{207}$ See Bone, supra note 178 , at 594,598-605 (emphasizing that to a rights theorist, arguments based on general cost savings alone will not justify the deprivation of a right).

${ }_{208}^{20}$ H.R. 988, 104th Cong. (1995).

${ }^{209}$ Pub. L. No. 104-67, 109 Stat. 737 (codified in scattered sections of 15 U.S.C.).

${ }^{210}$ This scheme relies on strict pleading, mandatory penalties and restrictions on representation. See 15 U.S.C.A. $\$ \S 78 \mathrm{u}-4$ (b) (2) (strict pleading), 77z-1(c) (mandatory penalties), 77z-1 (a) (2), (3) (restrictions on representation) (West Supp. 1996).

${ }_{211}$ I do not discuss damage caps or fee shifting-the former because it is not as popular as other devices for deterring frivolous suits, and the latter because the analysis is too complicated. Yet, it is worth mentioning that damage caps will do nothing at all in those asymmetric information cases that already have moderate expected damage awards. It might even make things worse in the informed-defendant cases if frivo- 
and then make a case for a third and more promising approachearly judicial screening. I analyze each device assuming that it is the only one implemented. Any combination can be evaluated according to the costs and benefits of each of its separate components.

\section{Strict Pleading}

The standard pleading rule in federal court is notice pleading, which requires very little factual detail. ${ }^{212}$ Concerned that such a generous rule invites frivolous suits, courts and commentators have proposed stricter pleading requirements that mandate more factually specific allegations. ${ }^{213}$ Proponents of strict pleading argue that a plaintiff who is required to allege specific facts will have to spend more to file (and therefore be discouraged from bringing weak suits), will be forced to know more about the case before filing (and therefore be more likely to recognize its weakness), and will make the merits transparent through his allegations (and therefore facilitate early dismissal of meritless suits). These benefits turn out to be problematic, however, and the case for strict pleading becomes much weaker than commonly supposed when the results of the formal analysis are taken into account.

First, consider the effect of a strict pleading requirement in the informed-plaintiff model. When plaintiffs know their suits are frivolous and file anyway, they have no reason to investigate under a strict pleading rule. They will simply fabricate the necessary allegations. Moreover, fabrication should be quite easy, since the plaintiff runs little risk of tipping off an uninformed defendant that he is lying. Therefore, the only conceivable way strict pleading can affect frivolous litigation in the informed-plaintiff model is indirectly: strict pleading forces legitimate plaintiffs to investigate more in order to plead with greater specificity and this increases their filing costs. However, so long as legitimate plaintiffs are still willing to sue, simply

lous suit problems increase as the expected trial award declines. See supra note 135 and accompanying text (explaining that efficiency losses increase as the expected trial award gets smaller). Moreover, when information is asymmetric, fee-shifting is not likely to help as much as its proponents claim, especially in the informed-plaintiff cases. See, e.g., Katz, supra note 17, at 17-19 (analyzing the effect of fee shifting rules on frivolous litigation in the informed-plaintiff model).

212 See Leatherman v. Tarrant County Narcotics Intelligence \& Coordination Unit, 507 U.S. 163, 168 (1993) (refusing to apply a more stringent pleading rule); Conley v. Gibson, 355 U.S. $41,47-48$ (1957) (establishing the notice pleading standard).

${ }^{215}$ See sources cited in supra note 4. 
increasing the filing cost has no effect whatsoever on the number of frivolous filings or the settlement rate. This is because a legitimate plaintiff's filing cost cannot affect the settlement offer, since filing costs are already paid by the time the settlement stage is reached. ${ }^{214}$

The analysis is a bit more complicated if strict pleading ends up shifting costs from the discovery and trial stages to the filing stage, instead of just increasing the cost of filing. ${ }^{215}$ This would be the case, for example, if more investigation reduced the need to conduct discovery later in the lawsuit. One can show that the reduction in costs at the later stages increases the size of the settlement offer, which reduces the settlement rate. While this also reduces the number of frivolous suits, it increases the total trial costs, resulting in an increase in total litigation costs. ${ }^{216}$ Thus, strict pleading is not likely to help, and may even hurt, when plaintiffs are informed.

The results are more ambiguous in the informed-defendant cases. First, a lawyer pressed for time might be willing to file without knowing whether the suit is frivolous, but might balk at making up allegations he knows are fictional. Any lawyer willing to make allegations without support in a notice pleading system must have questionable ethics to begin with, but it seems likely that at least some of those lawyers would be ethical enough to refrain from lying when required to plead specific facts. Depending on the number of lawyers so inclined, a strict pleading rule could generate benefits by inducing socially desirable prefiling investigations in the mixed equilibrium.

Second, all lawyers, ethical and unethical alike, run a risk of being revealed as uninformed whenever they lie. The defendant knows the true facts, and therefore is more likely than in the informed-plaintiff model to spot fabricated allegations and infer that the plaintiff has not investigated. This might reduce frivolous suit problems signifi-

${ }^{214}$ This can be seen technically by examining the equilibrium results in Part II.B of the Appendix. The filing cost $\left(c_{F}\right)$ does not appear in the formula for $\delta$. Moreover, the $c_{F}$ in the formula for $\sigma$ represents filing costs for a frivolous plaintiff, which are unaffected by a strict pleading rule.

${ }^{215}$ Katz models a strict pleading rule in this way, but he assumes-unrealistically, I believe-that the shift increases filing costs for frivolous as well as legitimate plaintiffs. See Katz, supra note 17, at 16-17 (stating that a stricter pleading rule would "increase costs in all suits").

${ }^{216}$ Although I will not do the technical analysis here, it can be shown that the shift leaves private litigation costs unchanged (the beneficial effect of fewer frivolous filings just offsets the detrimental effect of more trials), but increases public costs, so long as the public cost of discovery and trial far exceeds the public cost of processing a frivolous filing. 
cantly, but only if the obstacles to successful deception are so high that inferences are possible much of the time. ${ }^{217}$

As a result, strict pleading has some potential benefits, at least in the informed-defendant cases. At the same time, however, it is likely to generate substantial costs. A strict pleading rule invites motions to dismiss, and litigating those motions increases administrative costs. In addition, such a rule risks screening out meritorious cases when investigation costs are too high for plaintiffs to obtain the necessary information before filing. ${ }^{218}$

On balance, therefore, the case for strict pleading is much weaker than commonly supposed. The device has some chance of producing substantial benefits only in the informed-defendant cases, and even in those cases the benefits are probably limited and the costs potentially quite high. If the approach is used at all, it should be confined to those litigation settings involving informed defendants and moderate investigation costs.

\section{Penalties}

Penalties are the most popular device for deterring frivolous suits. Rule 11 uses a penalty approach, as do state analogues to Rule 11 . The problem with penalties, however, is similar to the problem with strict pleading: penalties have limited benefits and potentially high costs.

Benefits are limited because of constraints on the size of the feasible penalty. Risk of error at the penalty stage means that meritorious plaintiffs will sometimes have to pay the penalty, and this reduces their expected value of suit. For a given error risk, even a relatively small penalty can turn weak, but still meritorious, cases into negative expected value suits at the margin. As the penalty amount rises, the chilling effect spreads to stronger and stronger cases. Moreover, the effect at any given penalty level will be greater for risk-

${ }^{217}$ To confirm this, we would have to solve a different model, one in which the defendant always knows whether the plaintiff has investigated. It is worth mentioning that these benefits are achieved only for lawsuits in the mixed equilibrium. In particular, insofar as we are concerned about suits in the filing equilibrium, see supra note 133 and accompanying text, we get no help whatsoever from this signaling effect: all plaintiffs still file without investigating and meritless suits still produce the same high costs.

${ }^{218}$ One such group of meritorious cases subject to screening includes those cases that belong to the filing equilibrium of the informed-defendant model. See supra notes $119-28$ and accompanying text. 
averse plaintiffs, since the prospect of a substantial penalty adds riskbearing costs to the litigation. ${ }^{2}$

Moral principles of proportionality can also limit the penalty amount. For example, a meritless suit filed because of a merely negligent failure to investigate probably deserves a smaller penalty on moral grounds than one filed recklessly or with actual knowledge that suit was meritless. ${ }^{220}$

On the cost side, litigation over penalties can add significantly to administrative expense. ${ }^{221}$ Indeed, critics of 1983 Rule 11 were fond of complaining about the high cost of "satellite litigation" at the sanctions stage. ${ }^{222}$ But there is a puzzle: If litigation over penalties is costly, then settlement of the penalty dispute should be an attractive option. ${ }^{223}$ Since settlement avoids litigation, it also avoids litigation

${ }^{219}$ These risk-bearing costs will persist, and perhaps even increase, if the damage award is adjusted upward to compensate for erroneous penalties, as Professors Polinsky and Rubinfeld recommend. See Polinsky \& Rubinfeld, supra note 60, at 419. 21 (arguing that the damage award can be adjusted upward to offset the reduction in expected value due to erroneous imposition of penalties on legitimate plaintiffs).

${ }_{=00}^{ \pm 0}$ For instance, factors relevant to determining the appropriate sanction under current Rule 11 include "[w] hether the improper conduct was willful, or negligent" and "whether [the filing] was intended to injure." FED. R. CIV. P. 11 advisory committee's note (1993). Moreover, under 1983 Rule 11, courts did not often award huge penalties; they frequently set the penalty amount equal to the opposing party's fees and costs. See Melissa L. Nelken, Has the Chancellor Shot Himself in the Foot? Looking for a Middle Ground on Rule 11 Sanctions, 41 HASTINGS L. J. 383, 399 (1990) (stating that "attorney's fees have . . dominated the sanctions picture under Rule 11"); see also Marshall et al., supra note 12, at 956-58 (mentioning an empirical study which found a median Rule 11 sanction of $\$ 2500$ and $91.3 \%$ of sanctions totalling $\$ 25,000$ or less).

${ }_{221}$ For a useful game-theoretic analysis of the penalty stage that highlights the tradeoff between administrative costs and deterrence benefits, see Polinsky \& Rubinfeld, supra note 60.

${ }_{222}$ See, e.g., Schwarzer, supra note 189, at 1018 (stating that excessive satellite litigation "results from [Rule 11's] inherent unpredictability and the readiness of lawyers to resort to any device available to exert pressure on their opponents"); Carl Tobias, The 1993 Revision of Rule 11, 70 IND. L.J. 171, 172-73 (1994) (stating that 1983 Rule 11 created expensive and undesirable litigation over the appropriateness of sanctions). It is also worth noting that pervasive satellite litigation might have been primarily a transitional problem under 1983 Rule 11-the result of judicial and litigant uncertainty about the new Rule's application. If so, then administrative costs might not be as high as many claim. See Tobias, supra, at $\mathbf{1 7 4 - 7 5}$ (noting that the quantity of satellite litigation declined as federal judges became more consistent in applying Rule 11); see also Marshall et al., supra note 12, at 958 (empirical study reporting relatively little attorney time spent on Rule 11 matters).

${ }_{223}$ Polinsky and Rubinfeld ignore the settlement possibility in their analysis of Rule 11 sanctions, see Polinsky \& Rubinfeld, supra note 60, and I am aware of no other work that addresses the point. But of. Georgene M. Vairo, Commentary, Rule 11: Where We Are and Where We Are Going, 60 FORDHAM L. REv. 475, 482 (1991) (suggesting that 
costs. Therefore, if administrative costs are high at the penalty stage, there must be a serious impediment to settlement. ${ }^{224}$

One possible impediment is informational asymmetry. If one party has private information at the penalty stage, even after pretrial opportunities for fact-gathering, the residual informational asymmetry could make settlement difficult. ${ }^{225}$ A potentially more significant factor, however, is the reputational effect of penalties. Defendants benefit from official declarations of frivolousness-and so they have incentives to litigate-insofar as a clear judicial signal of attorney reputation facilitates formation of a reputation market. ${ }^{226}$ Moreover, lawyers for plaintiffs in meritorious suits also have incentives to litigate. A lawyer who is falsely accused of filing a frivolous suit faces a potentially serious harm to her reputation. ${ }^{227}$ She might be inclined to settle if settlement guaranteed complete secrecy, but secrecy is hard to achieve. For instance, it would be difficult to conceal the facts from friends and colleagues in the same firm, ${ }^{228}$ and there is always a risk that news of a settlement will spread to the wider legal community. Given this, a lawyer might reasonably prefer to take a chance

1983 Rule 11 might have exacerbated the level of contentiousness, which interfered with settlement of the main action even when attorneys might otherwise have been inclined to settle to avoid sanctions).

${ }^{224}$ An alternative possibility is that judges frequently impose penalties on their own motion without allowing settlement.

${ }^{223}$ See generally COOTER \& ULEN, supra note 200, at 48487 (discussing the effects of informational asymmetry on settlement). In the informed-plaintiff model, the defendant always knows the suit is frivolous when the plaintiff drops, so there can be no informational asymmetry. In practice, however, a decision to drop is not likely to communicate such a clear message. In the informed-defendant model, the defendant knows whether the suit is meritless, but she does not necessarily know whether (or how much) the plaintiff has investigated, and this can create an informational asymmetry.

Judges sometimes recount the history of an attorney's litigation conduct when deciding on a Rule 11 sanction. See, e.g., Blancato v. Saint Mary Hosp., No. CIV.A.914114, 1993 WL 273687, at ${ }^{\circ}$-5 (E.D. Pa. July 21, 1993); see also FED. R. Crv. P. 11 advisory committee's note (1993) (noting that one factor relevant to deciding the appropriate sanction is "whether the person has engaged in similar conduct in other litigation"). This kind of summary can be an effective vehicle for publicizing attorney reputation.

${ }^{227}$ See, e.g., FDIC v. Tekfen Constr. \& Installation Co., 847 F.2d 440, 444 (7th Cir. 1988) (noting the importance of stigma); Marshall et al., supra note 12, at 957 (hypothesizing that much of the bar's resistance to Rule 11 may be due to the stigmatizing effect of the penalty); Neil H. Klausner, Note, The Dynamics of Rule 11: Preventing Frivolous Litigation by Demanding Professional Responsibility, 61 N.Y.U. L. REV. 300, 330 (1986) (noting that stigma alone can be an effective deterrent).

${ }^{228}$ Especially if the defendant can also seek a penalty from the firm on a joint liability theory. See FED. R. CrV. P. 11(c)(1)(A). 
with litigation, and eventual vindication, than to settle the penalty dispute. $^{229}$ As a result, litigation costs could be high at the penalty stage.

These benefits and costs balance out a bit differently in the informed-plaintiff and the informed-defendant models. To achieve substantial deterrence in the informed-plaintiff model, the penalty must be set so high that it is likely to trigger proportionality problems and produce high error and administrative costs, especially with the strong reputation risk that attaches to a knowingly frivolous filing. ${ }^{230}$ In the informed-defendant model, on the other hand, only a modest penalty is needed, at least in theory, to deter all frivolous plaintiffs. ${ }^{231}$ A modest penalty is likely to create less of a chilling effect on meritorious plaintiffs and lower reputation obstacles to settlement. At the same time, however, even a modest penalty can still deter a large number of meritorious suits, and informational asymmetries as well as residual reputation risks can still scuttle settlement.

Thus, the choice of a penalty system involves a much more complicated cost-benefit balance than is commonly supposed. Penalties are more strongly justified in informed-defendant cases, but even there the possibility of high costs cannot be ignored. Indeed, it might be best to implement a penalty approach only sparingly, especially if

Ones observes similar behavior from doctors, who sometimes insist on litigating medical malpractice suits to avoid harm to reputation and self-esteem. See Gross \& Syverud, supra note 124, at 366 (stating that doctors often go to trial in malpractice suits for "the opportunity for vindication"); of. Syverud, supra note 74, at 1159 (discussing the effect of harm to reputation from lawsuits in other vocational contexts).

${ }^{230}$ See Katz, supra note 17 , at 20 (noting the high costs). This outcome is difficult to demonstrate intuitively, but a numerical example might help. Recall our John and Mary hypothetical. See supra Part V.A.l. There we assumed an $80 \%$ win rate for legitimate plaintiffs, an average verdict of $\$ 50,000$, a filing cost of $\$ 1000$, and litigation costs of $\$ 10,000$ for each side. Assuming that $50 \%$ of potential suits are frivolous, a penalty set as high as the defendant's total litigation costs $(\$ 10,000)$ still results in $50 \%$ of potential frivolous suits being filed (compared to $67 \%$ without a penalty) and $72 \%$ of legitimate suits being tried.

231 It can be shown with some mathematics that in the informed-defendant model all frivolous plaintiffs are deterred from suing by a penalty equal to the defendant's discovery costs. This penalty, in effect, forces all suits out of the mixed and into the investigation equilibrium by raising the cutoff that separates the two equilibria. By contrast, it is not possible, even in theory, to deter all frivolous filings in the informedplaintiff model. The frequency of frivolous filings declines gradually, but never reaches zero, as the size of the penalty increases. See Katz, supra note 17, at 19-20 (noting that an infinitely high deposit or penalty would be required in order to deter absolutely all strike suits). 
private parties can create a penalty system on their own through the use of a bonding device. ${ }^{252}$

\section{A More Promising Approach: Judicial Screening}

There is another approach that has more promise than strict pleading or penalties: early judicial screening of frivolous suits based on a preliminary review of the merits. Currently, courts screen civil rights cases by granting early summary judgment on qualified immunity, sometimes after permitting narrow discovery focused on the immunity issue. ${ }^{233}$ Unfortunately, however, the idea of early screening has not been widely accepted.

My proposal implements the screening approach, but in a different way than in the civil rights cases. The approach has three components. First, plaintiff must submit evidence in the form of affida-

232 See supra text accompanying notes 16472. One could make an exception for those extreme situations where frivolousness is transparently clear. These include cases in which the plaintiff's attorney plainly knows the suit is meritless, as well as cases in which the attorney does little or no investigation despite ready access to public information. See, e.g., Johnson v. A.W. Chesterton Co., 18 F.3d 1362, 1366 (7th Cir. 1994) (referring to the lawsuit as a "gamble" and the attorney's conduct as "reckless willingness" to impose burdens on others). The administrative and error costs are likely to be low when frivolousness is easy to verify, and the intentionality or extreme recklessness of the conduct might support a penalty on moral grounds. At the same time, however, it is important to confine this category to the most extreme cases and to define its contours as clearly as possible to minimize costs.

${ }_{233}$ See Crawford-El v. Britton, 93 F.3d 813, 819 (D.C. Cir. 1996) (holding that a plaintiff alleging illicit motive in a civil rights case where defendant has a qualified immunity defense must offer "specific, nonconclusory assertions of evidence" supporting motive in order to avoid early summary judgment prior to discovery); Elliott v. Thomas, 937 F.2d 338, $344-45$ (7th Cir. 1991) (holding that plaintiffs must produce evidence of illicit motive to avoid early summary judgment in a civil rights case where motive is an issue and qualified immunity is a defense); Blum, supra note 4 , at $92-95$ (stating that under Rule 56(f), plaintiffs can move for discovery to acquire information necessary to defend a summary judgment motion, but that "the court could limit such discovery to matters related to the qualified immunity issue"); Eric $\mathrm{H}$. Cottrell, Note, Civil Rights Plaintiffs, Clogged Courts, and the Federal Rules of Civil Procedure: The Supreme Court Takes a Look at Heightened Pleading Standards in Leatherman v. Tarrant County Narcotics Intelligence \& Coordination Unit, 72 N.C. L. REV. 1085, 1110-11 (1994) (proposing early summary judgment to screen out frivolous civil rights cases); see also Lapham, supra note 138, at 281-88 (recommending a similar approach more generally through a modification of Rule 56(f)). Moreover, some states screen medical malpractice cases, but this screening method relies on panel rather than judicial review and penalties rather than dismissal. See Jean A. Macchiaroli, Medical Malpractice Screening Panels: Proposed Model Legislation to Cure Judicial Ills, 58 GEO. WASH. L. REV. 181, 18897, 239-51 (1990) (reviewing current medical malpractice screening panels and proposing a model statute). 
vits, documents and the like supporting the allegations of his complaint. Second, if for some reason plaintiff cannot make the necessary evidentiary submission, he must file an affidavit detailing the investigatory steps he has taken before filing, the reasons why he has not investigated further, and the reasons why he believes that probative evidence might be obtained through discovery. ${ }^{234}$ Third, before plaintiff can litigate past the filing stage, the trial judge must determine whether the suit has merit based on plaintiff's submissions. This determination is not the same as a summary judgment. The purpose is to ascertain whether the minimal requirements of Rule 11 are satisfied, not whether a reasonable jury could find for the plaintiff.

If the plaintiff does not submit evidence or an explanatory affidavit, then defendant can obtain dismissal for failure to state a claim. Moreover, dismissal is also warranted if the trial judge determines that the suit is meritless based on either the evidence or the inadequacy of the plaintiff's prefiling investigation. If, however, the plaintiff persuades the judge of the adequacy of his investigation and his need for discovery, the judge may either permit the suit to go forward in the normal course, or review submissions a second time after allowing limited discovery.

This description, although not a precise blueprint, is sufficient to show the advantages of screening over other devices. For instance, lying is a much less serious problem for screening than for strict pleading, because the plaintiff must submit evidence-not just allegations. $^{235}$

Furthermore, satellite litigation is likely to generate lower costs here than in a penalty system. There might be more cases to review, but only if defendants challenge submissions more frequently than they seek penalties. Even so, most of these cases should be quite easy to review given the limited scope of the decision. In addition, be-

${ }^{234}$ In some respects, this resembles the affidavit a party now files under Rule 56(f) to postpone summary judgment until after discovery, except that the $56(f)$ affidavit does not focus on prefiling investigation. See FED. R. CIV. P. 56(f); see also Lapham, supra note 138, at 267-81 (discussing the requirements of Rule 56(f)).

${ }_{235}$ Of course, screening will not help much if the plaintiff is a blatant liar and is in a position to have personal knowledge of the material facts. Under these circumstances, the plaintiff can avoid being screened out simply by filing her own affidavit and lying under oath. However, this extreme situation is very difficult to handle under any approach. Neither a strict pleading nor a penalty system is likely to do any better than screening. 
cause there is no risk of a stigmatizing penalty and no need to find bad faith, the trial judge has more power to limit hearing opportunities in order to control costs. ${ }^{236}$ Moreover, the salient issues focus narrowly on the adequacy of plaintiff's submission rather than ranging broadly over the merits of plaintiff's case. ${ }^{237}$ Finally, parties are not likely to litigate as strenuously because screening does not have the same implications for reputation, and the risk of erroneous dismissal should be relatively low given the limited nature of the screening inquiry. ${ }^{238}$

Conceivably, lawyers will file more frivolous suits when penalties are not a risk, gambling on the chance of making it through the screen. But filing is more costly in a screening system, since lawyers must submit affidavits and verify investigation efforts. With these additional costs, filing will not be very attractive when there is only a slight chance of getting through the screen. Moreover, early judicial screening undermines a frivolous plaintiff's ability to exploit his informational advantage in the informed-plaintiff model and reduces the temptation of defendants in meritorious suits to pool in the informed-defendant model, thereby reducing the frequency of frivolous filings.

One potential risk plagues screening and other devices, such as penalties, which require judicial determinations of frivolousness. A trial judge might abuse the discretion these devices confer by differ-

${ }^{29 r i}$ See Mathews v. Eldridge, 424 U.S. 319, 332-49 (1976) (stating a balancing test for due process notice and hearing requirements); cf. Donaldson v. Clark, 819 F.2d 1551, 1558-61 (11th Cir. 1987) (noting the flexibility of hearing requirements under Rule 11, and reciting factors to consider including the type and severity of the sanction and the necessity of a bad faith finding, and concluding that a hearing is normally not required); Rodgers v. Lincoln Towing Servs., Inc., 771 F.2d 194, 205-06 (7th Cir. 1985) (holding that it was proper to impose Rule 11 sanctions without a hearing where no bad faith was involved and where the judge could easily determine the quality of investigation).

${ }_{237}$ Making the frivolousness determination at a very early stage in the lawsuit should help focus judicial attention on the correct inquiry-what plaintiffs lawyer knew and did prior to filing-and should guard against the temptation to consider the results of later discovery and trial. See FED. R. CrV. P. 11 advisory committee's note (1983) ("The court is expected to avoid using the wisdom of hindsight"); Nelken, supra note 220, at 401-04 (advocating a focus on prefiling conduct); Schwarzer, supra note 189 , at 1021-22 (same).

${ }^{238}$ This is especially so if significant doubts are resolved in plaintiff's favor. $C f$. National Union Fire Ins. Co. v. Continental Ill. Corp., 113 F.R.D. 637, 639 (N.D. Ill. 1987) (noting that "all doubts [should] be resolved in favor of the signer" before imposing Rule 11 sanctions (quoting Eastway Constr. Corp. v. City of New York, 762 F.2d 243, 254 (2d Cir. 1985))). 
entially burdening particular types of litigation, such as civil rights suits, disfavored on substantive grounds. ${ }^{239}$ Such abuse could be particularly troubling in a screening system because screening gives the judge power to stop the suit before it gets underway.

Although this concern is relevant, it does not justify ruling out a screening approach altogether. For one thing, clearer articulation of the standard prohibiting frivolous suits, as part of a tighter Rule 11, should reduce the opportunities for abuse. Clearer standards also make a more searching appellate review possible, which can constrain trial judges. If hard evidence of frequent abuse exists (and I know of none), then the Advisory Committee might consider including an express caution in the Note accompanying the Rule. In the end, if the risk of abuse is substantial and incurable-in which case we have much more to worry about than frivolous suits-it might be better to rely on approaches that give the trial judge less power up front.

\section{CONCLUSION}

Frivolous litigation is a complex phenomenon. It is difficult to define and almost impossible to observe, and it defies all attempts at simple explanation. Indeed, we have no hard empirical evidence bearing on the nature or seriousness of the problem. Yet we continue to regulate.

This Article has shown how game theory might help fill some of the informational gaps. Frivolous litigation is complex because it arises from a complicated interplay of strategic forces. When gametheoretic tools are applied to the problem, they yield a crucial insight: informational asymmetry is likely to be the most significant cause of frivolous suits.

Building on this insight, we have seen the importance of another factor: the direction of the informational asymmetry. When plaintiff has the private information, he can pretend to be legitimate and fool an uninformed defendant. When defendant has the private information, however, the analysis is more complicated: a meritless suit is frivolous only if plaintiff should have investigated, and the gametheoretic analysis helps identify cases that satisfy this condition.

Whether the plaintiff or the defendant has the private informa-

${ }^{239}$ See, e.g., Robert L. Carter, Federal Rules of Civil Procedure as a Vindicator of Civil Rights, 137 U. PA. L. REV. 2179, 2191-95 (1989) (criticizing 1983 Rule 11 on this ground). 
tion, frivolous suits waste litigation costs and induce unjustified wealth transfers. The precise nature and extent of these problems differ according to the direction of the informational asymmetry, but one critically important prediction applies across the board. One of the most serious effects of frivolous litigation is indirect: frivolous suits frustrate settlement of legitimate suits.

We have also seen how a game-theoretic analysis can assist policymaking. The challenge here is to translate the formal results into relatively simple, yet reliable, generalizations suitable for regulatory use, and to do this in a way that is sensitive to the limits of formal analysis. In particular, we derived a workable definition of a reasonable prefiling investigation that clarified the vague mandate in current Rule 11. Moreover, we saw how it is possible to use formal analysis coupled with empirical research to identify particular settings likely to have serious frivolous suit problems justifying enforcement measures. And we also saw how formal results can help in designing an optimal enforcement scheme.

More work is needed, of course. There are other possible information structures to explore. ${ }^{240}$ We also need to examine lawsuits with more complex party structures. Nevertheless, the informedplaintiff and informed-defendant models provide a framework for understanding the basic dynamics driving frivolous suits and a foundation for future work.

From the outset, this Article has had a broader goal: to show that game-theoretic reasoning is a useful and vital tool for procedural analysis. Regulation requires prediction, and prediction in the litigation setting requires an understanding of strategic interaction. Game theory offers deep insight into strategic thinking, and much of this insight can be understood without mathematical sophistication. It is vital that we continue the effort to infuse procedural rulemaking with game-theoretic analysis, tempered by empirical research and widely shared experience. The future of our procedural system may depend on it.

${ }^{240}$ For example, it is possible for both parties to be ignorant of the merits at the time of filing. See, e.g., Albright v. Upjohn Co., 788 F.2d 1217, 1221-22 (6th Cir. 1986) (imposing Rule 11 sanctions on plaintiff's attorney for failure to investigate adequately whether the defendant manufacturer sold the tetracycline that the plaintiff used). It is also possible that even more complex scenarios might be needed to explain some cases. For example, the defendant might know the suit is meritless and also know that the plaintiff knows the suit is meritless, but not know whether the plaintiff knows that the defendant knows. 


\section{APPENDIX}

In this Appendix, I summarize the results of the informed-plaintiff and informed-defendant models in mathematical form. I rely on Professor Avery Katz's work for proofs of the informed-plaintiff results, ${ }^{241}$ and I prove the informed-defendant results in a separate technical paper. ${ }^{242}$

\section{FORMAL NOTATION COMMON TO BOTH MODELS}

r - The background proportion of potential legitimate (meritorious) suits. $1-r$, therefore, is the background proportion of frivolous (meritless) suits.

$\mathrm{p}$ - The probability that a legitimate (meritorious) suit wins on liability at trial.

x - The expected trial award if a legitimate (meritorious) case wins.

$c_{F}, c_{D}, c_{T}-$ Plaintiff's costs of filing suit, litigating from the filing stage through discovery, and litigating from the discovery stage through trial, respectively.

c - Plaintiff's total litigation costs;

i.e., $c=c_{F}+c_{D}+c_{T}$.

$d_{D}, d_{T}$ - Defendant's costs of litigating the case through discovery, and from the discovery stage through trial, respectively.

d - Defendant's total litigation costs;

$$
\text { i.e., } d=d_{b}+d_{r} \text {. }
$$

\section{THE INFORMED-PLAINTIFF MODEL}

Assuming $\mathrm{px}-\mathrm{c}>0$, so all legitimate plaintiffs sue, the following results obtain in equilibrium:

A. If $r>\left(p x-c_{D}-c_{T}\right) /(p x+d)$ :

- All defendants offer $\mathrm{px}-\mathrm{c}_{\mathrm{D}}-\mathrm{c}_{\mathrm{T}}$.

242 See Bone, supra note 122. 
- All frivolous plaintiffs sue.

- All plaintiffs accept the settlement offer.

B. If $r<\left(p x-c_{D}-c_{T}\right) /(p x+d)$ :

- Defendants offer $p x-c_{D}-c_{T}$ with probability $\sigma$ and refuse to settle with probability $1-\sigma$, where:

$$
\sigma=c_{F} /\left(\mathrm{px}-\mathrm{c}_{\mathrm{D}}-\mathrm{c}_{\mathrm{T}}\right) \text {. }
$$

- Frivolous plaintiffs sue with probability $\delta$, where:

$$
\delta=\left[r\left(c_{D}+c_{T}+d\right)\right] /\left[(1-r)\left(p x-c_{D}-c_{T}\right)\right] .
$$

- All plaintiffs accept an offer of $p x-c_{D}-c_{r}$.

- If the defendant refuses to settle, legitimate plaintiffs still litigate, but frivolous plaintiffs drop.

\section{THE INFORMED-DEFENDANT MODEL}

Assuming $\mathrm{px}-\mathrm{c}>0$ and letting $\mathrm{b}$ denote the cost of a prefiling investigation, the following results hold in equilibrium: ${ }^{243}$

A. If $r<c_{F} /\left(p x-c_{D}-c_{T}\right)$ :

1. And $b<r(p x-c)$ : The same Investigation Equilibrium as in D.1 below.

2. And $b>r(p x-c)$ : Plaintiffs never investigate and never sue.

B. If $c_{F} /\left(p x-c_{D}-c_{T}\right)<r<\left(c_{F}+c_{D}\right) /\left(p x-c_{T}\right)$ :

1. And $b<(1-r) c_{F}$ : The same Investigation Equilibrium as in D.1 below.

2. And $b>r(p x-c)$ : Plaintiffs never investigate and never sue.

3. And $(1-r) c_{F}<b<r(p x-c)$ : The same Mixed Equilibrium as in D.3 below.

${ }^{243}$ A technical point deserves brief mention here. The reader versed in game theory will note that some of the equilibria described in this section can exist only for particular beliefs off the equilibrium path. See generally RASMUSEN, supra note 18, at 143-52 (discussing the importance of out-of-equilibrium beliefs). In my technical paper, I specify out-of-equilibrium beliefs in a plausible way, using passive conjectures and a simple version of the intuitive criterion. See Bone, supra note 122 , at $15-18, \mathrm{nn}$. 21-23 (noting the possible effects of strategies and beliefs that are off the equilibrium path). 
C. If $\left(c_{F}+c_{D}\right) /\left(p x-c_{T}\right)<r<\left(c_{D}+d_{D}\right) /\left(p x-c_{T}\right)$ :

1. And $b<(1-r) c_{F}$ : The same Investigation Equilibrium as in D.1 below.

2. And $b>(1-r)\left(c_{F}+c_{D}\right)$ :

- Plaintiffs never investigate and always sue.

- Defendants always offer $r\left(p x-c_{T}\right)-c_{D}$ whether the suit is meritorious or meritless.

- Plaintiffs always accept.

3. And $(1-r) c_{F}<b<(1-r)\left(c_{F}+c_{D}\right)$ : The same Mixed Equilibrium as in $\mathrm{D} .3$ below.

D. If $r>\left(c_{D}+d_{D}\right) /\left(p x-c_{T}\right)$ : (These are the three equilibria discussed in Part IV.B of the text)

1. And $b<(1-r) c_{F}$-Investigation Equilibrium

a. Equilibrium:

- Plaintiffs always investigate.

- No meritless suits are filed.

- Defendants always offer $p x-c_{D}-c_{T}$ in meritorious suits.

- Meritorious plaintiffs always accept.

b. Results:

Private litigation costs (LC) are:

$$
\mathrm{LC}=\mathrm{b}+\mathrm{rc}_{\mathrm{F}} .
$$

Plaintiff's ex ante expected value of suit (EV) is:

$$
\mathrm{EV}=\mathrm{r}(\mathrm{px}-\mathrm{c})-\mathrm{b}
$$

Defendant's ex ante expected loss (EL) is:

$$
E L=r\left(p x-c_{D}-c_{T}\right) \text {. }
$$

2. And $b>(1-r)\left(c_{F}+c_{D}\right)$-Filing Equilibrium

a. Equilibrium:

- Plaintiffs never investigate and always sue.

- In meritorious suits, defendants offer $\mathrm{px}-\mathrm{c}_{\mathrm{D}}-\mathrm{c}_{\mathrm{T}}$ with probability $\tau$, and refuse to settle with probability $1-\tau$, where:

$$
\tau=\left[\mathrm{r}\left(\mathrm{px}-\mathrm{c}_{\mathrm{T}}\right)-\mathrm{c}_{\mathrm{D}}\right] / \mathrm{r}\left(\mathrm{px}-\mathrm{c}_{\mathrm{T}}-\mathrm{c}_{\mathrm{D}}\right) .
$$

- Defendants always refuse to settle meritless suits.

- Plaintiffs always accept an offer of $\mathrm{px}-c_{D}-c_{T}$.

- Plaintiffs drop with probability $B$ in response to a re- 
fusal to settle and litigate with probability $1-B$, where:

$$
B=\left(c_{D}+c_{T}+d\right) /(p x+d) \text {. }
$$

b. Results:

$$
\begin{aligned}
& \mathrm{LC}=c_{F}+(1-r) c_{D}+(1-r) d_{D}\left(p x-c_{D}-c_{r}\right) /(p x+d) . \\
& E V=r(p x-c)-(1-r)\left(c_{F}+c_{D}\right) . \\
& E L=r\left(p x-c_{D}-c_{T}\right)+(1-r) d_{D}\left(p x-c_{D}-c_{T}\right) /(p x+d) .
\end{aligned}
$$

3. And $(1-r) c_{F}<b<(1-r)\left(c_{F}+c_{D}\right)$-Mixed Equilibrium

a. Equilibrium:

- Plaintiffs investigate before filing with probability $\theta$ and do not investigate with probability $1-\theta$, where:

$$
\theta=\left(\mathrm{px}-\mathrm{c}_{\mathrm{p}}-\mathrm{c}_{\mathrm{T}}\right) /(\mathrm{px}+\mathrm{d}) \text {. }
$$

- Plaintiffs who investigate sue if and only if their suits are meritorious. Plaintiffs who do not investigate always sue.

- In meritorious suits, defendants offer $p x-c_{D}-c_{T}$ with probability $\tau$, and refuse to settle with probability $1-\tau$, where:

$$
\tau=\left[r\left(p x-c_{D}-c_{T}\right)+(1-r) c_{F}-b\right] / r\left(p x-c_{D}-c_{T}\right) .
$$

- Defendants always refuse to settle meritless suits.

- Plaintiffs always accept an offer of $\mathrm{px}-\mathrm{c}_{\mathrm{D}}-\mathrm{c}_{\mathrm{T}}$, and always drop when they have not investigated and defendant refuses to settle.

b. Results:

$$
\begin{aligned}
& L C=b+r c_{F} . \\
& E V=r(p x-c)-b . \\
& E L=r\left(p x-c_{D}-c_{r}\right) .
\end{aligned}
$$

\section{CALCULATIONS FOR EXAMPLES}

\section{A. The John v. Mary Hypothetical}

In the text, I use a slip-and-fall hypothetical involving John and Mary to illustrate the intuition behind the informed-plaintiff model. The critical variables have the following values in the hypothetical: $\mathrm{p}=0.8, \mathrm{x}=50,000, \mathrm{c}_{\mathrm{F}}=1000$, and $\mathrm{c}_{\mathrm{D}}+\mathrm{c}_{\mathrm{T}}=\mathrm{d}_{\mathrm{D}}+\mathrm{d}_{\mathrm{T}}=10,000$.

From Part II of this Appendix, we know that the critical value of $r$ separating the two equilibria in the informed-plaintiff model is: $r=\left(p x-c_{D}-c_{T}\right) /(p x+d)$. Substituting the numerical values for the 
variables in this expression, we get:

$$
r=(0.8 \times 50,000-10,000) /(0.8 \times 50,000+10,000)=0.6 .
$$

It follows that when $r>0.6$-or equivalently, when the fraction of potential frivolous suits is less than $40 \%$-all frivolous plaintiffs sue in equilibrium; all defendants offer $\mathrm{px}-\mathrm{c}_{\mathrm{D}}-\mathrm{c}_{\mathrm{T}}$, and all plaintiffs accept the offer. Similarly, when $r<0.6$ - or equivalently, when the fraction of potential frivolous suits is greater than $40 \%$-some frivolous plaintiffs sue in equilibrium, and defendants offer $\mathrm{px}-\mathrm{c}_{\mathrm{D}}-\mathrm{c}_{\mathrm{T}}$ only some of the time.

In footnote 94 of the text, we assumed that $r=0.5$, so the second equilibrium holds. Part II.B of this Appendix gives expressions for $\sigma$ (the frequency of $\mathrm{px}-\mathrm{C}_{\mathrm{D}}-\mathrm{C}_{\mathrm{T}}$ offers) and $\delta$ (the frequency of frivolous filings) in this equilibrium. Substituting the numerical values for the corresponding variables in these expressions, we get:

$$
\begin{gathered}
\sigma=1000 /(0.8 \times 50,000-10,000)=1 / 30 \\
\delta=[0.5 \times 20,000] /[0.5 \times(0.8 \times 50,000-10,000)]=2 / 3 .
\end{gathered}
$$

Therefore, frivolous plaintiffs sue $2 / 3$, or about $67 \%$, of the time, and defendants offer $\$ 30,000$ in $1 / 30$, or about $3 \%$, of the cases. It follows that legitimate plaintiffs settle about $3 \%$ of the time and go to trial about $97 \%$ of the time-as footnote 94 states.

\section{B. The Paul v. Susan Hypothetical}

In the text, I use a medical malpractice hypothetical involving Paul and Susan to illustrate the intuition behind the informed-defendant model. The values of the critical variables in this hypothetical are: $r=0.5, p=0.8, x=50,000, c_{F}=1000$, and $c_{D}=c_{r}=d_{D}=d_{T}=5,000$.

The condition for the three equilibria described in Part III.D of this Appendix is: $r>\left(c_{D}+d_{D}\right) /\left(p x-c_{T}\right)$. Substituting the numerical values, the righthand side of this inequality is:

$$
(5000+5000) /(0.8 \times 50,000-5000)=2 / 7 .
$$

With $r=0.5$, the condition is satisfied.

1. Scenario \#1: $b=100$ 
An investigation costs $\$ 100$ in Scenario \#1, so $b=100$. Substituting the numerical values, we have:

$$
(1-r) C_{F}=0.5 \times 1000=500 .
$$

Therefore, $b<(1-r) c_{F}$, and the investigation equilibrium holds.

\section{Scenario \#2: $b=5000$}

In Scenario \#2, an investigation costs $\$ 5000$, so $b=5000$. Since $(1-r)\left(c_{F}+c_{D}\right)=0.5 \times(1000+5000)=3000$, the condition for the filing equilibrium holds: $b>(1-r)\left(c_{F}+c_{D}\right)$. Part III.D.2 of this Appendix gives expressions for $\tau$ (the rate of $\mathrm{px}-\mathrm{C}_{\mathrm{D}}-\mathrm{C}_{\mathrm{T}}$ offers in meritorious suits) and $B$ (the frequency with which plaintiffs drop when defendants refuse to settle). Substituting the numerical values for the corresponding variables in these expressions, we get:

$$
\begin{aligned}
& \tau=[0.5 \times(0.8 \times 50,000-5000)-5000] / 0.5 \times(0.8 \times 50,000-10,000) \\
& =5 / 6 \\
& B=20,000 /(0.8 \times 50,000+10,000)=2 / 5 \text {. }
\end{aligned}
$$

Therefore, defendants offer $\$ 30,000$ in $5 / 6$, or about $83 \%$, of the meritorious cases, and plaintiffs drop $2 / 5$, or $40 \%$, of the time when defendants refuse to settle. As a result, meritorious plaintiffs drop $1 / 6 \times 2 / 5=1 / 15$, or about $7 \%$, of their suits. Moreover, plaintiffs litigate $3 / 5$ of the meritless suits all the way through discovery.

\section{Scenario \#3: $b=2000$}

An investigation costs $\$ 2000$ in Scenario \#3, so $b=2000$. This value of $b$ falls within the range that supports a mixed equilibrium (i.e., $500<2000<3000$ ). Part III.D.3 of this Appendix gives expressions for $\theta$ (the rate of prefiling investigation) and $\tau$ (the rate of $\mathrm{px}$ $c_{D}-c_{T}$ offers in meritorious suits). Substituting the numerical values for the corresponding variables in these expressions, we get:

$$
\begin{gathered}
Q=(0.8 \times 50,000-10,000) /(0.8 \times 50,000+10,000)=3 / 5 \\
\tau=[0.5 \times(0.8 \times 50,000-10,000)+0.5 \times 1000-2000] /[0.5(0.8 \times \\
50,000-10,000)]=9 / 10 .
\end{gathered}
$$

Therefore, plaintiffs investigate $3 / 5$, or $60 \%$, of the time, and de- 
fendants offer $\$ 30,000$ in $9 / 10$, or $90 \%$, of the meritorious cases and refuse to settle $10 \%$ of those cases. Because the plaintiff files a meritless suit whenever he is uninformed, it follows that $40 \%$ of all meritless suits are filed. Moreover, when defendants refuse to settle, those plaintiffs who have investigated go to trial and those who have not drop their suits. Therefore, $6 \%$ of all meritorious cases go to trial (i.e., a $10 \%$ settlement refusal rate multiplied by a $60 \%$ investigation rate), and $4 \%$ are dropped.

\section{Modified Hypothetical}

\section{a. Footnote 115}

In footnote 115 , I change the numerical values to show how serious a problem the mixed equilibrium can create. In the modified hypothetical, $r=0.4, p=0.6, x=200,000, c_{F}=1000, c_{D}=19,000$, $C_{T}=20,000$, and $d_{D}=d_{T}=20,000$. Moreover, a prefiling investigation costs $\$ 11,000$; thus, $b=11,000$.

With these new values, the condition for the Part III.D equilibria still holds: $\left(c_{D}+d_{D}\right) /\left(p x-c_{T}\right)=(19,000+20,000) /(0.6 \times 200,000$ $-20,000)=0.39$, and with $\mathrm{r}=0.5, \mathrm{r}>\left(\mathrm{c}_{\mathrm{D}}+\mathrm{d}_{\mathrm{D}}\right) /\left(\mathrm{px}-\mathrm{c}_{\mathrm{r}}\right)$, as the condition requires. Furthermore, with $b=11,000$, the condition for a mixed equilibrium also holds. The new numerical values yield $(1-r) c_{F}=600$ and $(1-r)\left(c_{F}+c_{D}\right)=12,000$; therefore, $b=11,000$ falls between these two extremes, as the mixed equilibrium requires.

Substituting the new numerical values for the corresponding variables in the expressions for $\theta$ and $\tau$, we get:

$$
\begin{gathered}
\theta=(0.6 \times 200,000-39,000) /(0.6 \times 200,000+40,000)=81 / 160 \\
\tau=[0.4 \times(0.6 \times 200,000-39,000)+0.6 \times 1000-11,000] /[0.4(0.6 \times \\
200,000-39,000)]=55 / 81 .
\end{gathered}
$$

Therefore, plaintiffs investigate only $81 / 160$, or only about $50 \%$, of the time. Moreover, defendants offer $\$ 81,000$ in only $55 / 81$, or about $68 \%$, of the meritorious cases and thus refuse to settle $32 \%$ of such cases. As a result, $50 \%$ of all meritless suits are filed; $16 \%$ of all meritorious cases go to trial (i.e., a $32 \%$ settlement refusal rate multiplied by a $50 \%$ investigation rate), and $16 \%$ are dropped. Thus, $32 \%$ of all meritorious cases have problematic outcomes (either going to trial or being dropped) solely because of the existence of meritless suits. 
b. Footnote 135

In footnote 135, I consider what happens in a mixed equilibrium when the expected trial award (px) is increased from $\$ 40,000$, as in the original hypothetical (i.e., $0.8 \times 50,000$ ), to $\$ 90,000$-when all the other variables are held constant.

It is easy to verify that the conditions for the mixed equilibrium still hold when $\mathrm{px}=90,000$. First, $\left(\mathrm{c}_{\mathrm{p}}+\mathrm{d}_{\mathrm{D}}\right) /\left(\mathrm{px}-\mathrm{c}_{\mathrm{T}}\right)=10,000 /(90,000$ $-5000)=2 / 17$, and with $r=0.5$, it is clear that $r>\left(c_{D}+d_{b}\right) /\left(p x-c_{T}\right)$. Second, the increase in $\mathrm{px}$ has no effect on the range for $b$, so with $b=2000$, the cost of investigation still falls between the two extremes of $\$ 500$ and $\$ 3000$.

With $\mathrm{px}=90,000$, the values of $\theta$ and $\tau$ become:

$$
\begin{gathered}
\theta=(90,000-10,000) /(90,000+10,000)=4 / 5 \\
\tau=[0.5 \times(90,000-10,000)+0.5 \times 1000-2000] /[0.5(90,000- \\
10,000)]=77 / 80 .
\end{gathered}
$$

Therefore, while plaintiffs investigate $60 \%$ of the time when the expected trial award is $\$ 40,000$, they investigate $4 / 5$, or $80 \%$, of the time when the expected trial award is $\$ 90,000$. Furthermore, the rate at which plaintiffs drop meritorious suits-which is also the frequency of unjustified wealth transfers-is $1 / 5 \times 3 / 80=3 / 400$, or about $0.8 \%$, when the expected trial award is $\$ 90,000$. This should be compared to $4 \%$ when the expected trial award is $\$ 40,000$. 
